أسباب العقم في الشريعة والطب وحكم

$$
\text { علاجه }
$$

( ) مراسة فقهية مقارنة )

$$
\text { دكتور }
$$

د/ ياسر عبد الحميد النجار

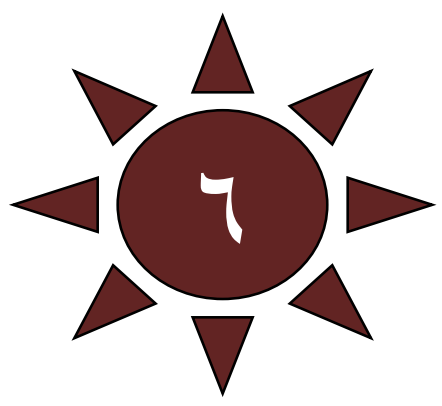

مدرس الفقه المقارن بكلية الشريعة و القانون فرع جامعة

$$
\text { الأزهر بالدقهلية }
$$

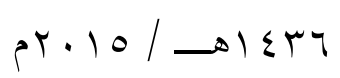

\title{
مق مقاسمة
}

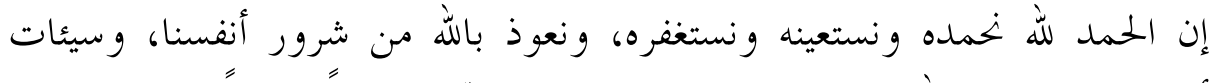

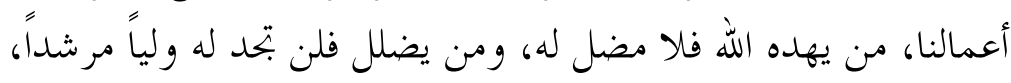

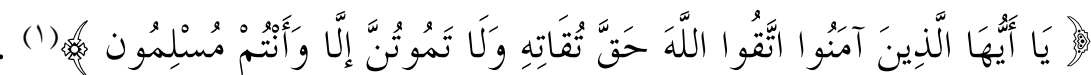

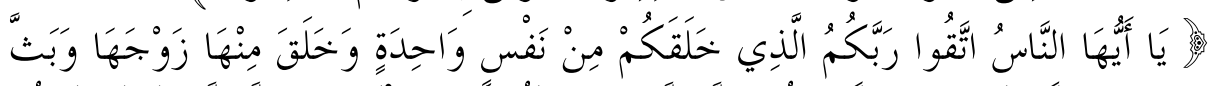

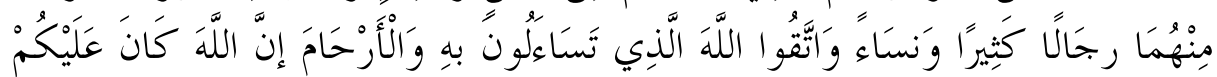

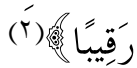

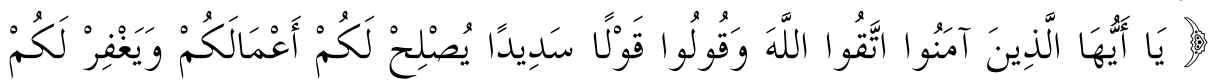

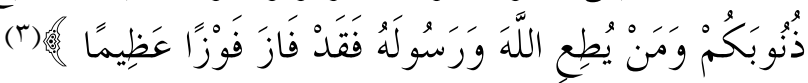

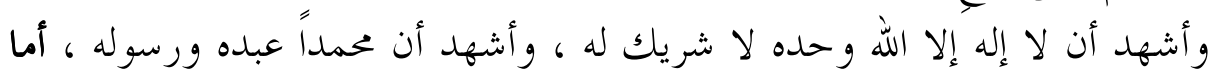

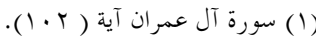

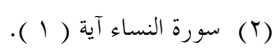

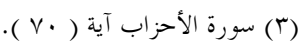

$r \cdot$. 


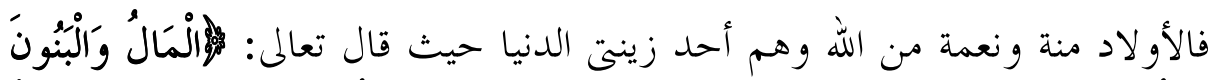

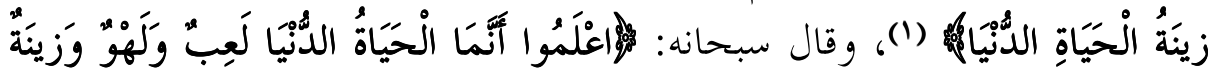

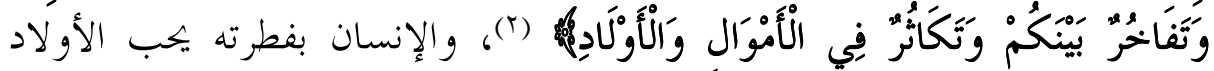

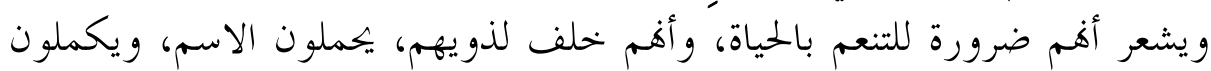

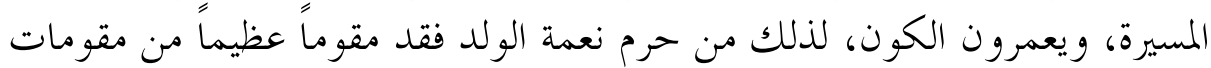

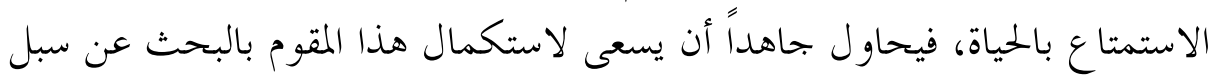

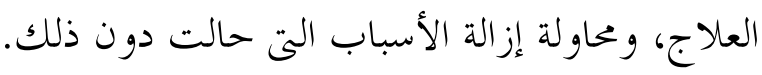

لذا كانت مشكلة العقم مشكلة عويصة فعدد النساء العواقر في أوروبا و الولايات

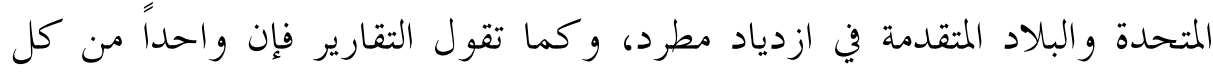
سبعة يعانون من العقم وهم في زمن الإنجاب. وفى تقرير آخر أن ـ أل من الأزواج في سن الإبحاب يعانون من العقم في

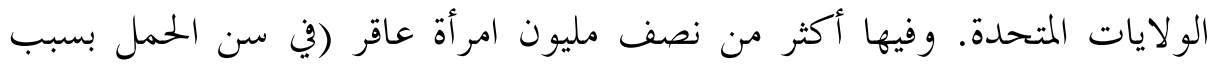

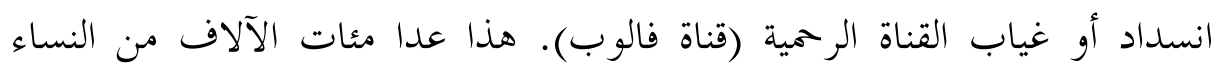

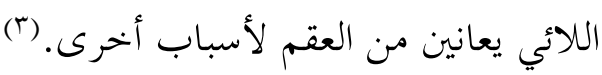

هذه النسب في البلاد المتقدمة فما بالنا بالبلاد الأقل تقدماً، مع حرص هذه البلاد

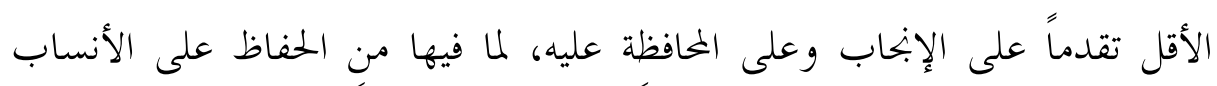

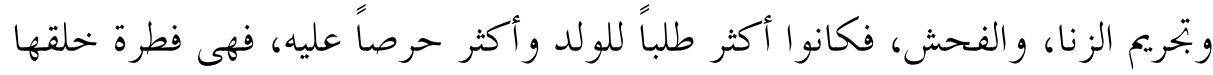

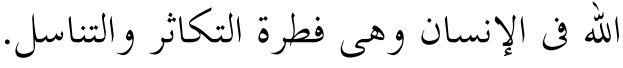

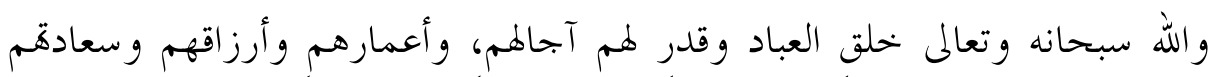

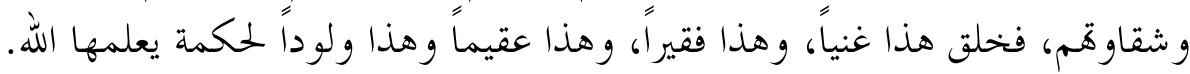

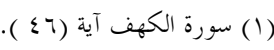

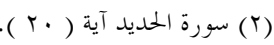

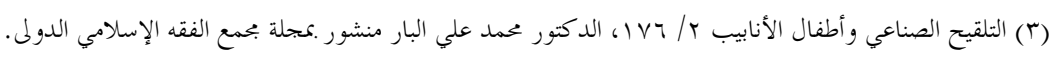




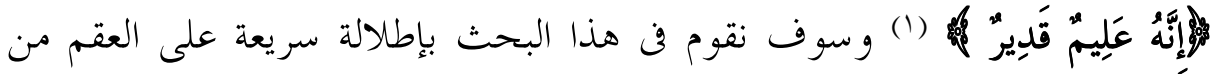

الماهية، والأسباب، والأنواع، وطرق العلاج، ومدى مشروعية التداوى منه في الفقه الإسلامى. سائلاً المولى جل وعلا أن يجنبنا الزلل، ويرزقنا السداد إنه جواد كريم.

وسوف يشتمل هذا البحث على ثلاثة مباحث: المبحث الأول: تعريف العقم، وبيان أنو اعه. المبحث الثانى: أسباب العقم، وطرق علاجه. المبحث الثالث: مشروعية التداوى من العقم. 


\section{المبمث الأول : تعريف العقم وبيان أنهاعه}

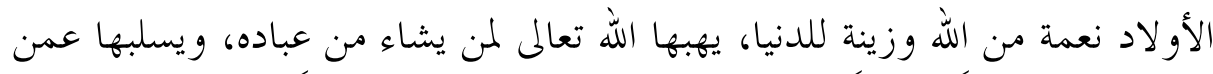

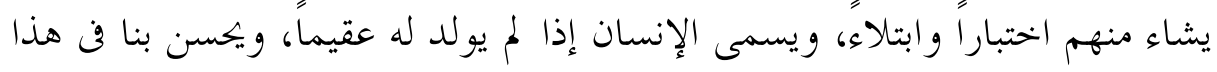

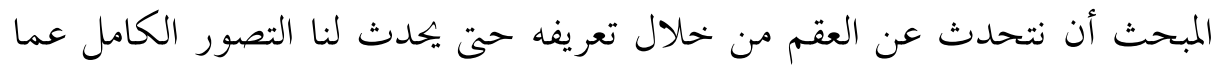

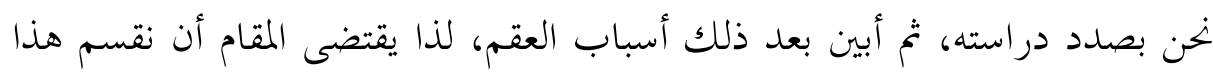

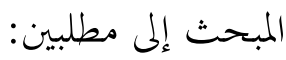

$$
\text { المطلب الأول: تعريف العقم }
$$

\section{( أ ) تعريف العقم لغة :}

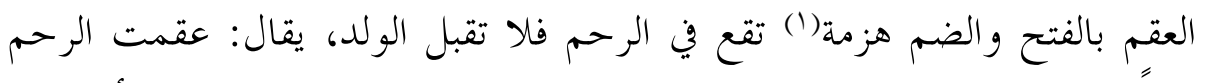

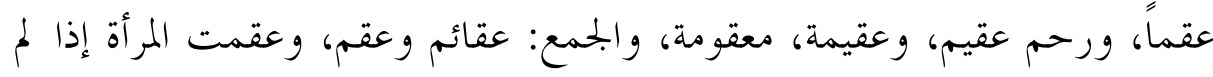

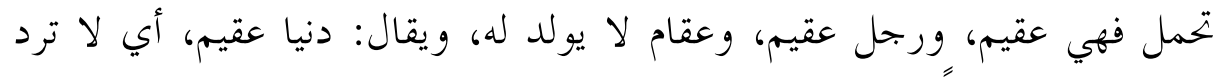

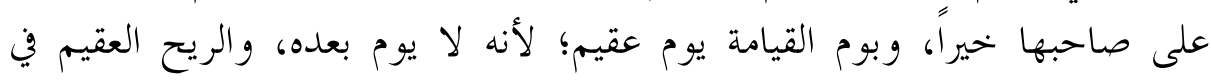

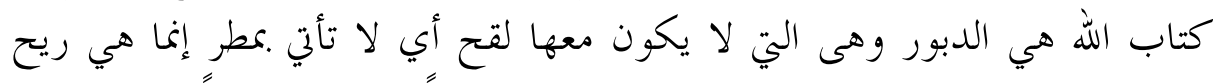

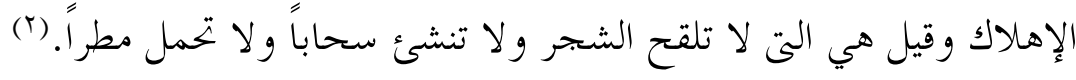

وجاء فن المعجم الوسيط أن العقم "حالة تحول دون التناسل في الذكر والأنثى". (")

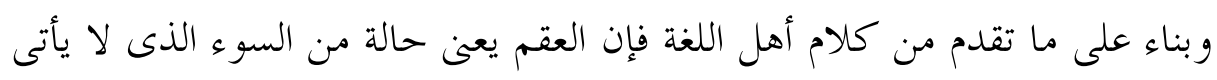

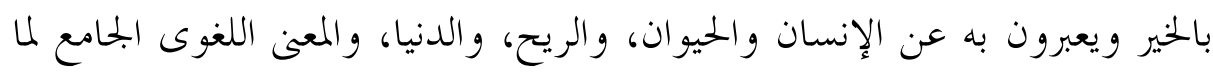

$$
\begin{aligned}
& \text { (1) الهزمة: عدم التماسك، يقال: غيث هزم متهزم متبعق لا يستمسك كأنه متهزم عن مائه وكذلك هزيع السحاب. لسان العرب }
\end{aligned}
$$

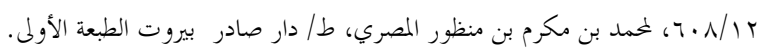

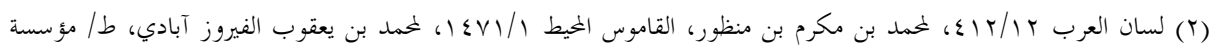

$$
\begin{aligned}
& \text { الرسالة. }
\end{aligned}
$$

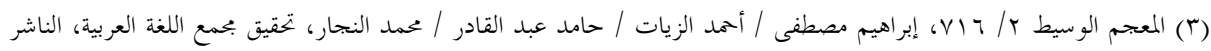

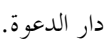


تقدم أن العقم هو عدم القدرة على حمل الخير وهذا التعريف اللغوى قريب من تعريف الأطباء و الفقهاء إذ يعنون به عدم القدرة العدره على على الإبحاب كما سيأتى.

( ب ) تعريف العقر والفرق بينه وبين العقم

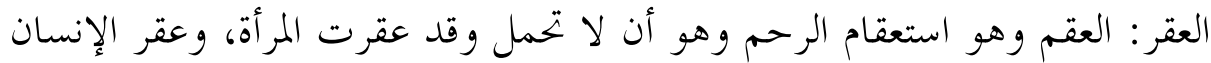

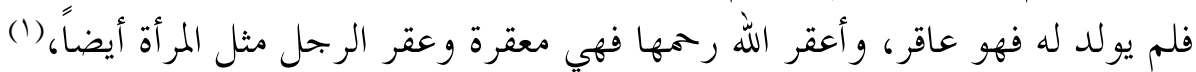

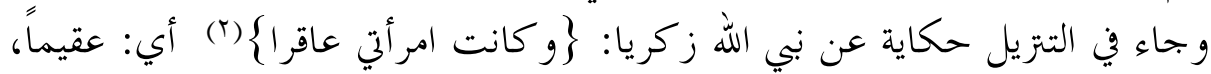

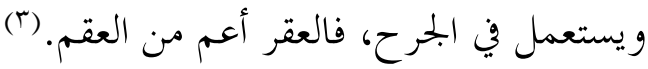

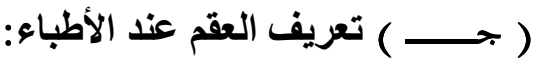

عرف الأطباء حالة العقم بأها:

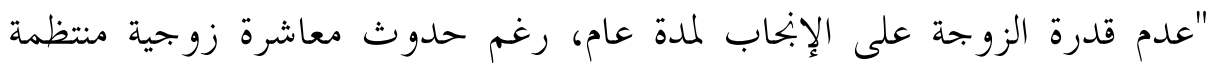

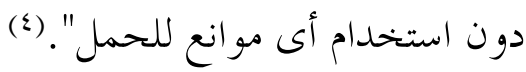
وقيل هو: "عدم القدرة على الإبجاب". (0) وقيل هو: " عبارة عن عدم إبحاب كل أنثى ناضجة ومكتملة في مرحلة إبحاب

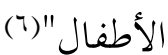

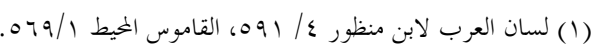

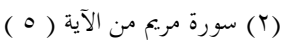

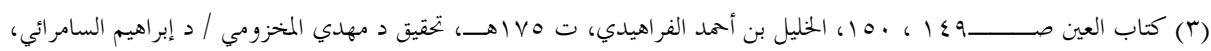

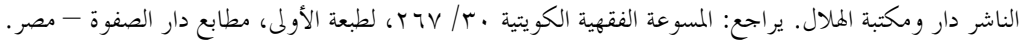

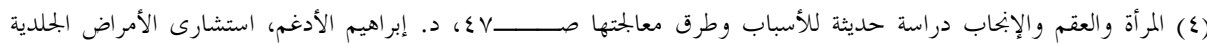

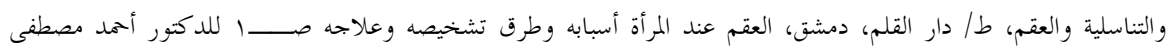

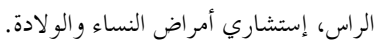

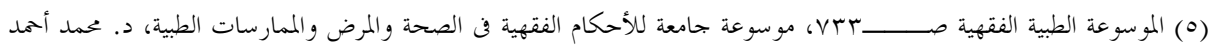
كنعان. ط/ دار النفائس.

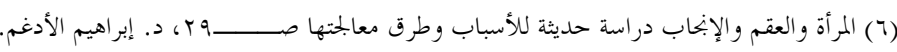


والملاحظ أن الأطباء اعتنوا في أحد التعريفين المتقدمين للعقم بذكر مدة محددة يصدق بعدها وصف العقم؛ وذلك لأن الغرض من تعريف العقم عند الأطباء هو الأن

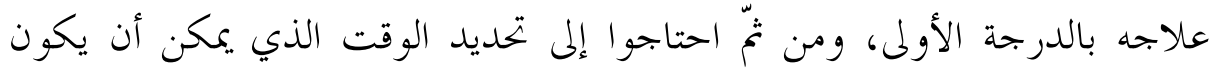

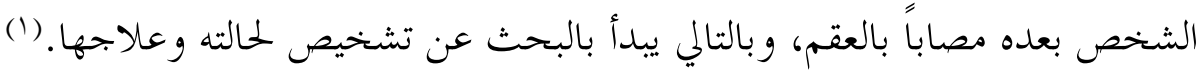

( د ) تعريف العقم عند علماء الثريعة:

تعريف العقم عند الفقهاء

وردت كلمة العقم عند الفقهاء في مواطن قليلة من كتبهم وأكثر ما وردت على

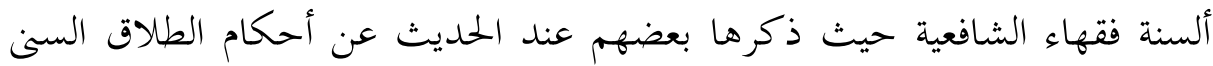

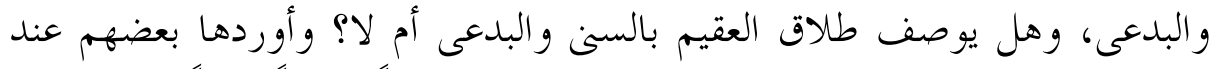

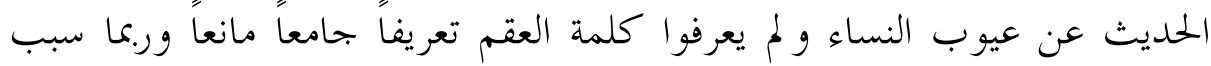

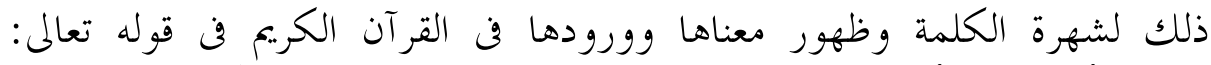

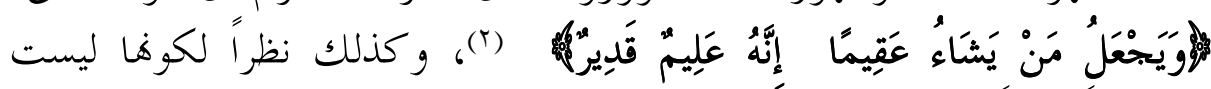

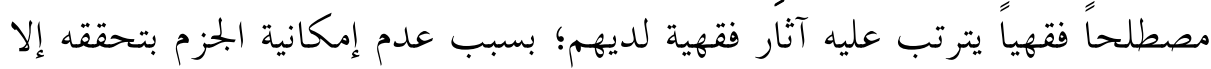
(r). بالموت

$$
\text { جاء في كتب الشافعية ما نصه: }
$$

"هل العقيم التي تكرر تزوجها للرجال ذوي التهاء النسل، و لم تحبل منهم كالآيسة؛ لأن

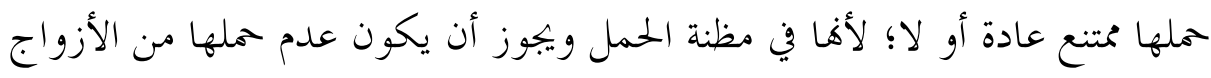

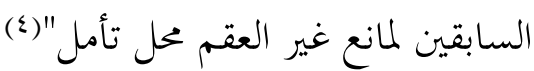
ووجاء في كتب المالكية ما نصه:

(1) العقم.. الأسباب والعلاج.. نظرة شرعية، مقال للدكتور. محمد بن هائل المدحجي، منشور على موقع الملتقى الفقهى http://fiqh.islammessage.com/NewsDetails.aspx?id=r q

(r) سورة الشورى آية ( • ( ).

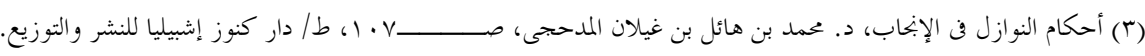

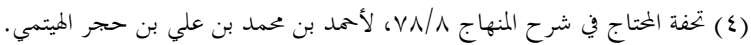
ط/ المكتبة التجارية الكبرى .مصر. 


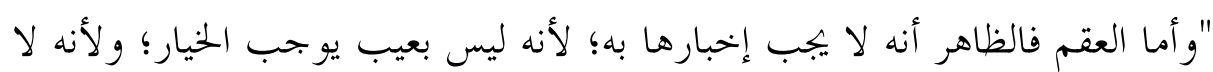

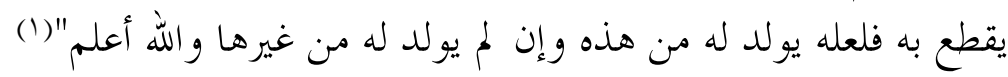

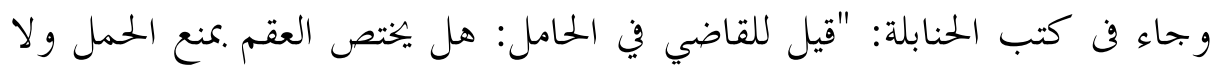

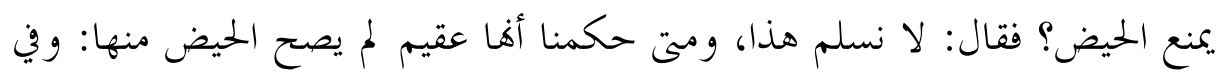

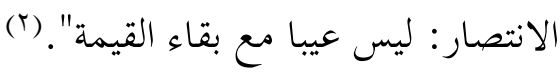

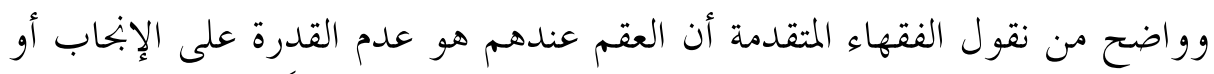

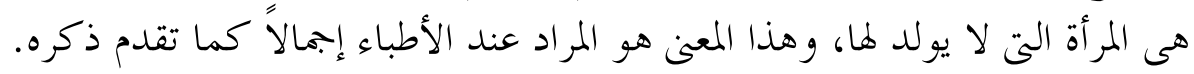

\section{تعريف العقم عند المفسرين:}

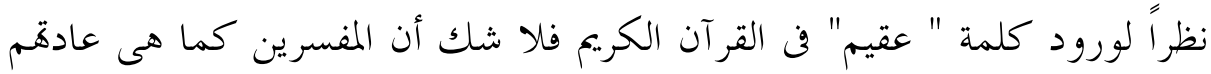

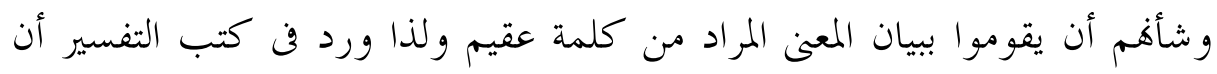

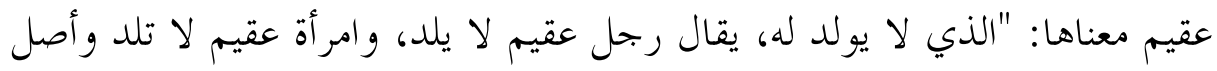

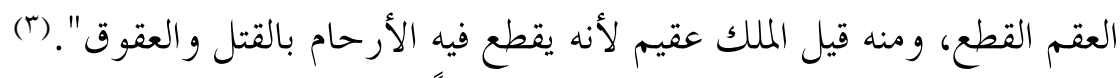

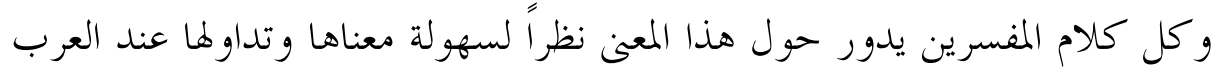
ولذا لا يو جد ما يشكل حول مفهوم كلمة عقيم الورادة في كتاب الله تعالم.

\section{تعريف العقم عند الفقهاء المعاصرين:}

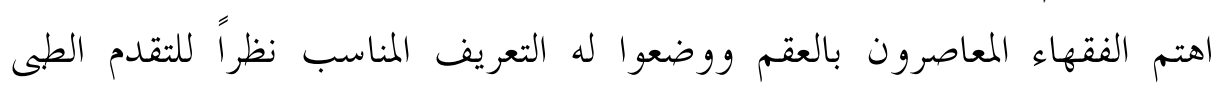

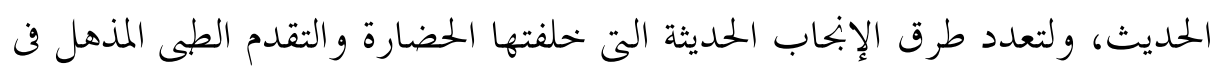

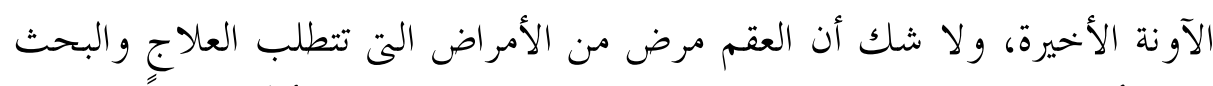

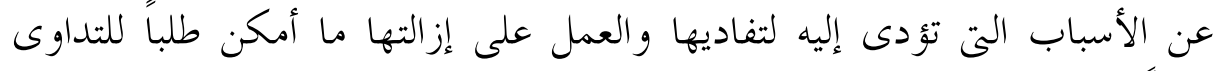

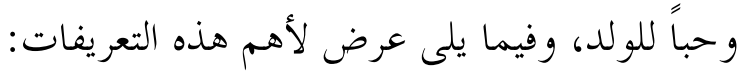

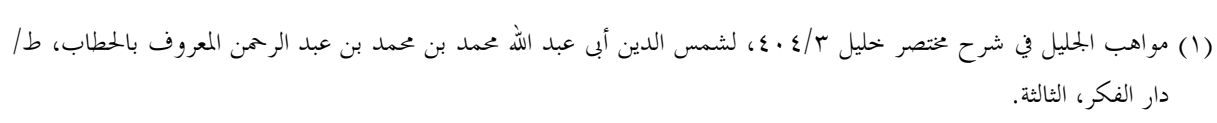

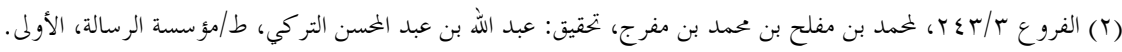

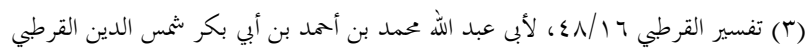

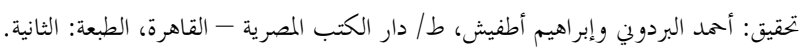




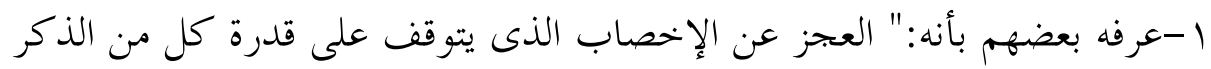

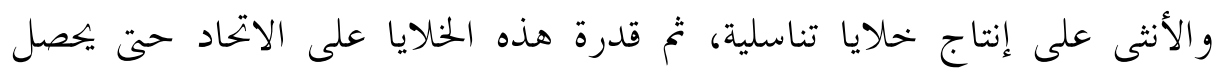

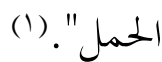

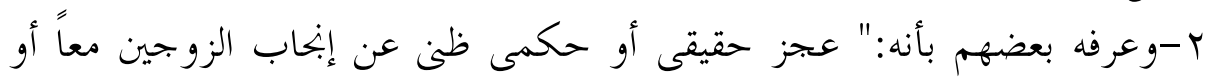

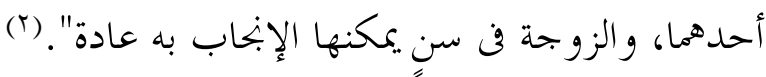

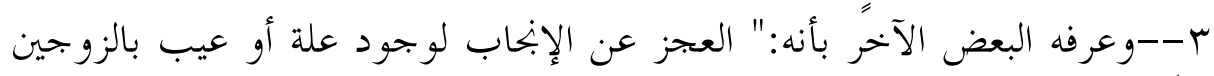

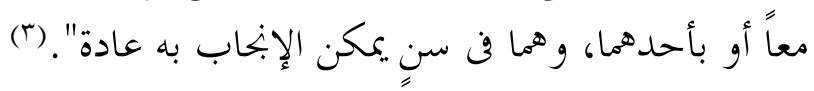

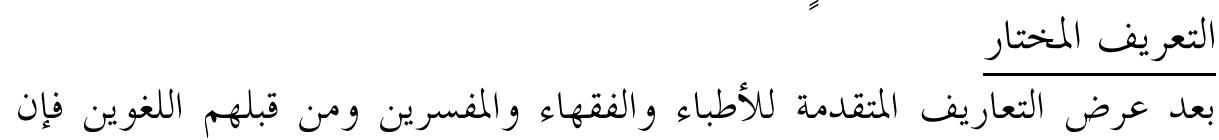

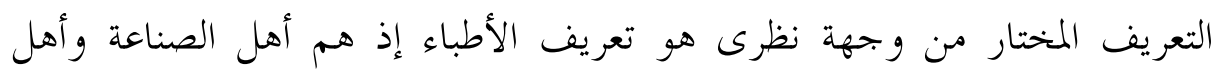

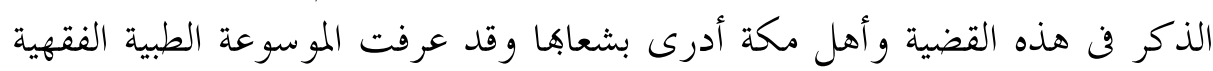

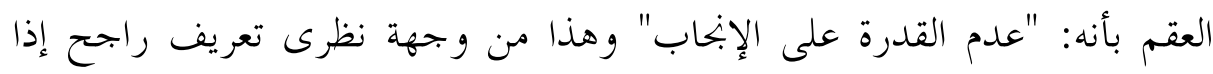

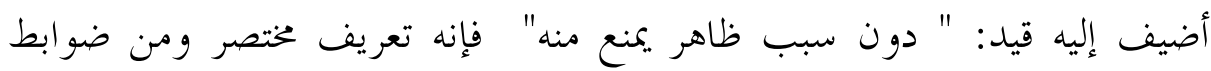

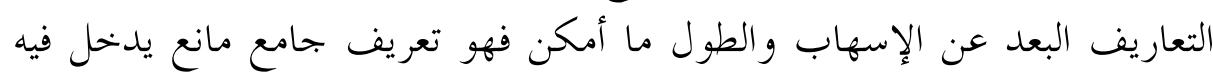

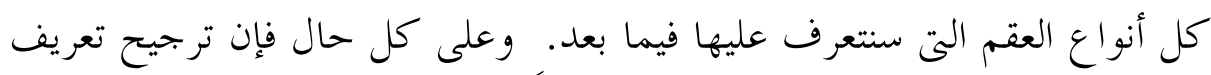

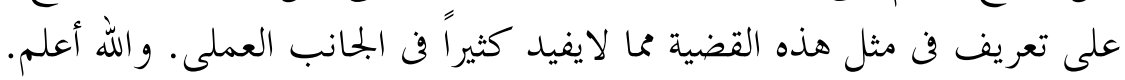

(1) هذا تعريف الدكتور محمد سلام مدكور فن كتابه: التعقيم والإجهاض من وجهة نظر الإسلام نقلاً عن الأحكام الطبية المتعلقة

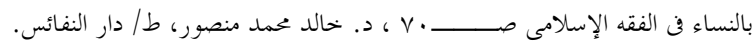

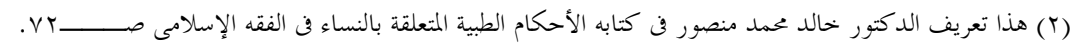

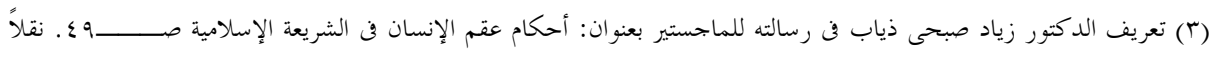

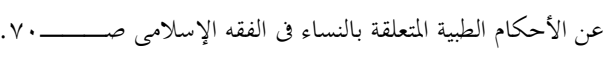




$$
\text { المطلب الثانى: أنواع العقم }
$$

يصنف الأطباء العقم إلى نوعين أساسيين هما:

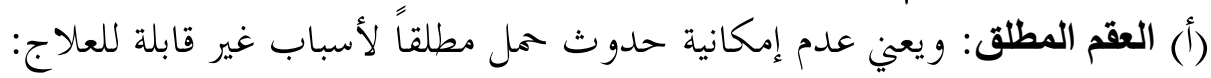

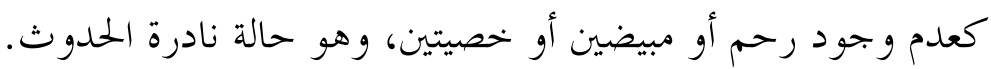

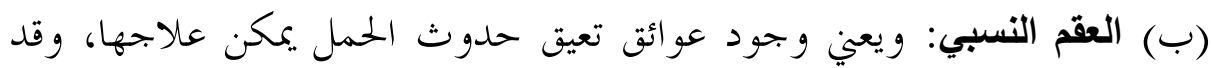

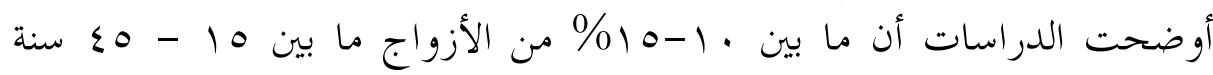
ويرغبون في الإنحاب يعانون من مشكلة العقم النببي. (1)

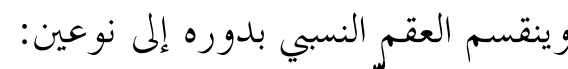

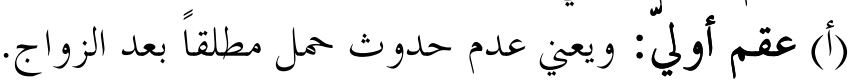

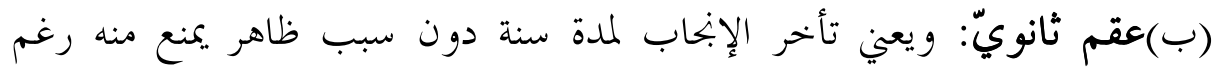

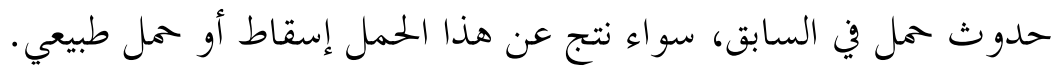

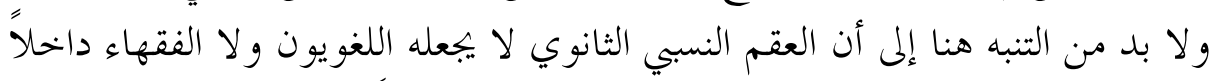

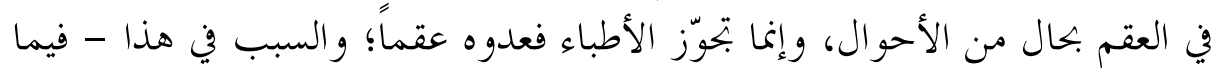
يبدو - هو عدم وجود فرق تشخيصي أو علاجي بينه وبين العقم النببي الأولي في (r). 


\section{المبمث الثانى : أسباب العقم وطرق علاجه}

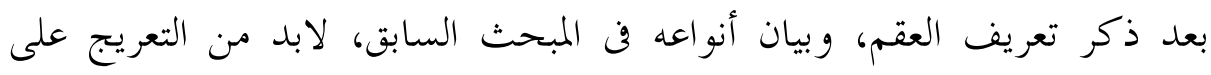

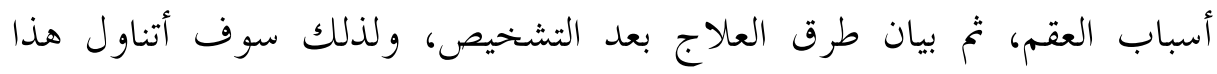

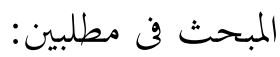

\section{المطلب الأول: أسباب العقم}

مما أن العقم مرض من الأمراض فلابد أن يكون له أسباب تؤدى إليه، و.كعرفة هذه

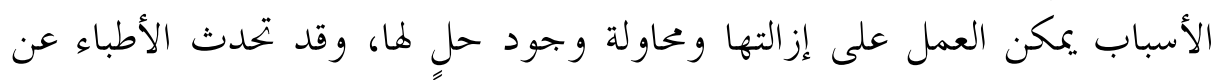

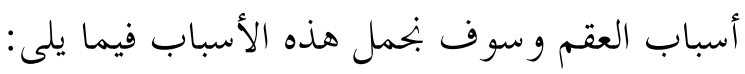

1- الأمراض الجنسية: إن الأمراضٍ الجنسية هي السبب الرئيس لحالات العقم

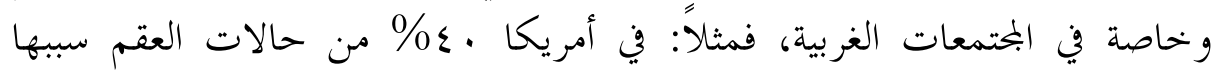
الالتهابات الناتجة عن الأمراض الجنسية؛ إذ تؤدي هذه الالتهابات إلى تليف فئل الأنسجة

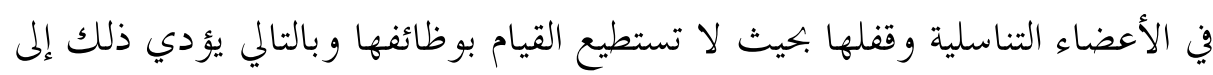

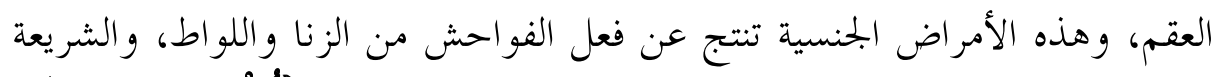

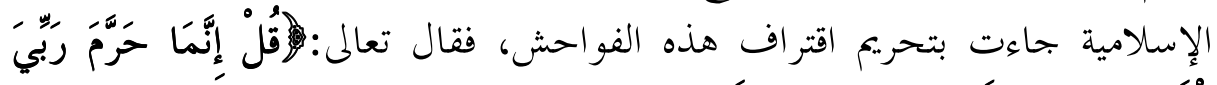

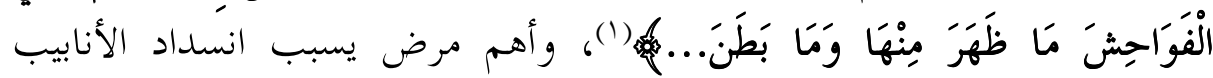

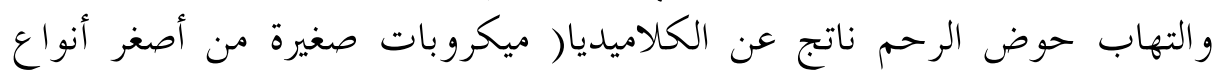

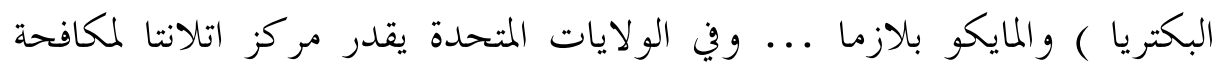

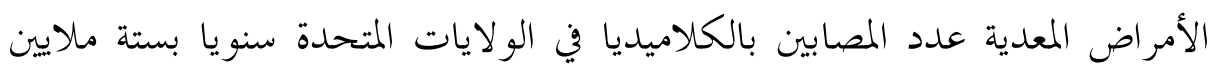

(r) شخص. (1)

(1) سورة الأعراف آية ( (Tr).

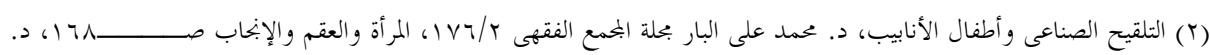
إبر اهيم الأدغم. 
r- الإجهاض: فبسبب الإباحية في البحتمعات غير الإسلامية انتشر الإجهاض فيها

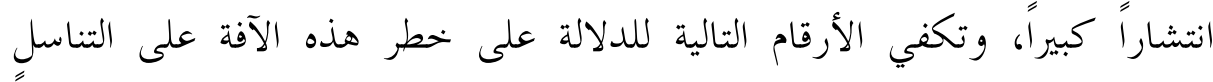

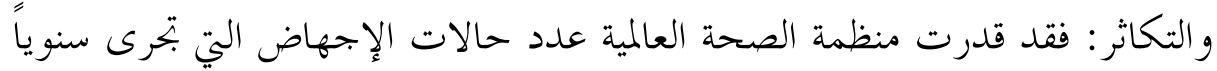

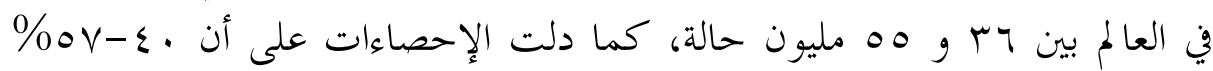

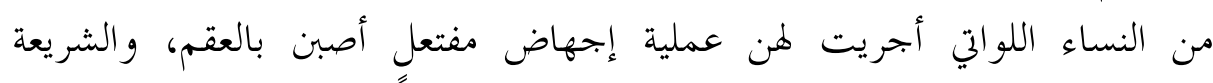

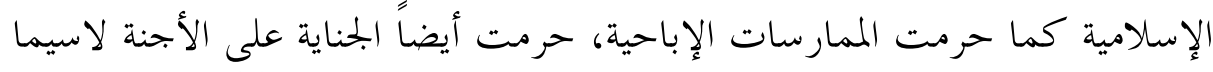

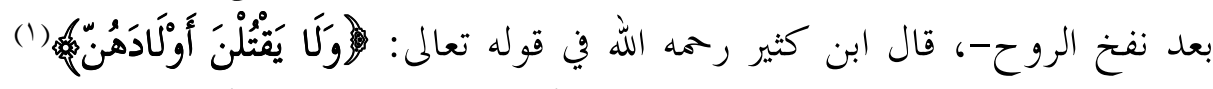

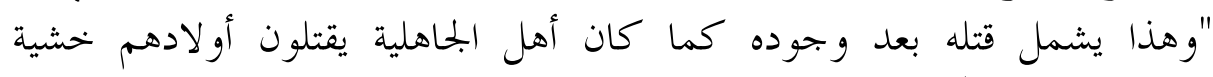

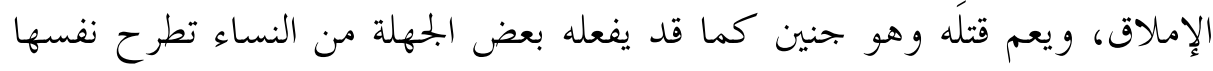

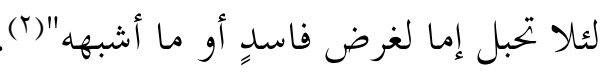

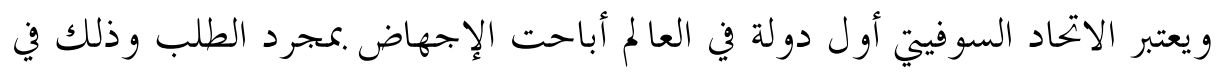

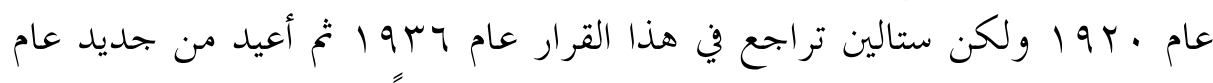
1900، وتبلغ حالات الإجهاض ثلاثة ملايين حالة سنوياً في الاتحاد السوفيتي العان وفي اليابان ثلاثة ملايين حالة إجهاض سنو ياً (r).

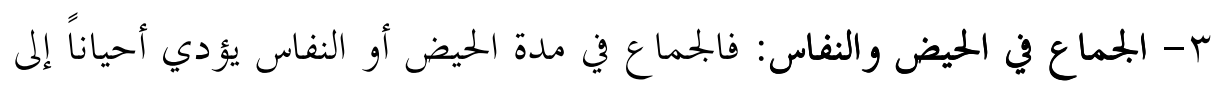

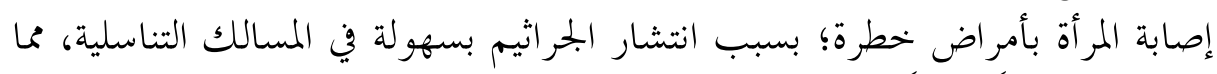

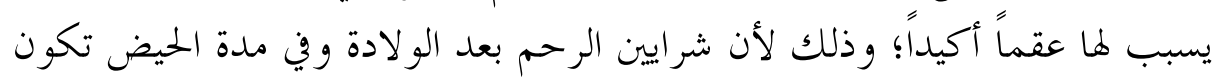

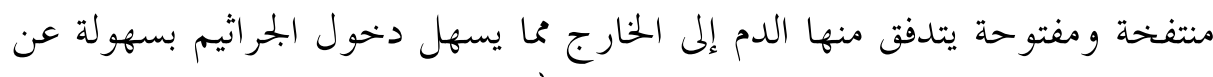

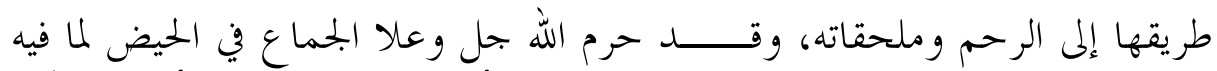

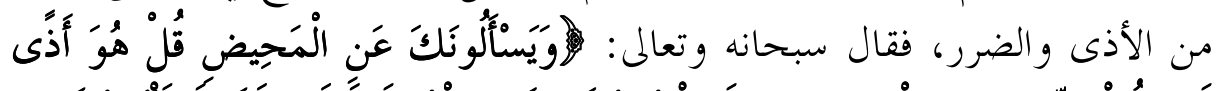

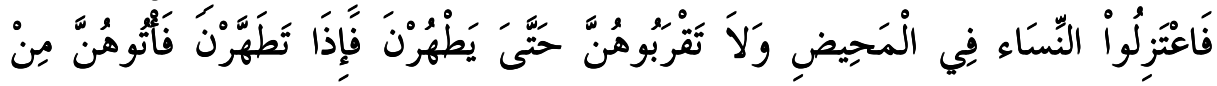

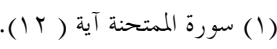

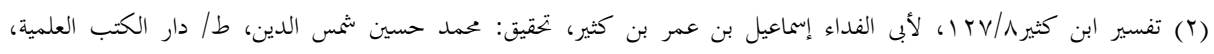

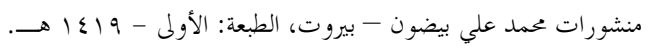

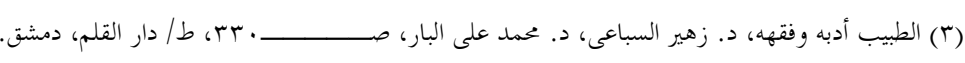




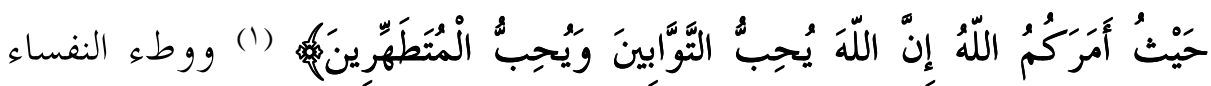

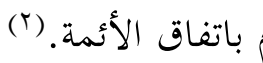

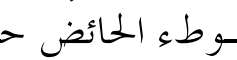

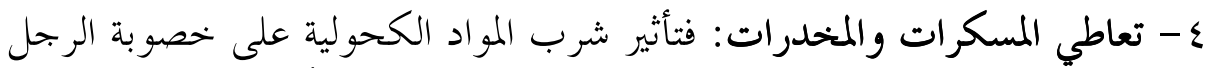

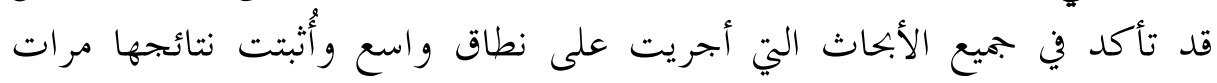

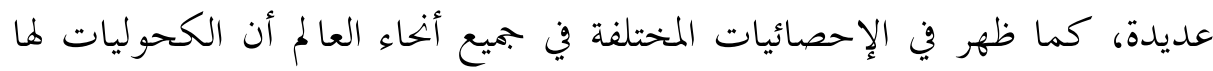

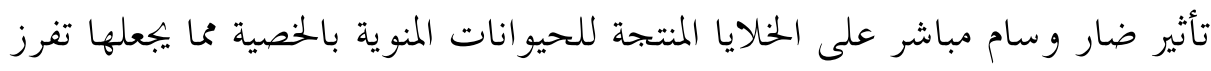

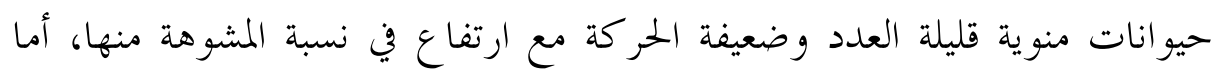

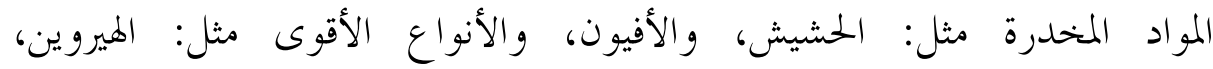

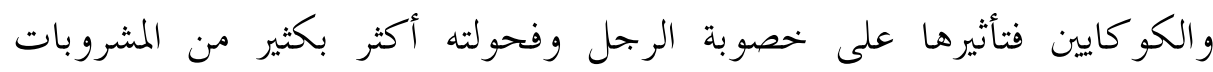

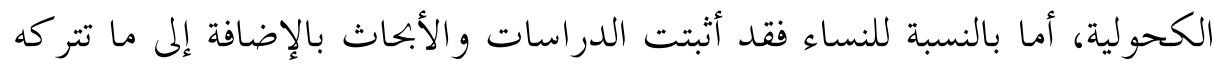

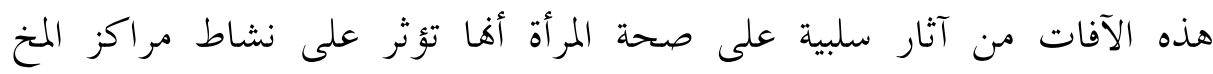

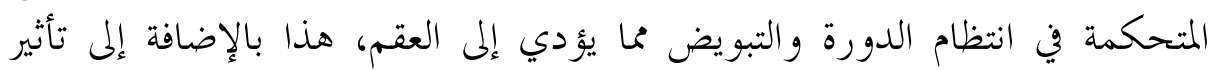

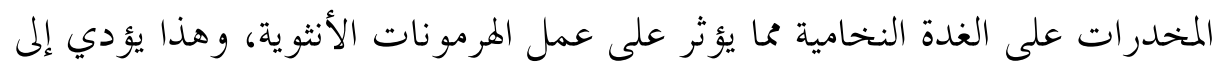

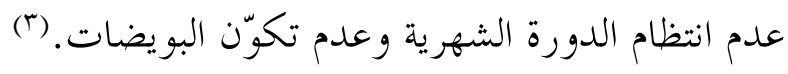

وهذه المسكرات والمخدرات من الأمور الخرمة في الشريعة الغراء، فالعقل له منزلة

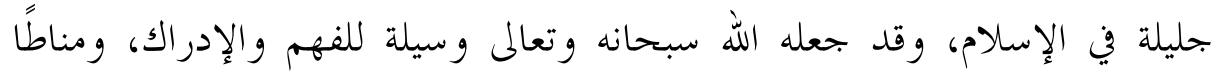

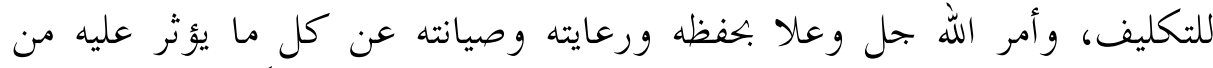

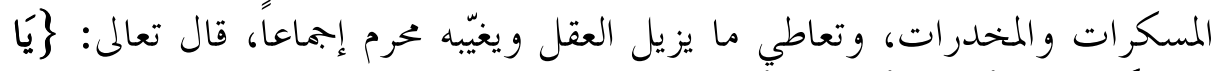

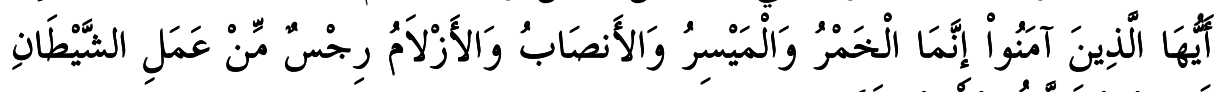

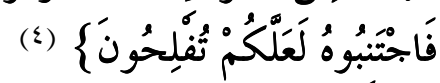

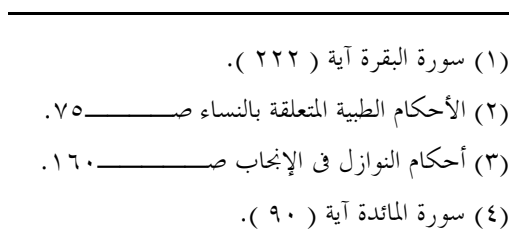


فالتدخين له آثار ضارة على الجهاز التناسلي ويمكن أن يؤدي إلى العقم، ومن هذه

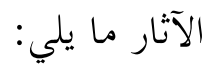

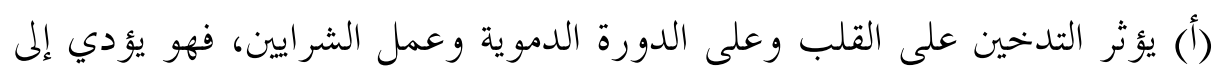

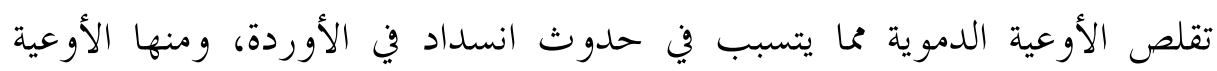

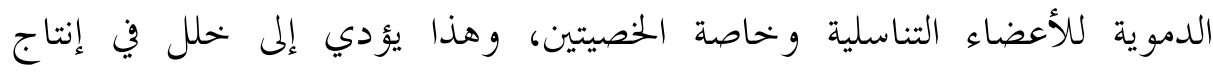

$$
\text { الحيوانات المنوية. }
$$

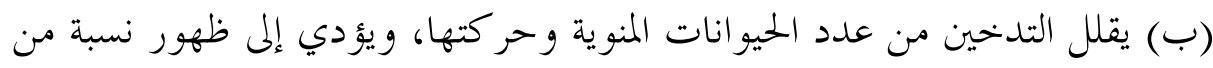

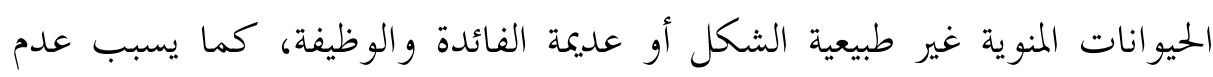
قدرة هذه الحيوانات المنوية على تلقيح البويضة.

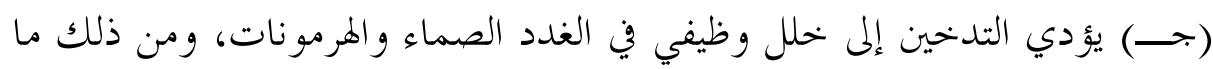

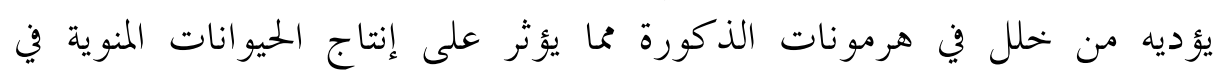

(1) الخصيتين.

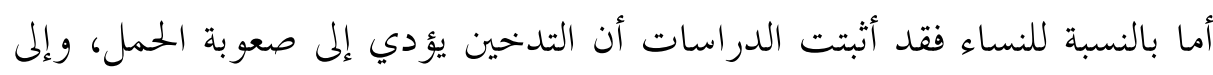

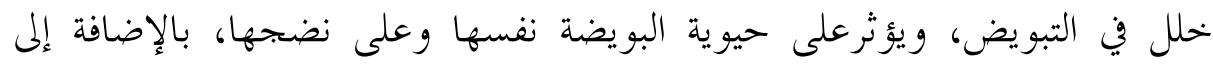

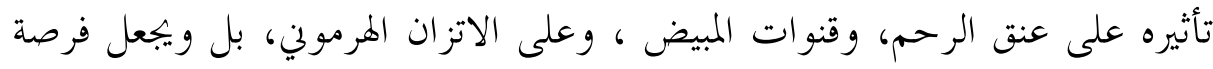

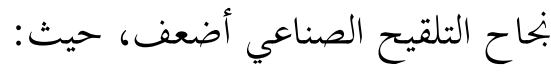

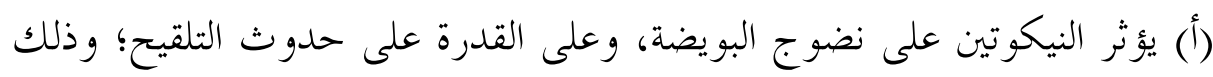

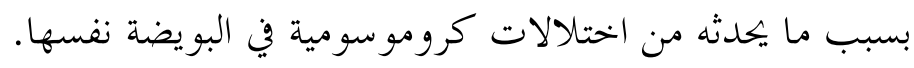

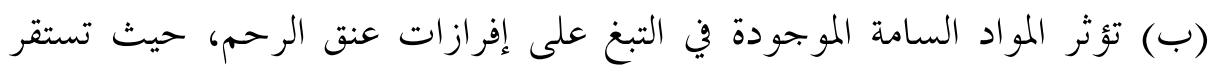

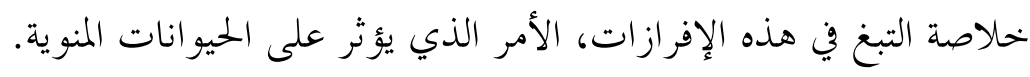




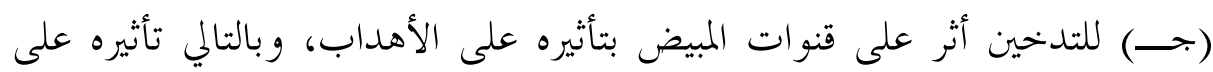

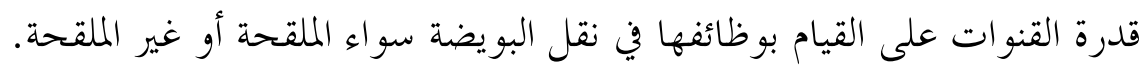
(د) وجدت علاقة بين التهابات الحوض المزمنة والثدخين، فاحتمالية إصابة المدخنات

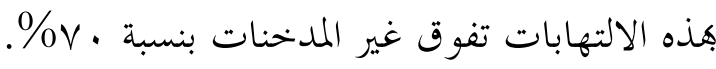

(هـ)هناك أبحاث كثيرة أنبتت تأثر نسب بناح عمليات أطفال الأنابيب بتدخين

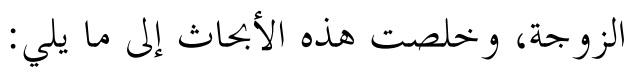

1-فرص نجاح عملية أطفال الأنابيب للمدخنات هي نصف النسبة لدى غير

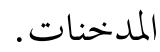

ץ-المو اد السامة التي يحتو يها التبغ وخلاصته تؤثر على هرمون (الإستروجين) بالتأثير

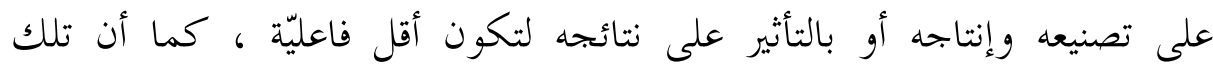

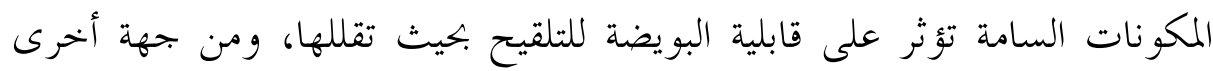

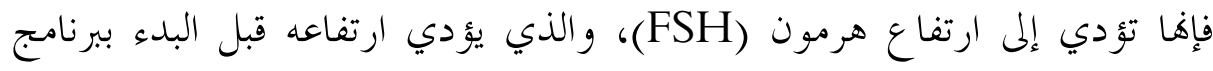
التنشيط لعملية أطفال الأنابيب إلى فرمل إنساع العملية.

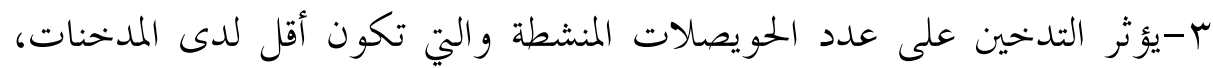

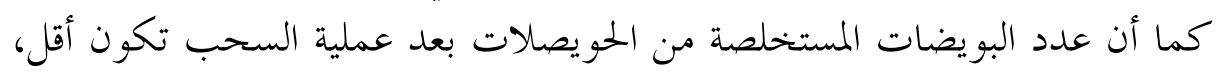
وإمكانية تلقيحها تكون أضعف.

وضرر التدخين على أجهزة الجسم المختلفة أصبح معروفاً للجميع، وخاصة جهاز

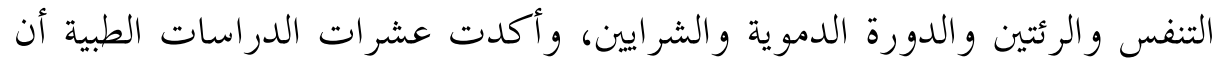

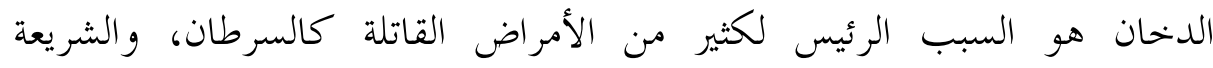

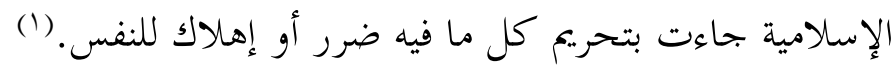

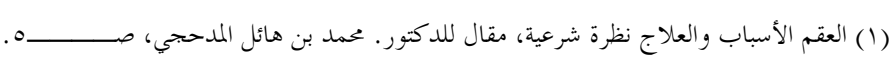


ه-استعمال اللولب لمنع الحمل: يعتبر إدخال اللولب السبب الثاني لالتهاب الأنابيب

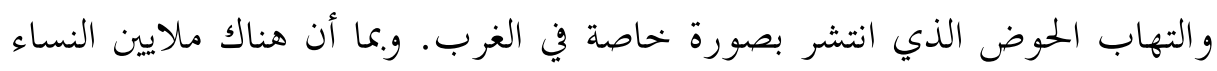

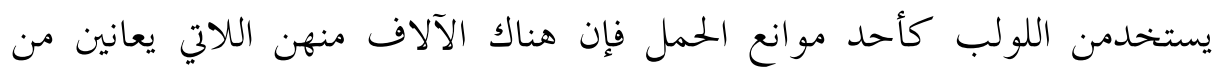

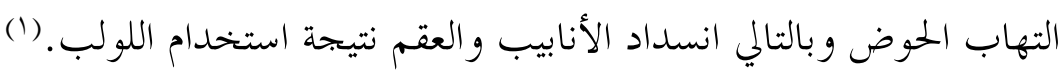
צ-تأخير سن الزواج: يعتبر تأخير سن الزواج إلى ما بعد سن الخامسة والعشرين

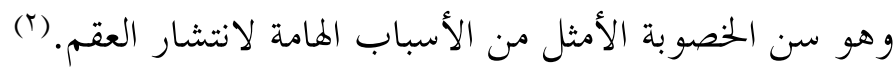

V-أمراض أخرى: تعتبر نادرة في الغرب ولكنها غير نادرة في البلاد النامية مثل

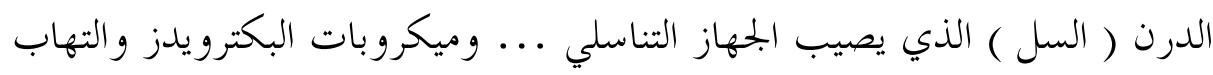

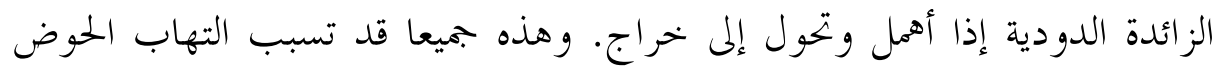

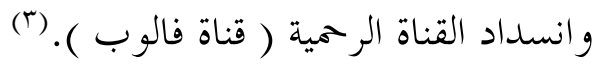

م-ضيق المهبل: يعتبر ضيق المهبل من اهم الأسباب المؤدية للعقم عند المرأة، لأنه

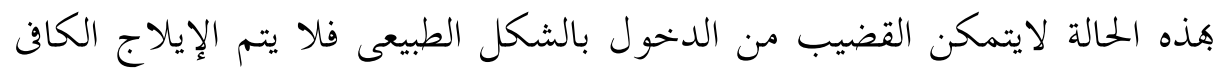

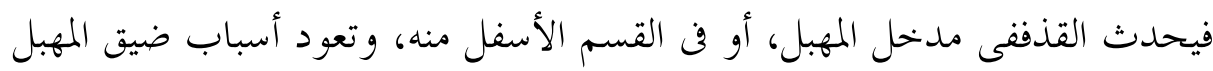

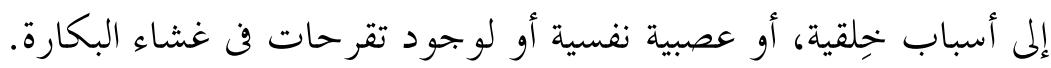

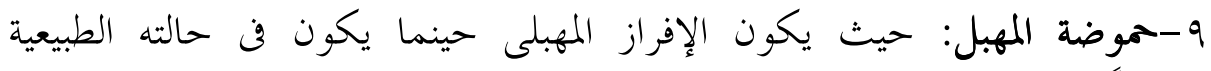

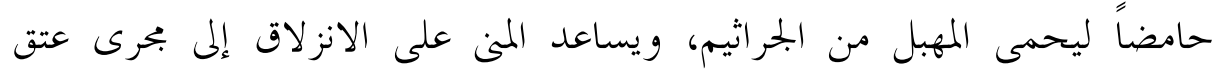

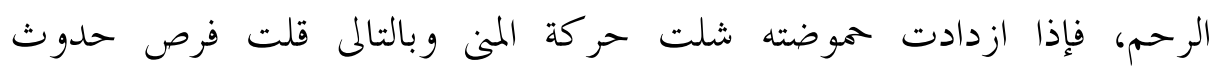

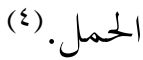

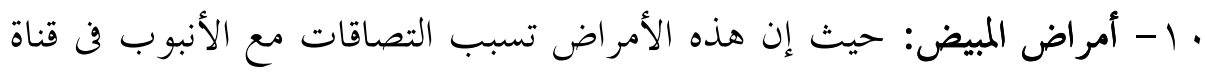

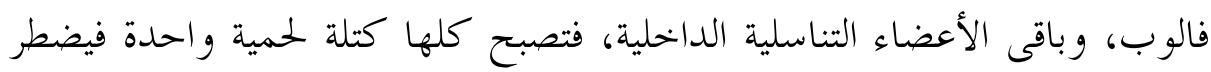

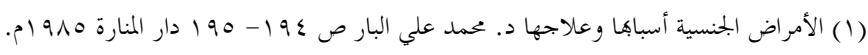

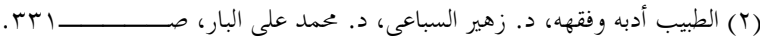

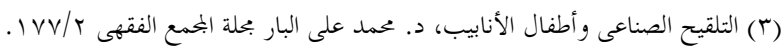

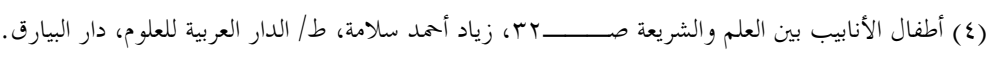


الجراح عند اسئصال ورم المبيض استئصال المبيض كلياً أو جزئياً مما يتسبب فن عقم

المرأة.

1 1 - عدم القدرة على إنتاج بويضة قابلة للتلقيح: وهو من أهم حدوث العد العقم وهو

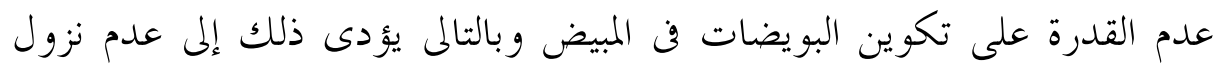

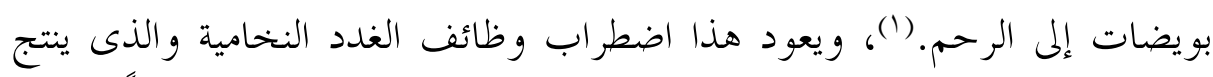

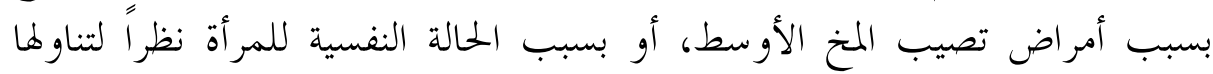

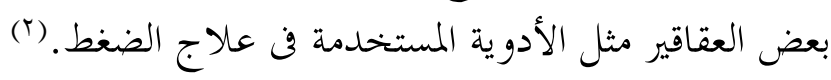

r العت العوامل النفسية: وهي قد تكون مسببة للعقم، وبعض العو امل النفسية المسببة

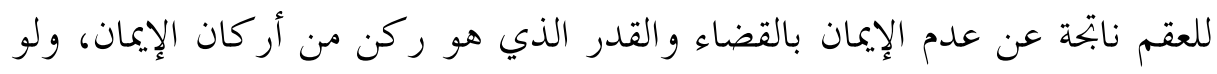

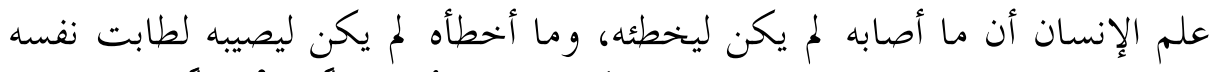

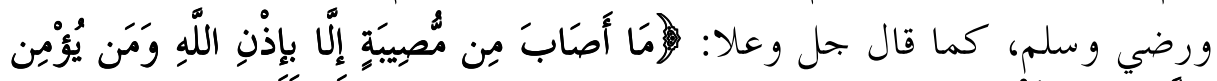

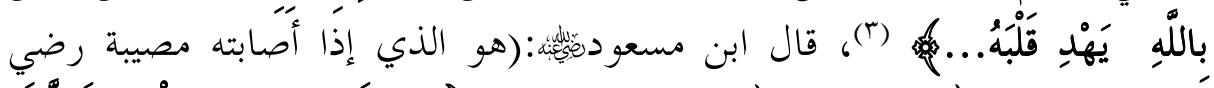

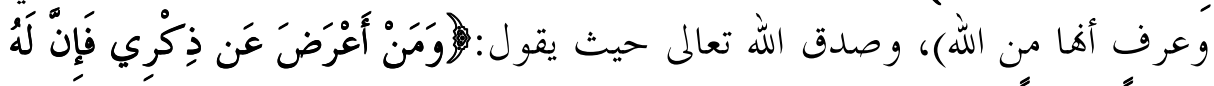

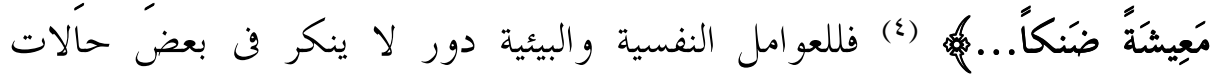

العقم. (o)

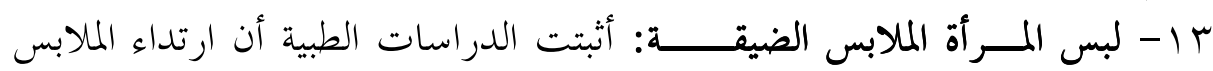

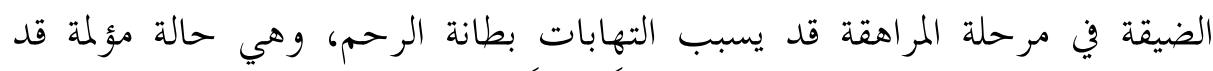

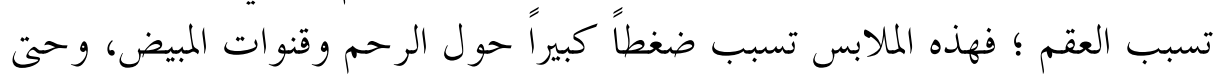

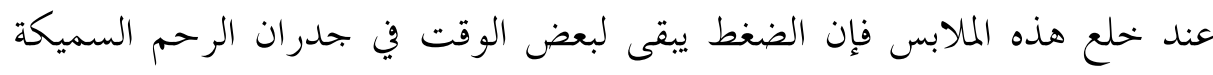

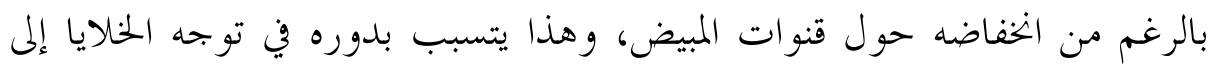

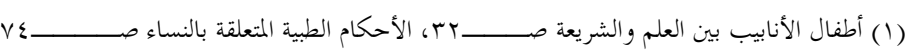

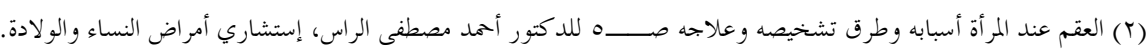

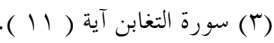

(ع) سورة طه آية ( ع ا I ) .

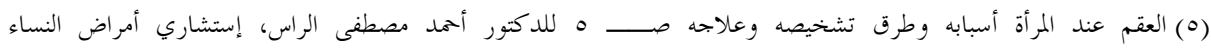

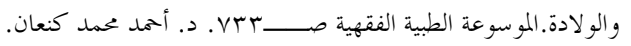




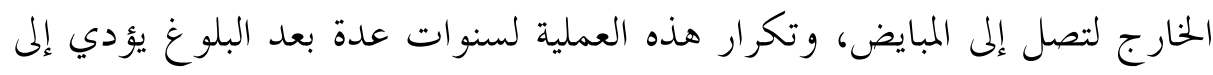

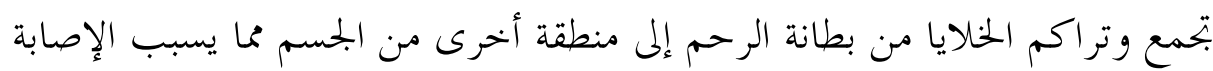

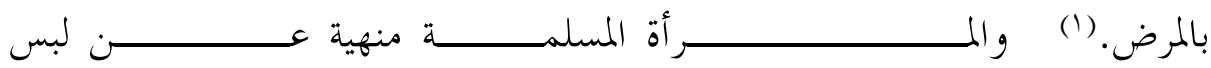

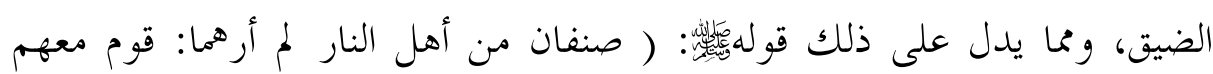

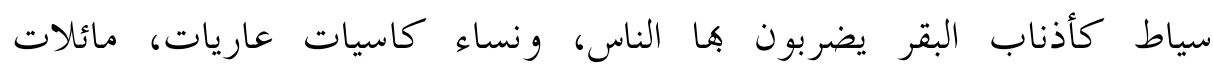

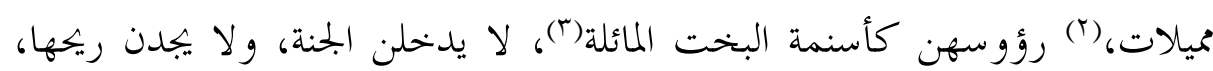

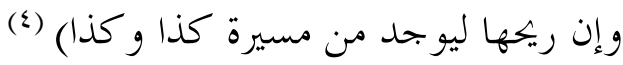

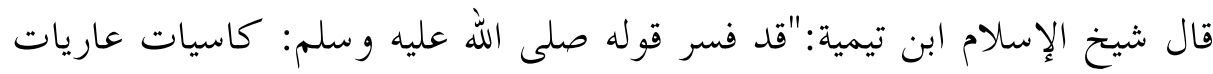

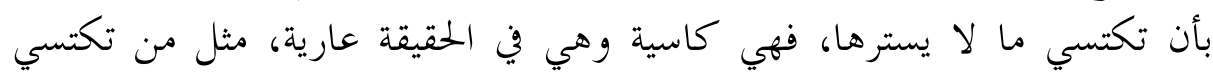

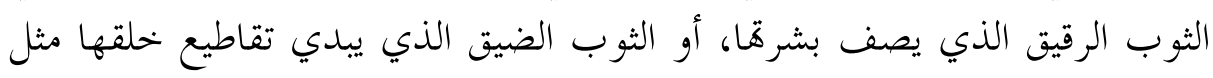

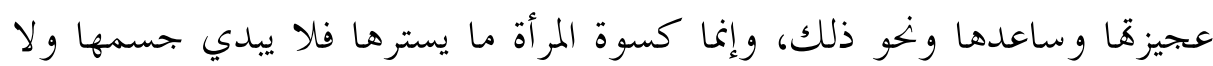

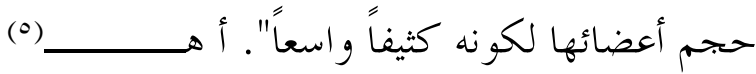

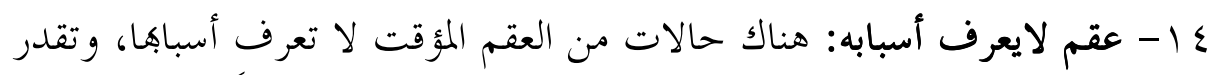

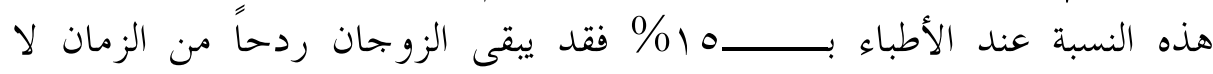

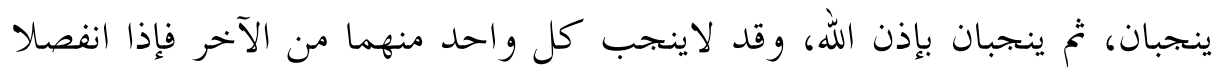

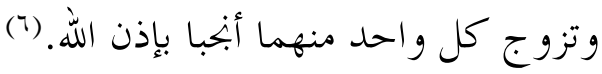

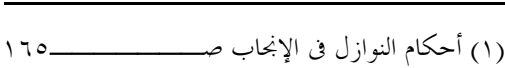

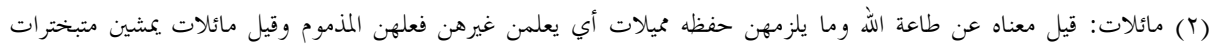

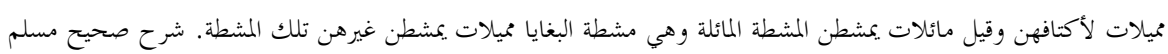

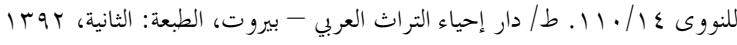

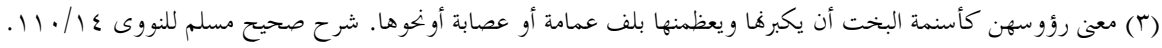

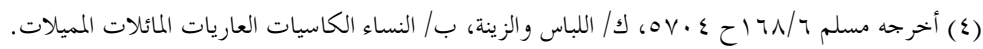

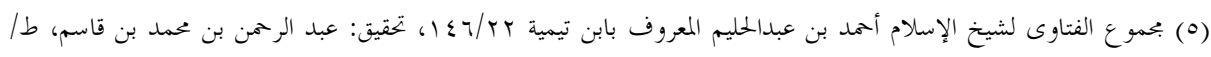

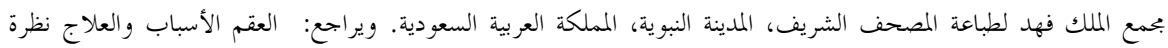

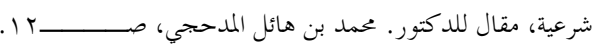

$$
\begin{aligned}
& \text { (T) الموسوعة الطبية الفقهية صــــ VTr. د. د. أحمد محمد كنعان. }
\end{aligned}
$$




\section{المطلب الثانى: طرق علاج العقم}

لم يهتم الأطباء بمعالجة الأسباب وإنما اهتموا .معالجة النتيجة فكان عاقبة أمرهم

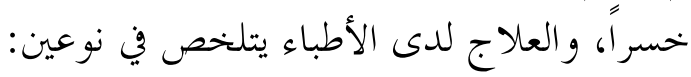

\section{النوع الأول : طرق عامة لعلاج العقم ومنها}

$$
\text { 1 - إسرعة معالجة الأمر اض الجنسية. }
$$

بإبراء الإجهاض في بيئة معقمة أي في المستشفيات وهذا يستدعى السماح به قانوناً.

ب-إجراء عملية فتح الأنابيب المغلقة وهذه عملية عسيرة ودقيقة ولا يبريها إلا أفراد

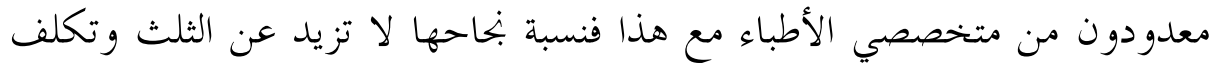

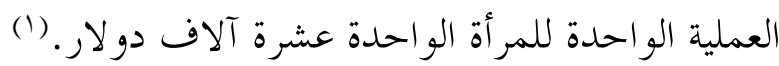

إن علاج مشكلة العقم يتلخص في علاج أسبابه الحقيقية وهي:

$$
\text { 1-الزنا وانتشار الإباحية الجنسية. }
$$

r-الإجهاض: وعلاج الإجهاض يكون .منعه وتوضيح حرمته وخحاصة في محيط

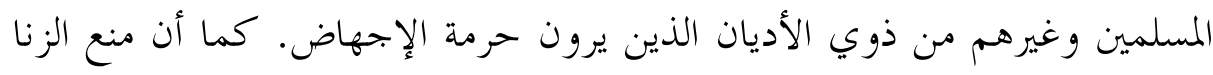

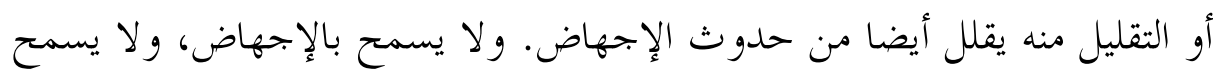

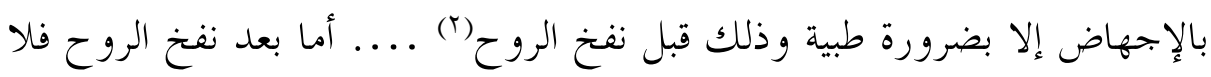

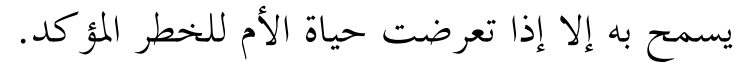

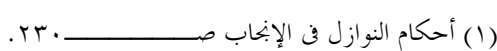

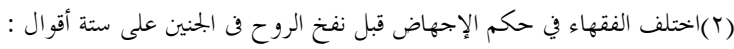

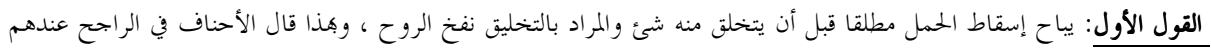
وبعض الشافعية والشيعة الزيدية.

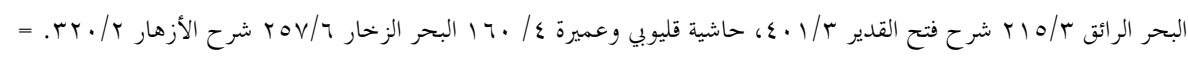


ب-استخدام اللولب كو سيلة من وسائل منع الحمل، حيث ينبغي أن لا يشجع على

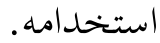

ع-منع الجماع أثناء المحيض بحيث يوضح للمسلمين خاصة ولغيرهم بصورة عامة

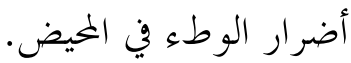

ه-علاج الأمراض المستوطنة والمعدية مثل الدرن وتوفير المستشفيات والأطباء

لتشخيص وعلاج الالتهابات مثل الزائدة الدودية و وحلافها.

=القول الثاني: يحرم إسقاط الجنين قبل نفخ الروح فيه في أى طور من أطوار النطفة أو العلقة أو المضغة، وهذا قال المالكية في المعتمد

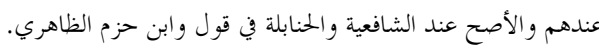

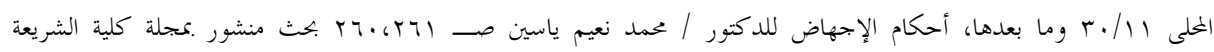

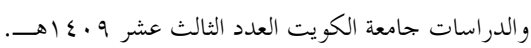

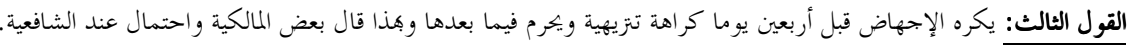

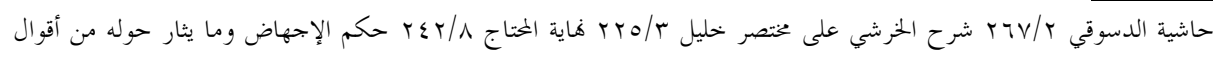

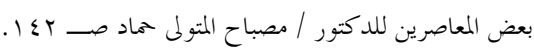

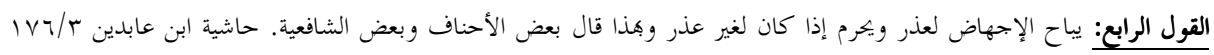

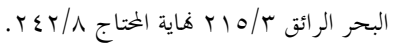

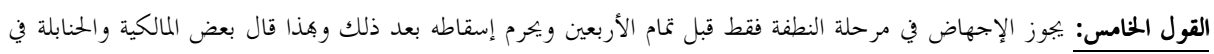

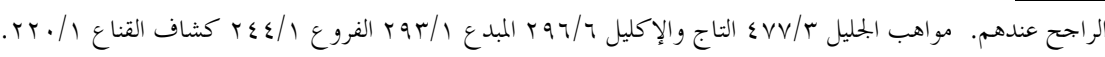

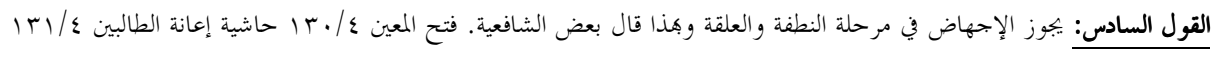

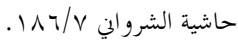

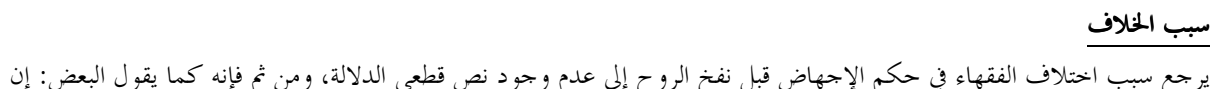

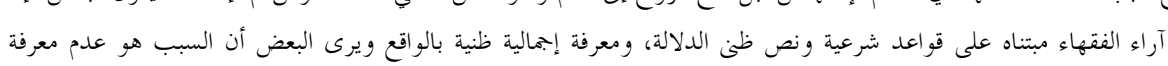

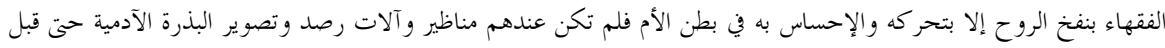

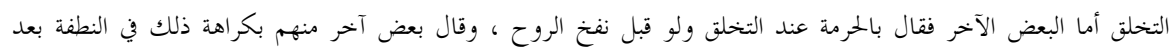

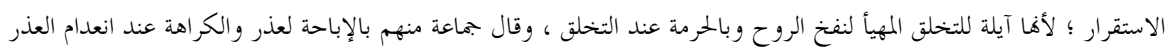

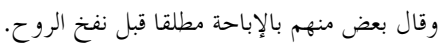
يراجع فن الأقوال وذكر سبب الخلاف بحث أخينا الدكتور محمد إبراهيم سعد، الإجهاض بين الحظر والإباحة، دراسة مقارنة 


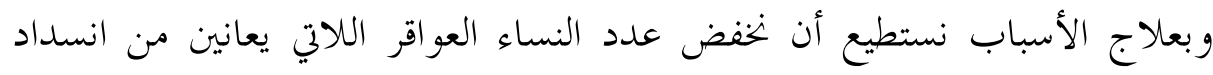

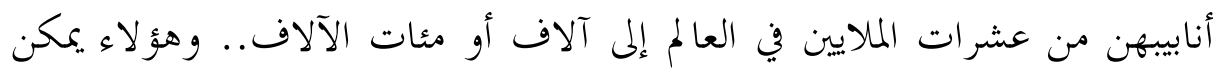
علاجهن بطريقة من الطرق بشرط أن تخفض تكاليف هذه العمليات الباهظة. فإزالة العقم من الوجود غير ممكنة عمليا ومنافية للقوانين الطبيعية، وخير أن يبقى إنى إنياء

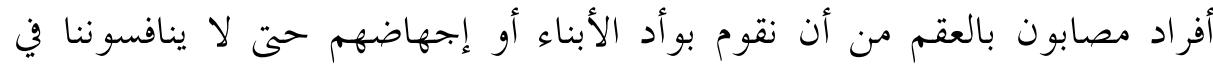

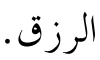

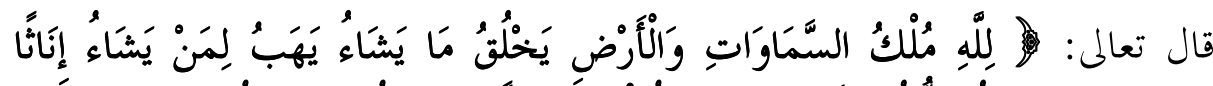

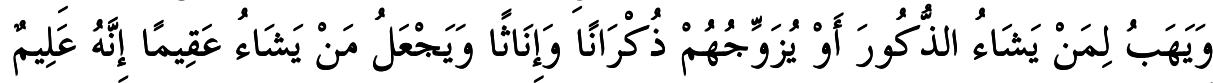

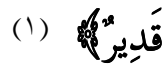

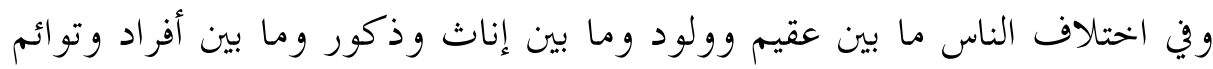
تتجلى قدرة الخالق العظيم، وعلمه الخيط بكل صغئ صغيرة ولئ وكبيرة فيجعل الحياة متو ازنة.

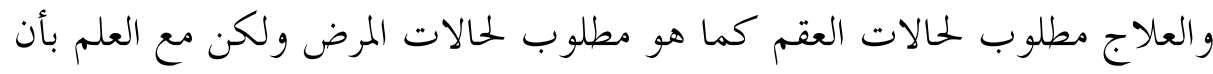

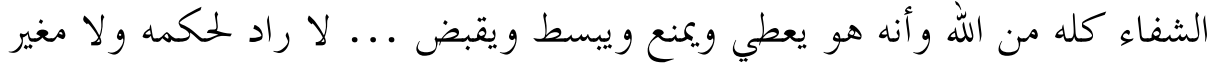

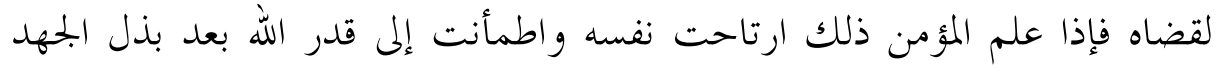

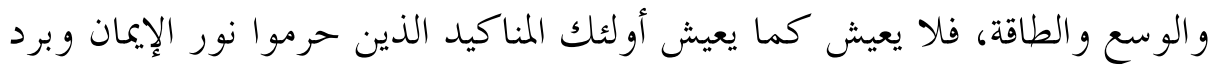

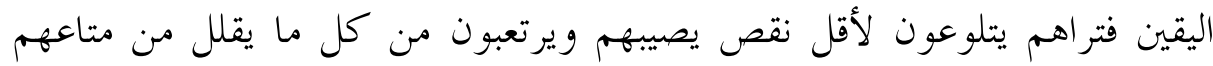

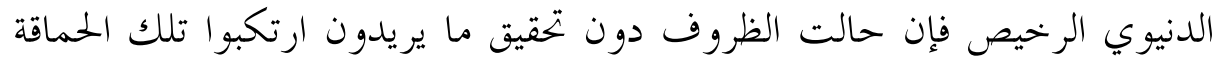

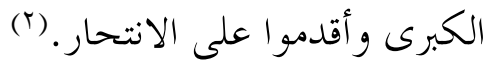

(1) سورة الشورى آية (9 (1) : .0. ).

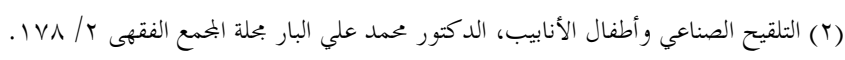




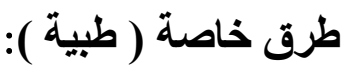

الطرق المتقدم ذكرها لعلاج العقم طرق عامة وتبقى بعد ذلك الطرق الخاصة

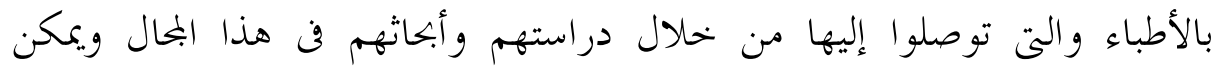
تلخيصها فيما يلى: أولاً: العلاج بالعقاقير و الأدوية

يمكن علاج كثير من أسباب العقم عند المرأة بواسطة العقاقير والأدوية، فعلاج العقم

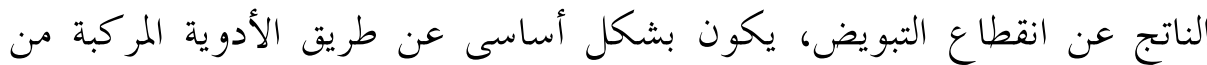

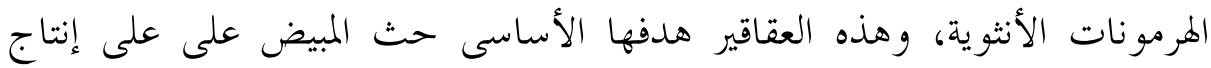

بييضات صالحة للتلقيح. (1) ثانياً: التلقيح الصناعى الداخلى وهو عبارة عن(r) إدخال السائل المنوى في البحارى التناسلية عند المرأة همدف الإبجاب

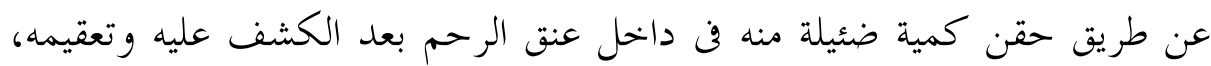

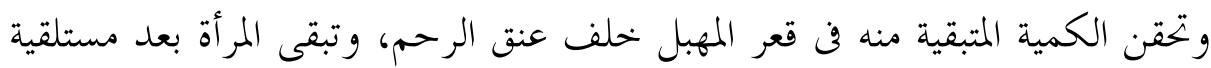

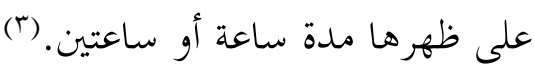
ويستخدم التلقيح الصناعى الداخلى في الحالات التالية: (ع)

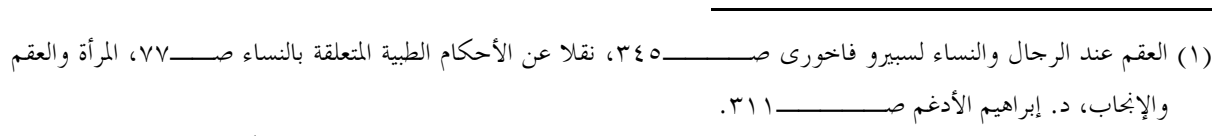

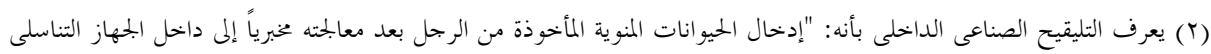

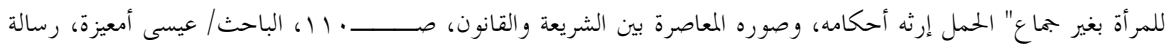
مقدمة لنيل درجة الماجستير بكلية الشريعة كلية العلوم الإسلامية بالجزائر.

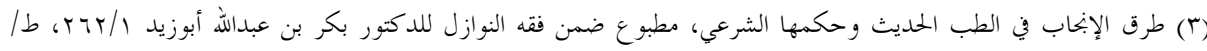
مؤسسة الرسالة، الطبعة: الأولى. (ع) التلقيح الصناعى له ضوابطه الشرعية التى يجب الإخذ بها والإلتز ام معاييرها عند من قال بجو ازه من الفقهاء المعاصرين، أجمل هذه الضو ابط فيما يلى: 


$$
\begin{aligned}
& \text { 1-إذا كانت حموضة المهبل تقتل الحيوانات المنوية بصورة غير اعتيادية. } \\
& \text { ب-إذا كانت إفرازات عنق الرحم تعيق ولوج الحيوانات المنوية.(1) } \\
& \text { ثالثاً: العلاج بالتلقيح الصناعى الخارجى ( طفل الأببوب )(r) }
\end{aligned}
$$

تعتمد فكرة التلقيح الخارجى على أخذ البييضة من المرأة عند وقت التبويض بواسطة

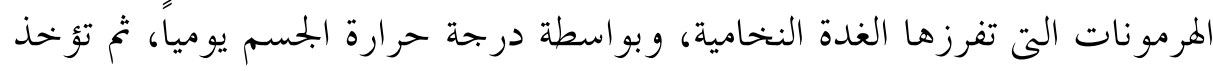

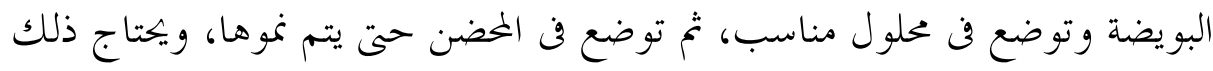

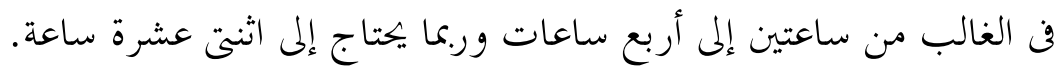

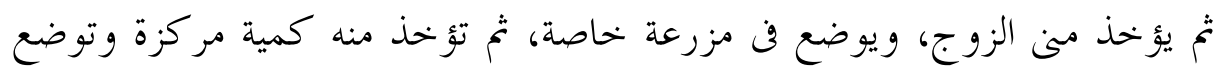

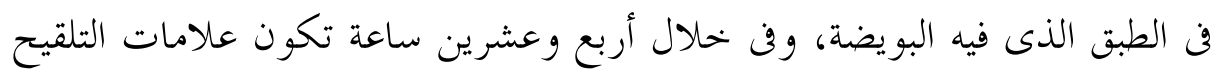

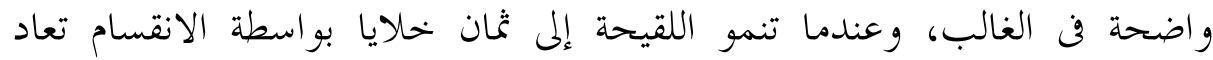
اللقيحة إلى الرحم وإذا شاء الله تعلق بالرحم و وتتحول إلى تلى جنين.

ويستخدم التلقيح الصناعى الخارجى في علاج الحالات التالية:

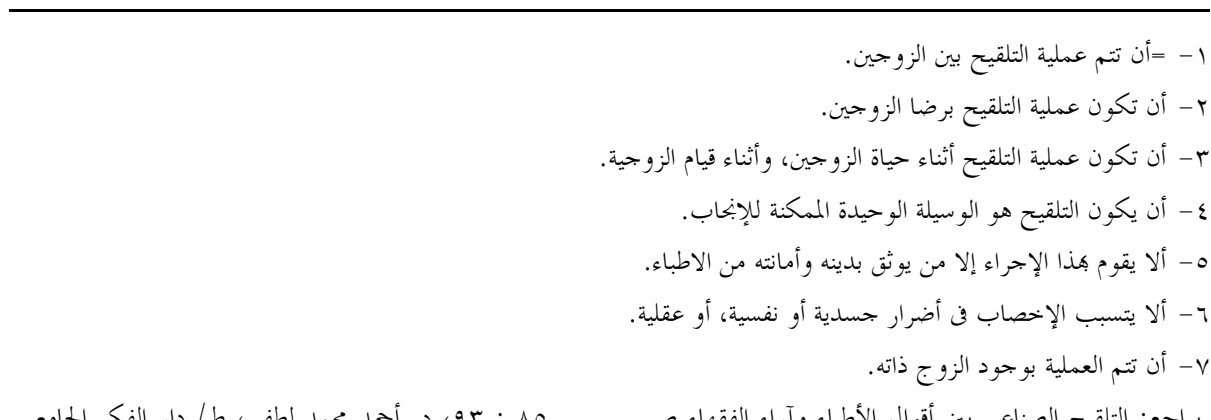

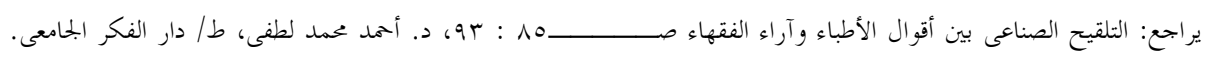

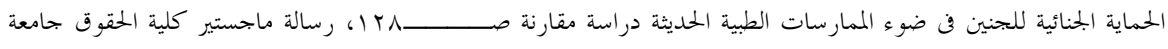

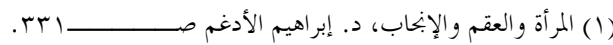

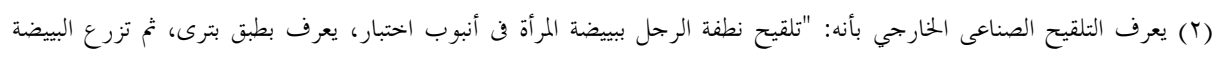

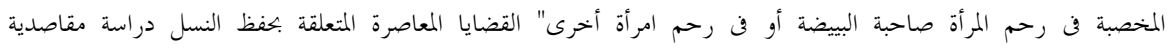

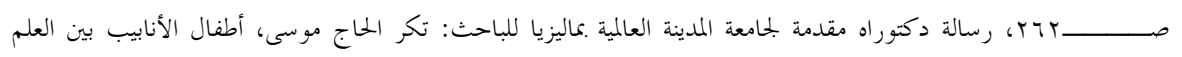

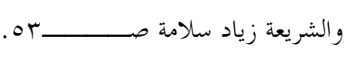


ا-الأمراض الخاصة بالأنابيب ( قناتى فالوب ) بسبب قفلها أو اسئصاها جراحياً،

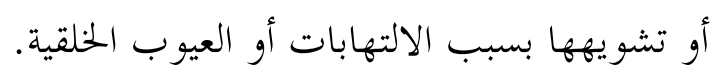

r-إفرازات عنق الرحم المعادية للحيوانات المنوية.

(1) ب-حالات العقم غير معروفة النسب.

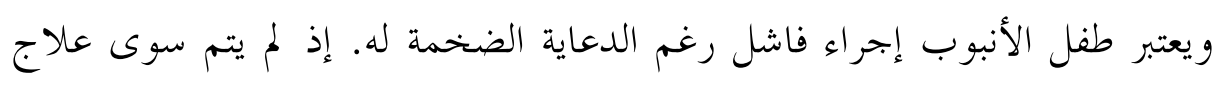

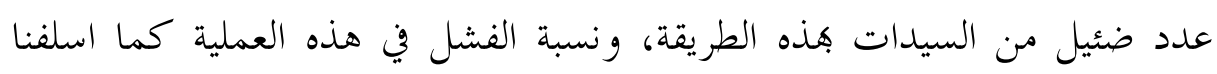

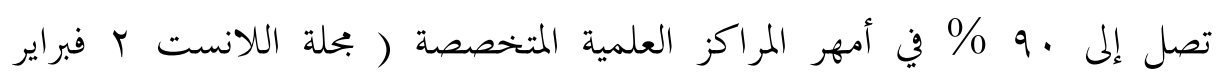

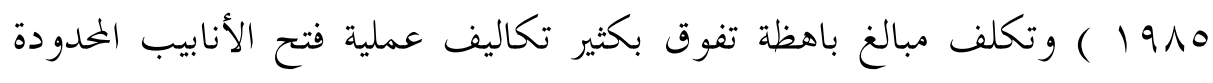
النجاح

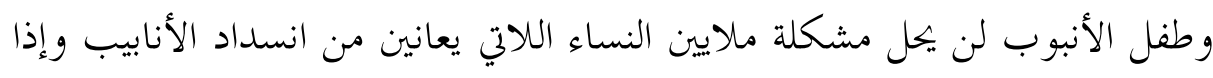

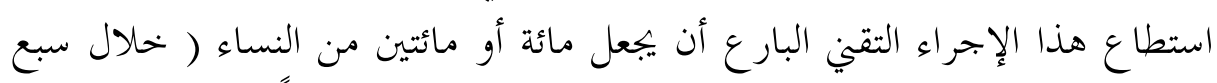

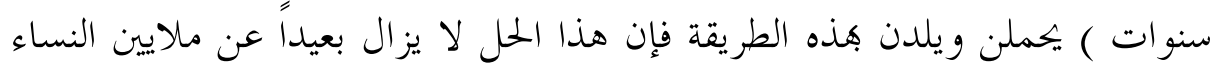
العاقرات.

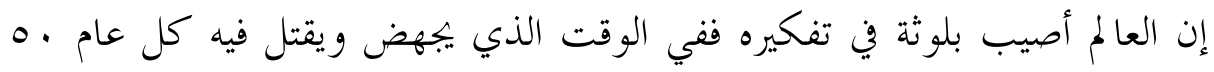

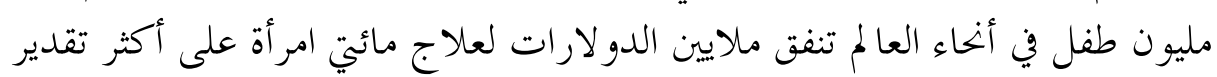
في العالم بواسطة طفل الأنابيب.

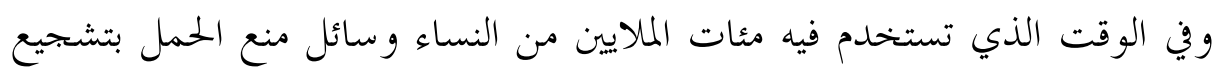

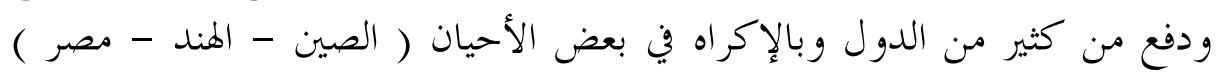

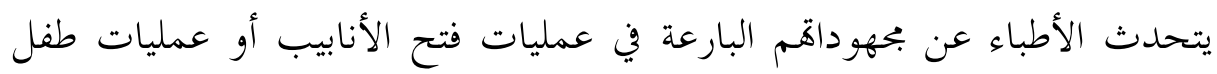

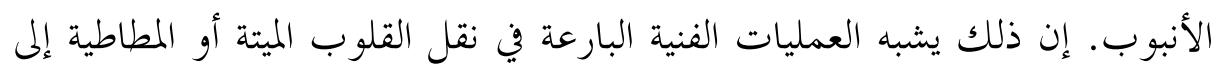

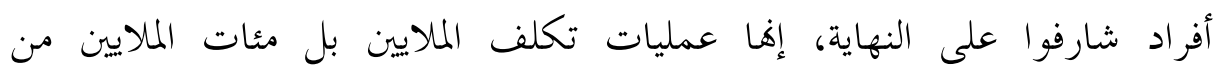

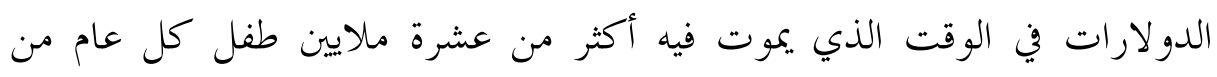


الجوع والإسهال!! إن إنفاق هذه المبالغ في إنقاذ هؤلاء الأطفال سيجعل من الممكن إلمان

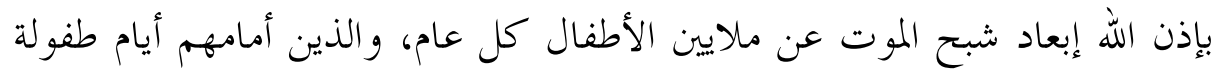

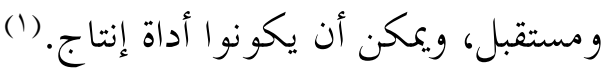

$$
\text { رابعاً: العلاج بالجر احة وتمبن }
$$

إذا فشلت معالجة العقم بالأدوية والعقاقير الطبية، فإنه يلجأ إلى الجراحة التي يتم فيها

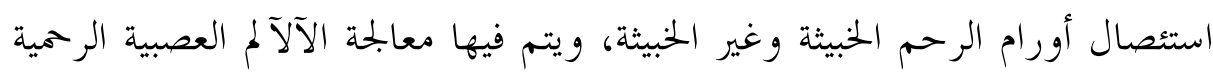

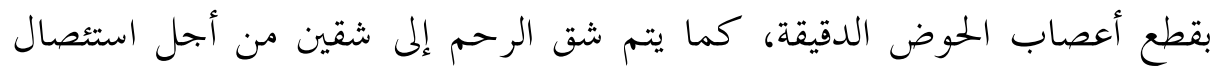

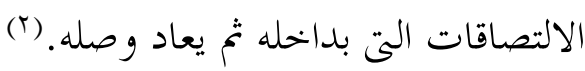




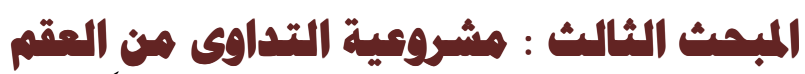

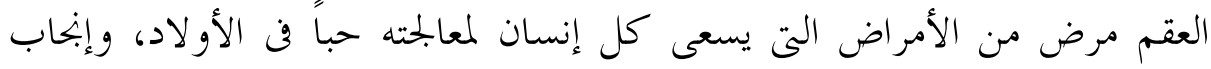

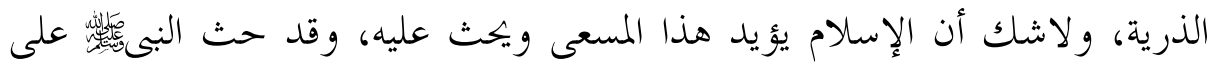

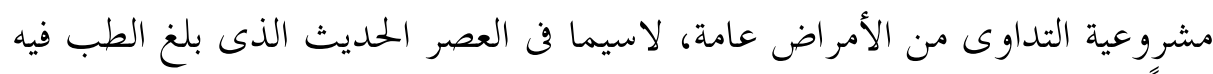

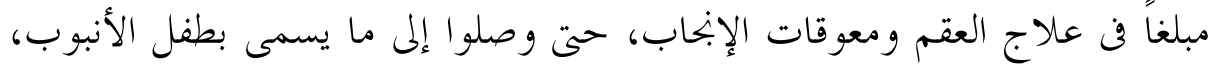

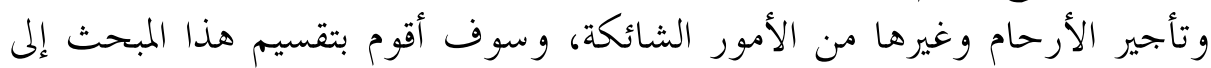

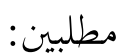

\section{المطلب الأول: حكم التداوى فى الإسلام}

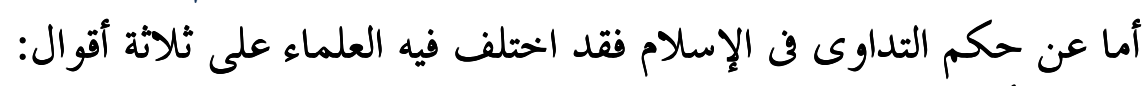

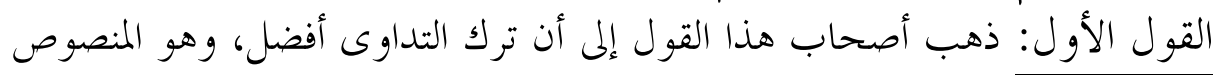

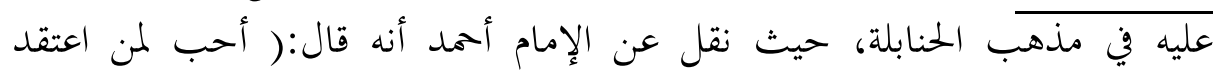

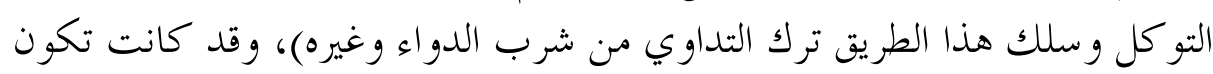

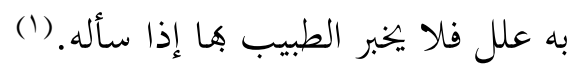

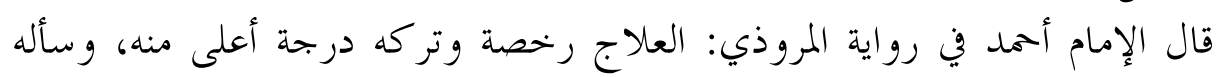

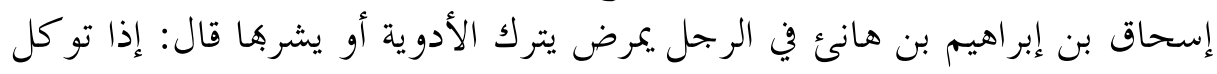

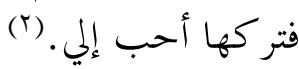
وقد عللو أرأيهم: بأن تركه تفضلًا والختيارًا لما اختاره الله، ورضاً بما قدر وتسليمًا او استدلو اعلى مذهبهم بأدلة منها:

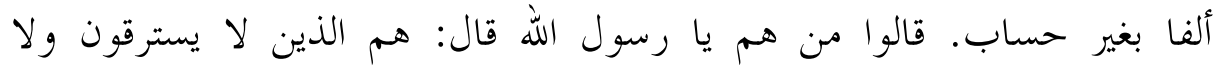

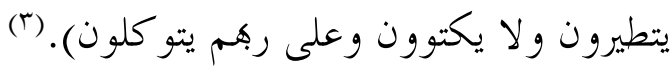

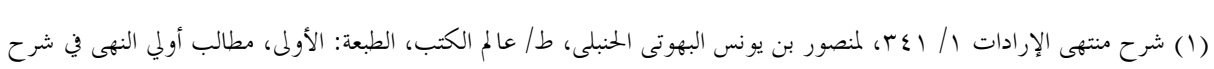

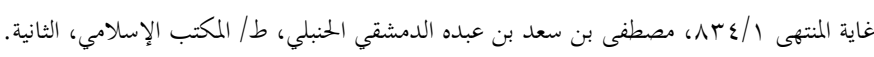

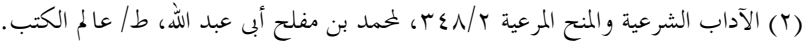

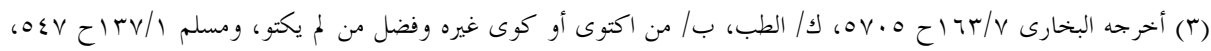

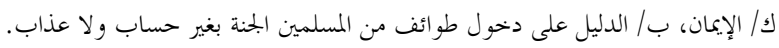




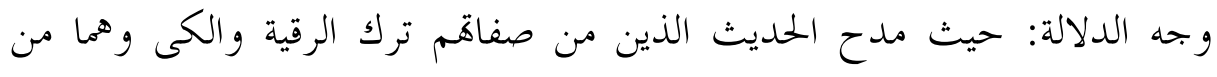

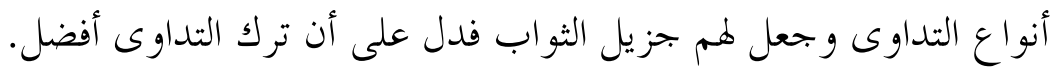
المناقشة:

نوقش هذا الدليل: بأن المدح الوارد في ترك الرقى المراد هـا الرقى التي هي من كلام

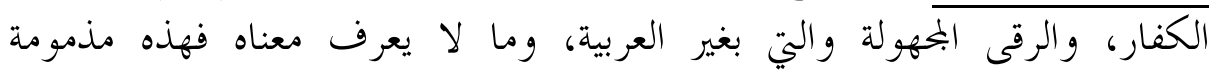

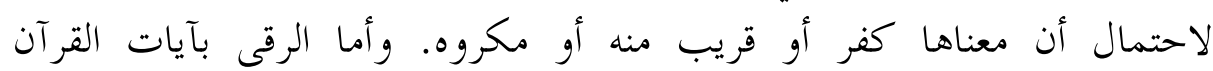
وبالأذكار المعروفة فلا هي فيه بل هو سنة.

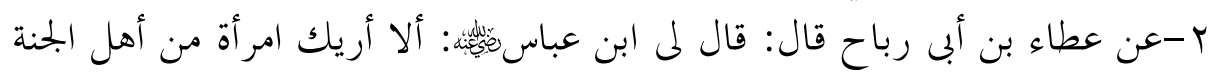

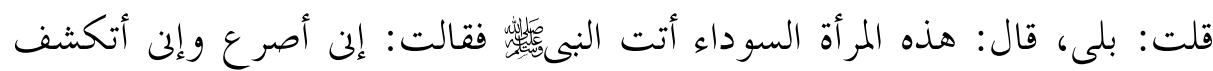

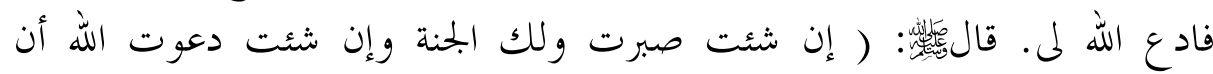

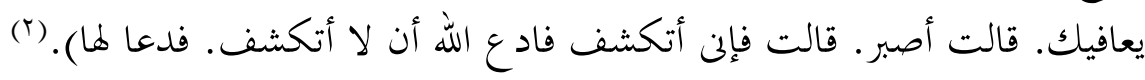

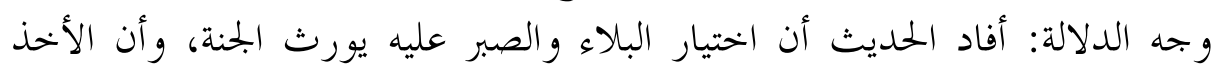

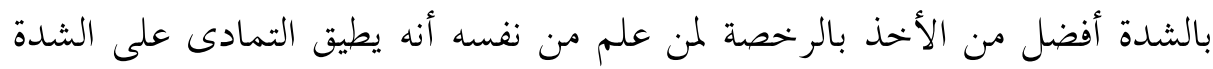

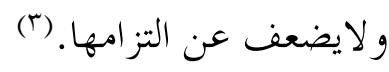

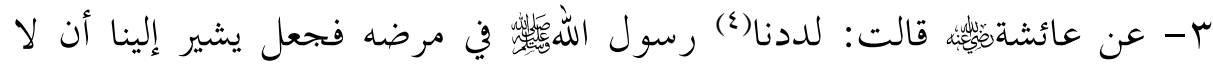

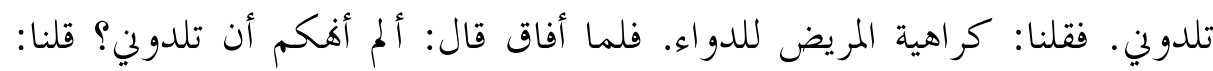

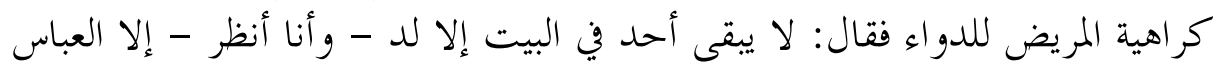

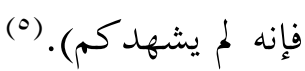

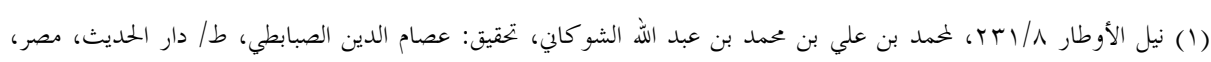

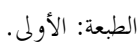

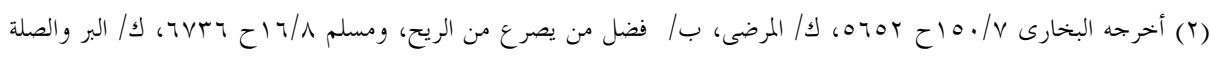

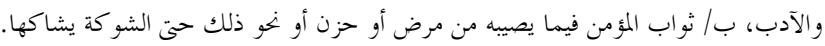

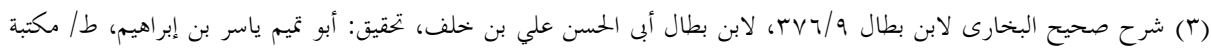
الرشد - السعودية، الرياض، الطبعة: الثانية.

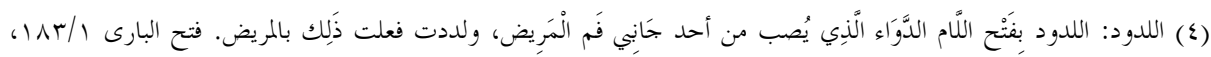

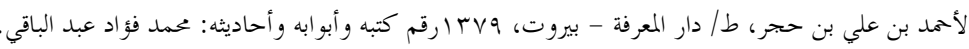

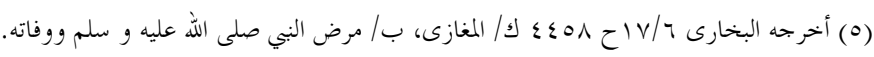




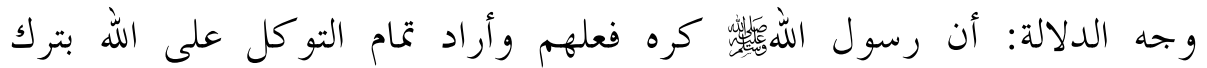

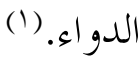

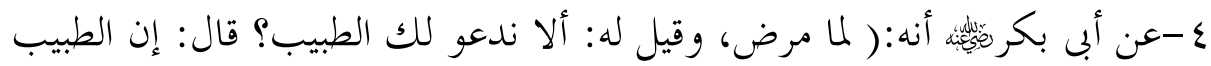

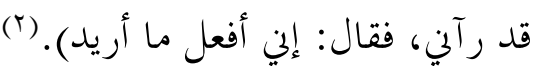

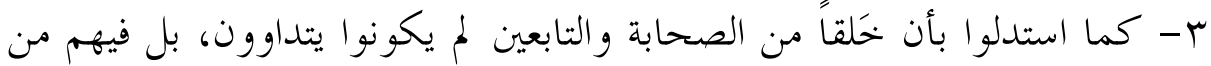

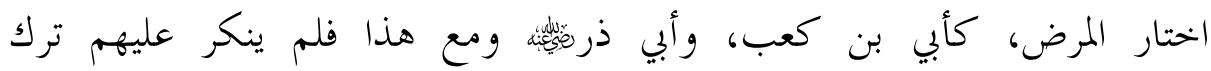

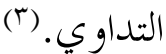

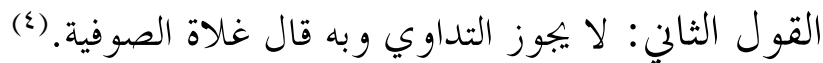

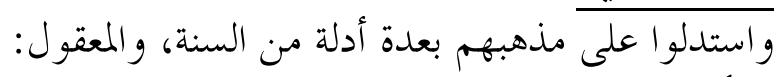
أولاً: دليلهم من السنة ملهن

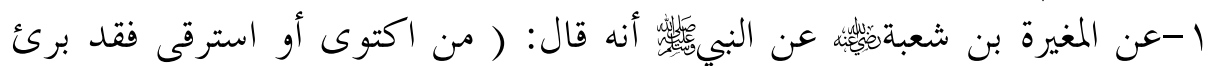

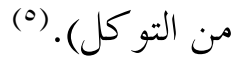

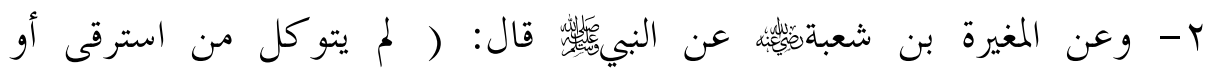

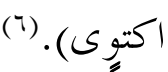

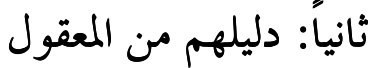

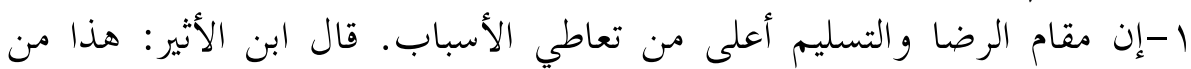

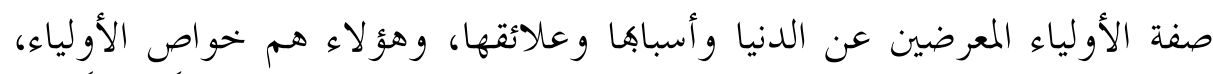

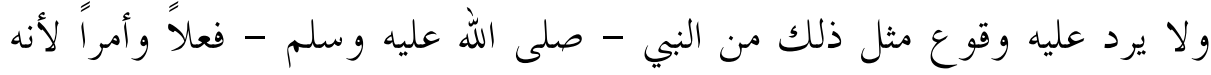

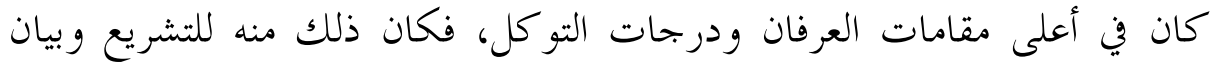

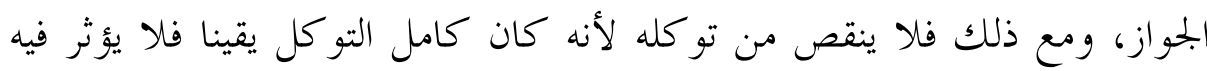

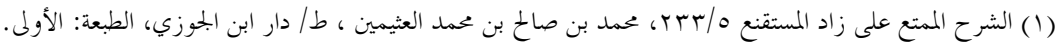

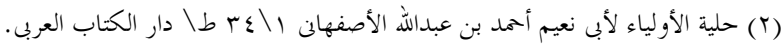

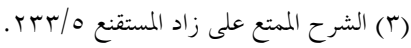

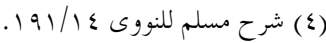

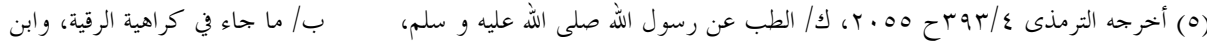

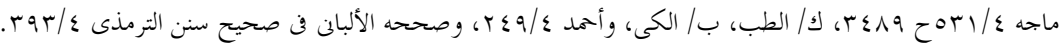

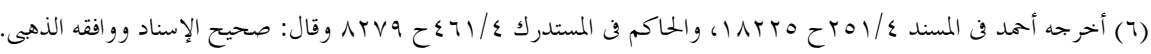


تعاطي الأسباب شيئا، بخلاف غيره ولو كان كثير التوكل، فكان من ترك الأسباب وفوض وأخلص أرفع مقاماً. (1)

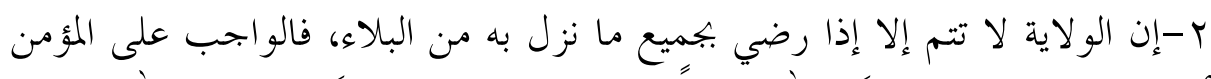

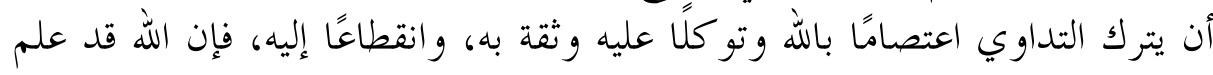

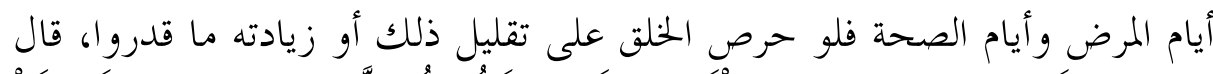

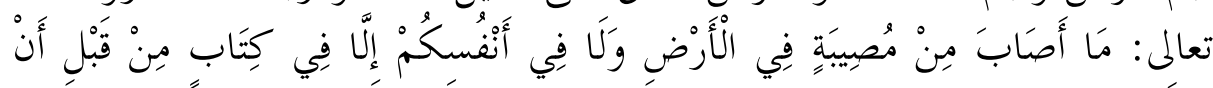

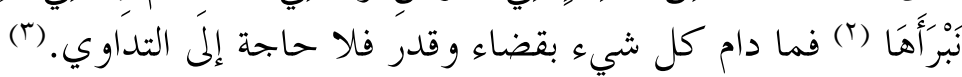

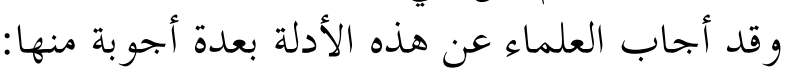

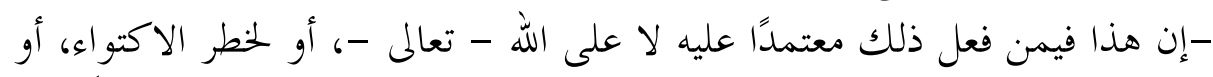

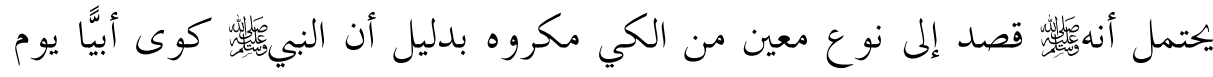

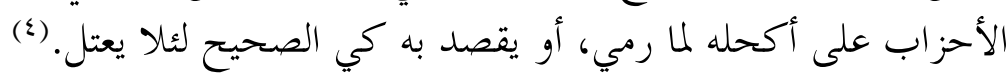

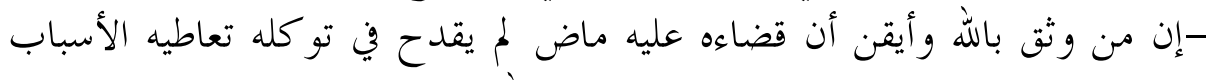

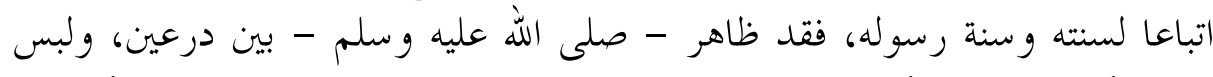

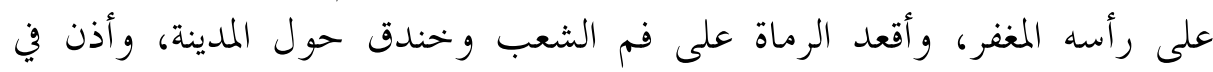

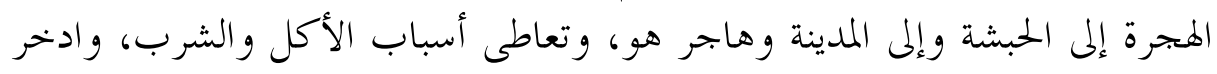

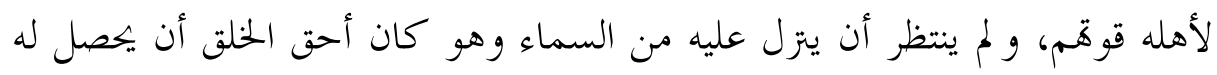

زلك. (0)

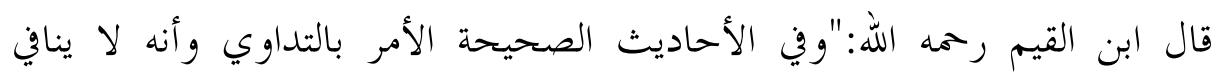

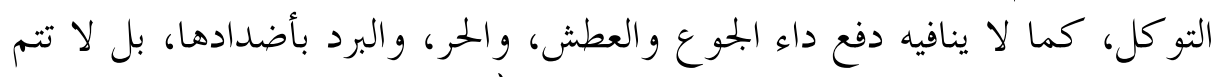

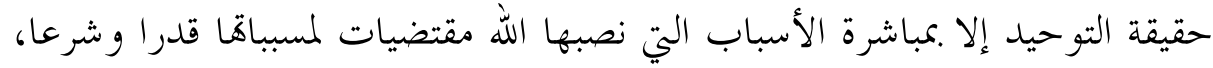

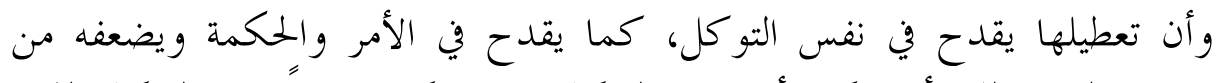

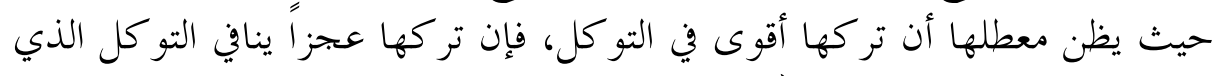

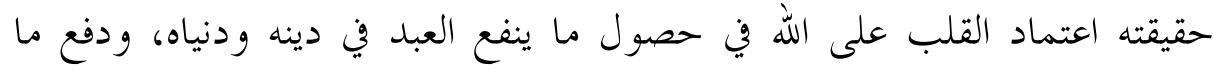

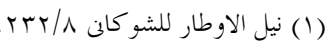

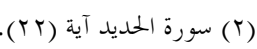

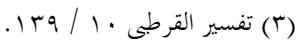

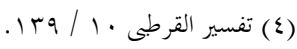

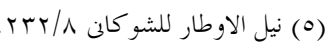


يضره في دينه ودنياه، ولا بد مع هذا الاعتماد من مباشرة الأسباب وإلا كان معطلا

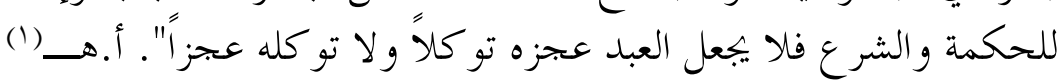

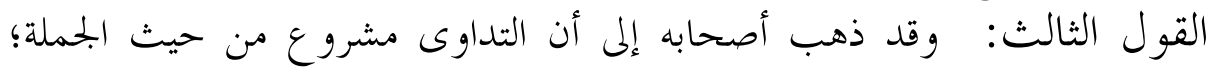

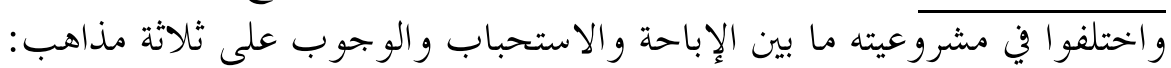

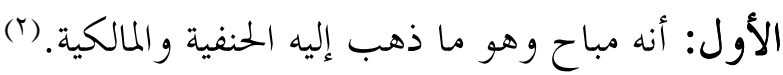

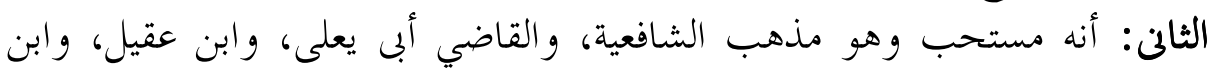

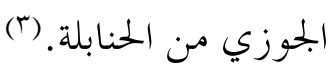

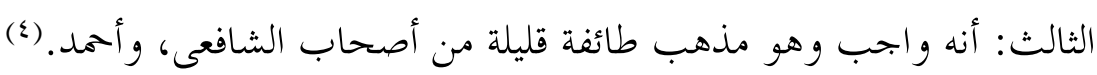

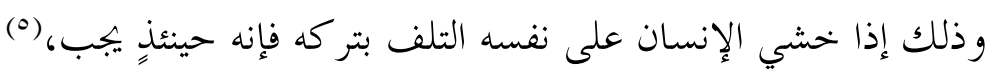

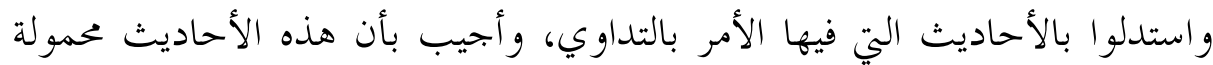

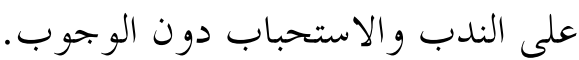

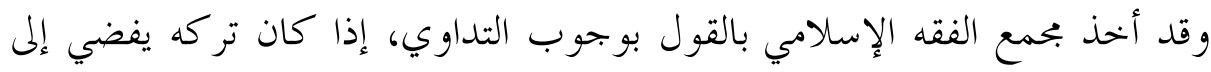

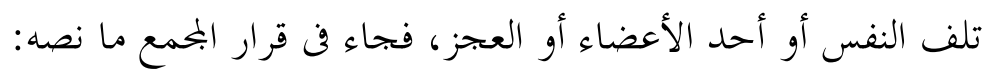

ط) (1) زاد المعاد في هدي خير العباد ع/ع ا، لمحمد بن أبي بكر بن أيوب ابن قيم الجوزية

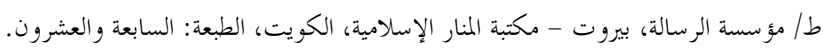

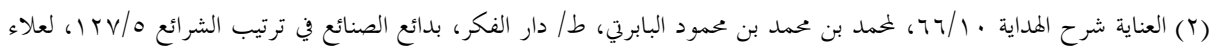

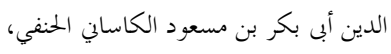

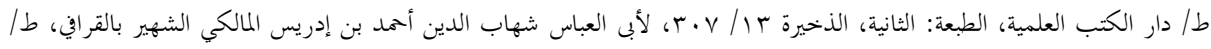

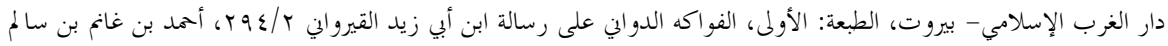

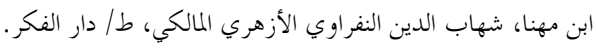

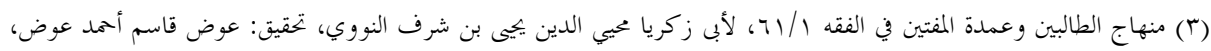

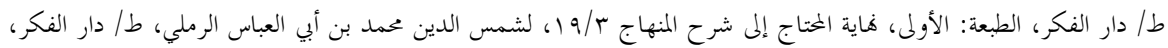
بيروت،

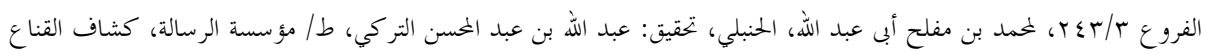

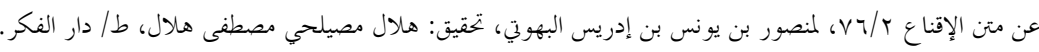

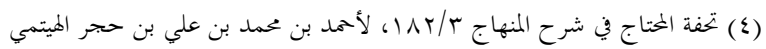

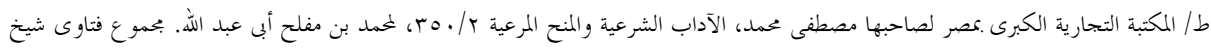

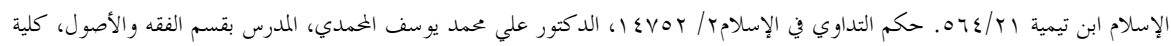

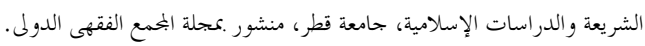

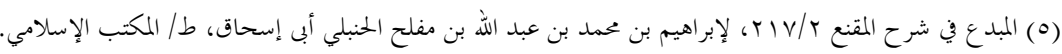


"الأصل في حكم التداوي أنه مشروع، لما ورد في شأنه في القرآن الكريم والسنة

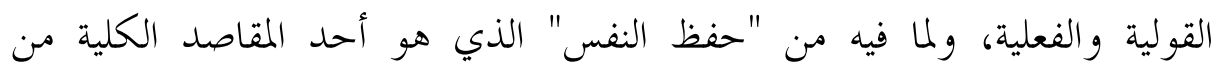

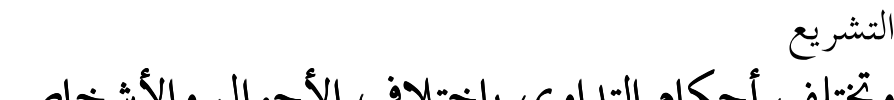
وتختلف أحكامٍ التداوي باختلاف الأحوال والاشخاص :

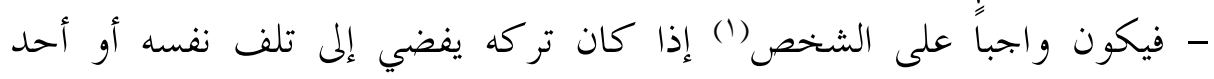

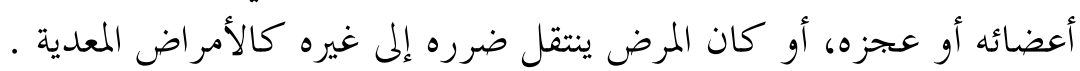

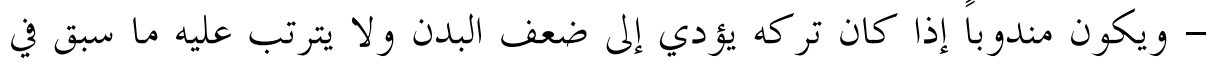

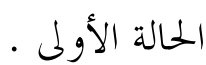

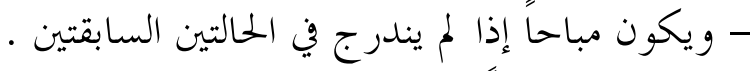

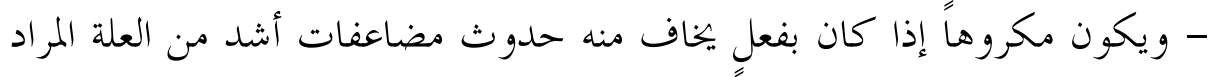

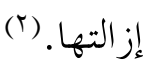

وما ذهب إليه البممع الفقهى موافق لما رجحه شيخ الإسلام تقى الدين ابن تيمية

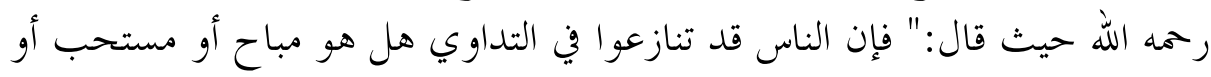

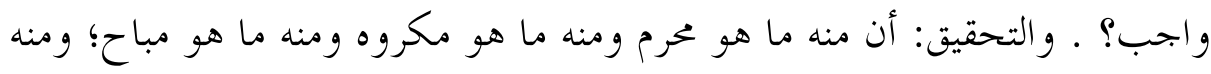

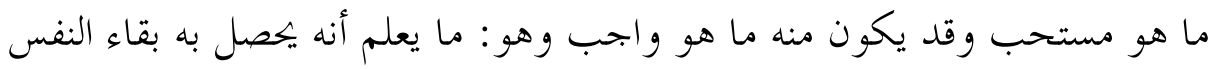

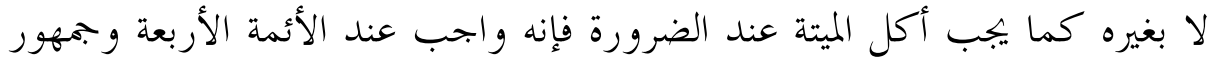

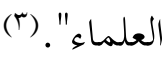
ولقد حدد الأطباء فن العصر الحديث الحالات التي يجب التداوى منها والحالات التى

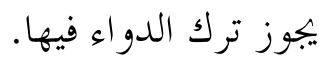

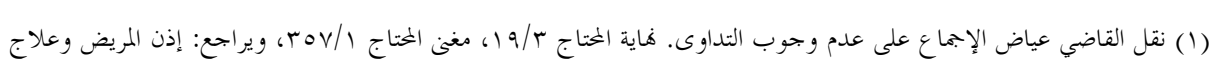

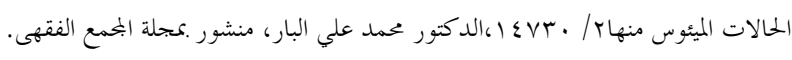

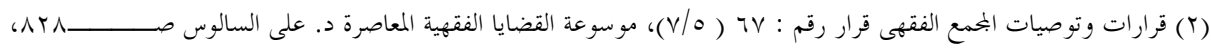
طا مؤسسة الريان. الطبعة الحادية عشرة.

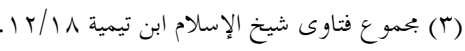




\section{الحالات التى يجب فيها التداوي:}

يقول الطبيب محمد على البار (1) ا- يبدو و الله أعلم أن هناك بعض الحلى البار الات التي يجب فيها التداوي وذلك: مثال

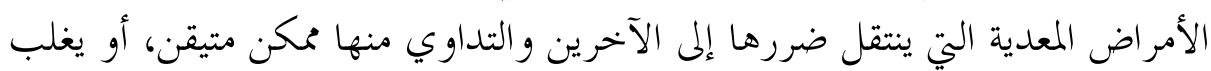

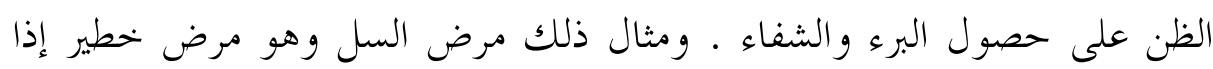

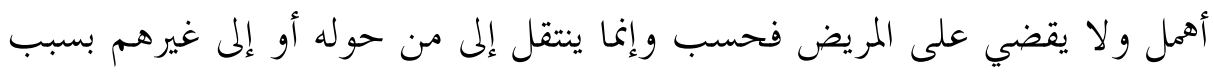

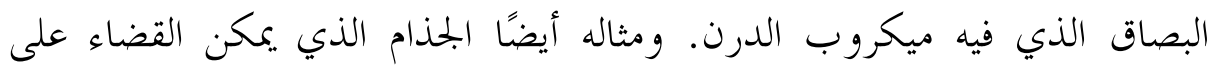

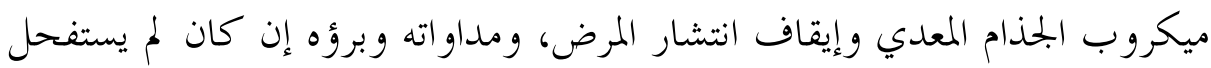

وهناك العديد من الأمراض التي تفرض الدول و المختمعات القيود على المصاب هـا

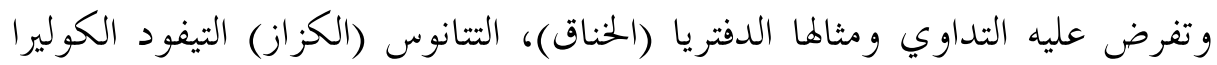

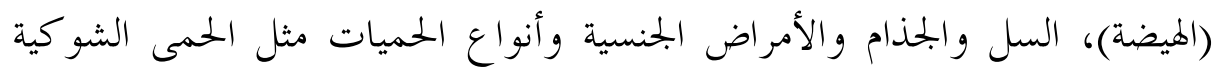
و الملاريا و التيفوس... إلخ. الخ. ورغم أن بعض الأمراض المعدية لا علاج لها إلا أن وسائل الوقاية والتطعيم تمنع من

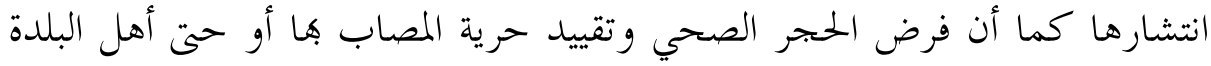

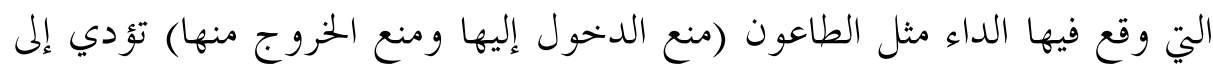
تضييق نطاق انتشار الوباء. وفي هذه الحالات جميعًا يجب التداوي للأسباء أنساب التالية:

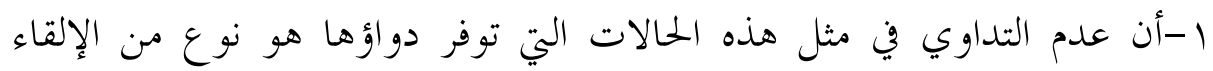
بالنفس إلى التهلكة وهو أمر منهي.

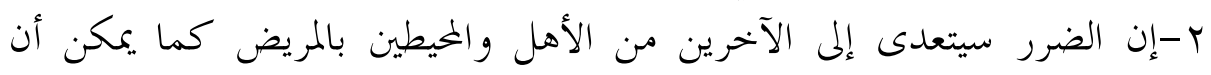

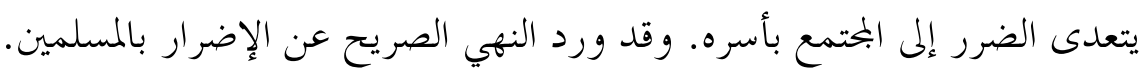

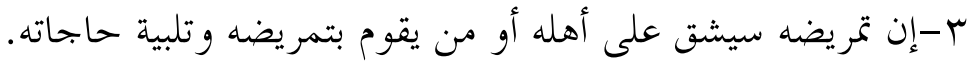

(1) الدكتور محمد علي البار مستشار قسم الطب الإسلامي، بكر كز الملك فهد للبحوث الطبية،

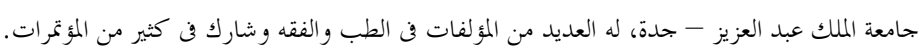




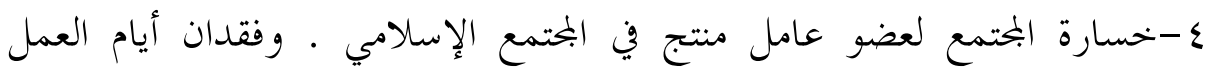

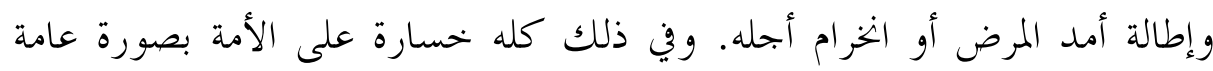

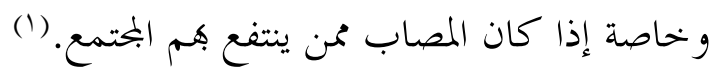
الحالات التى يجوز فيها عدم التداوي

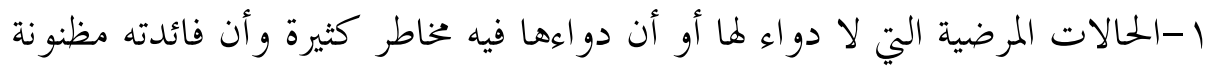

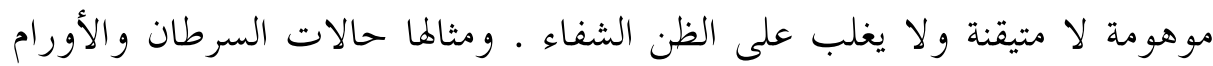

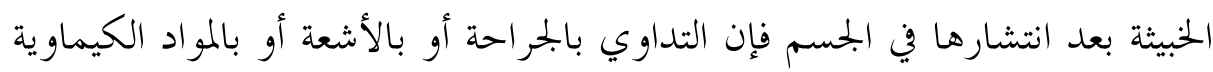

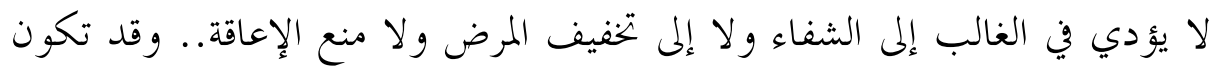

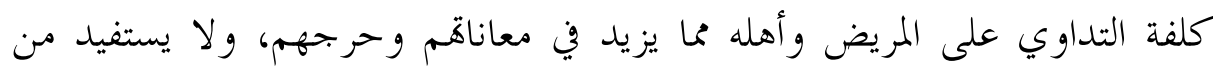
هذه المحاولات إلا المستشفيات وأصحابها.

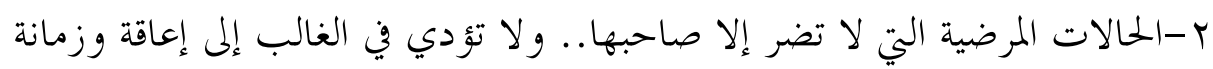

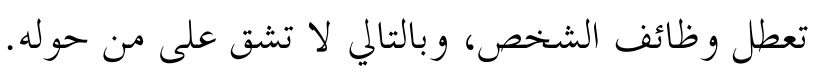

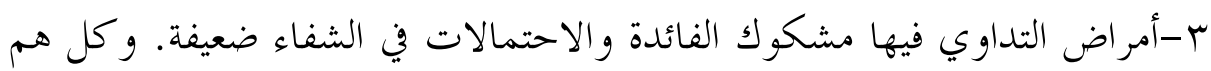

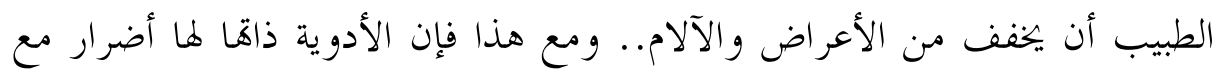

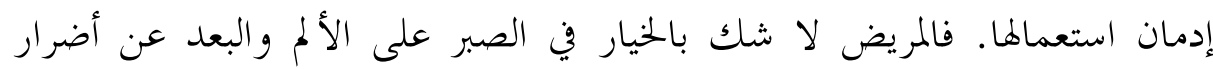

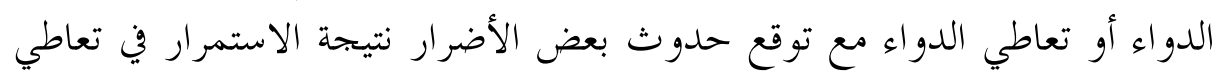

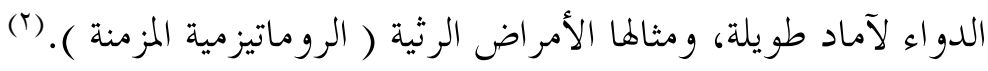
الأدلة على مشروعية التداوي: استدِل الجمهور على مشروعية التداوى بأدلة من القرآن، وآلى والسنة، والمعقول:

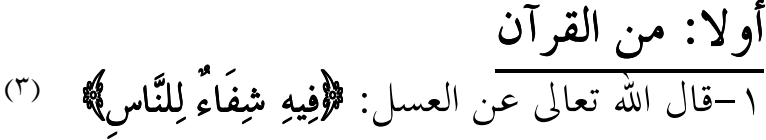

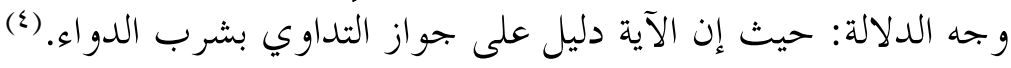

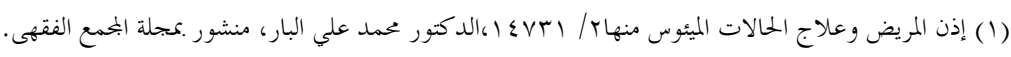

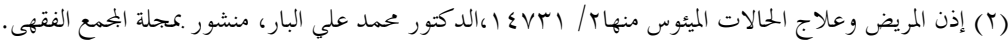

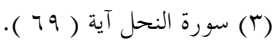

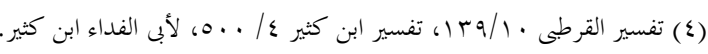




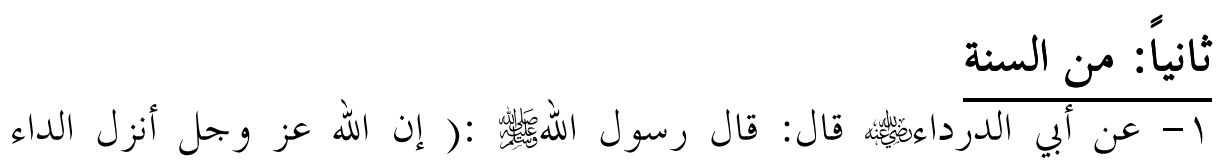

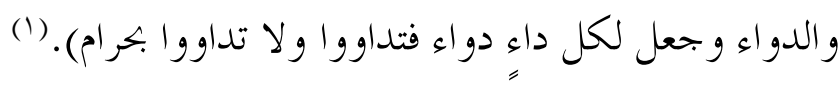

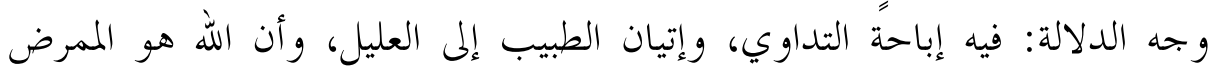

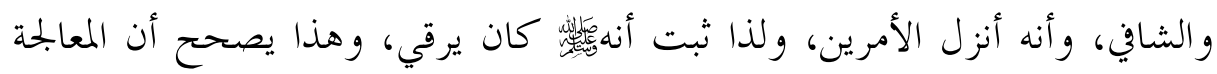

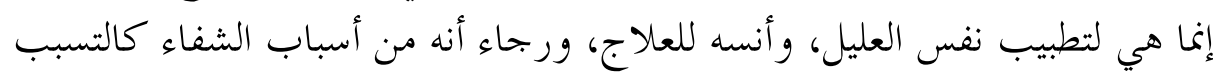

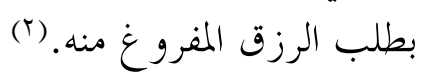

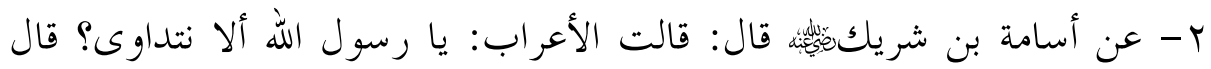

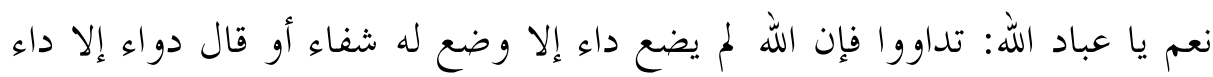

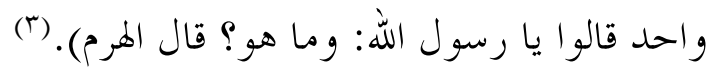

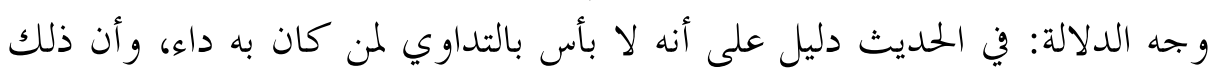

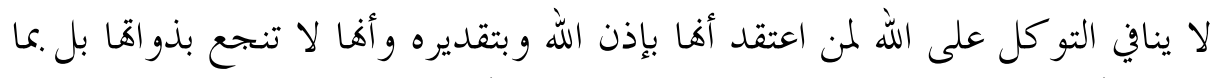

قدره الله فيها، وأن الدواء قد ينقلب داء إذب إذا قدر الله ذلك.

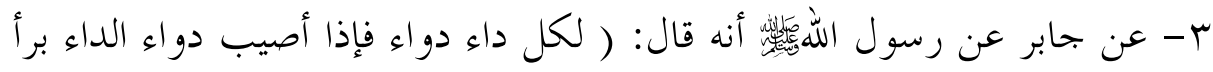

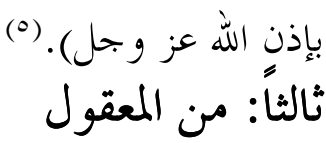

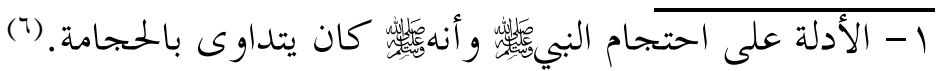

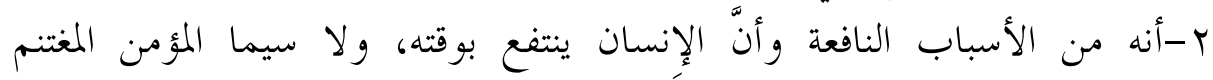
للأوقات، كل ساعة تمر عليه تنفعه.

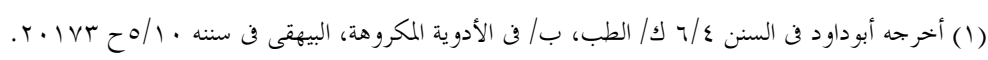

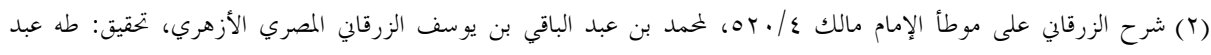

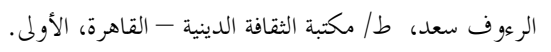

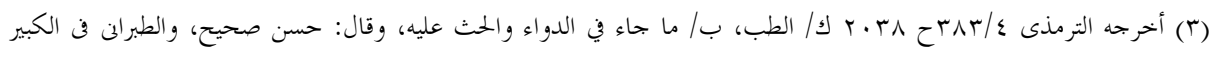


r-المريض يكون ضيق النفس، لا يقوم بما ينبغي أن يقوم به من الطاعات، وإذا بنا

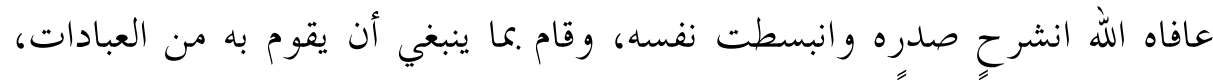

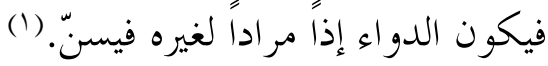

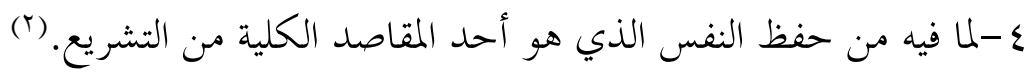

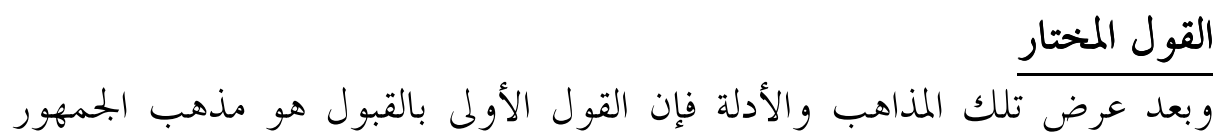

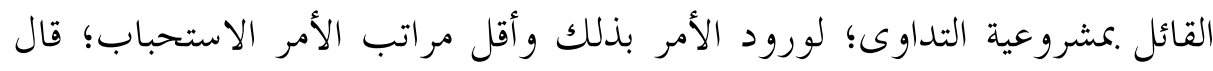

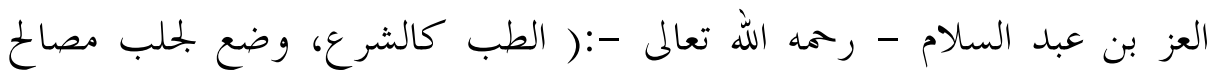

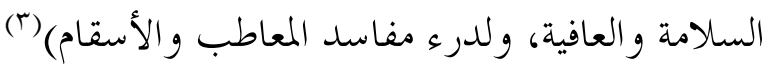

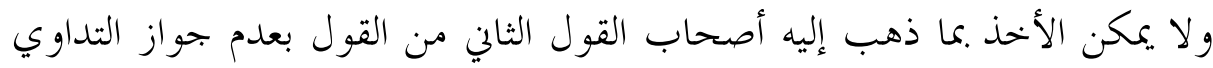

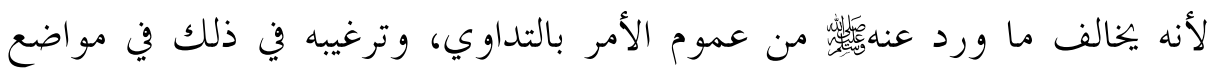

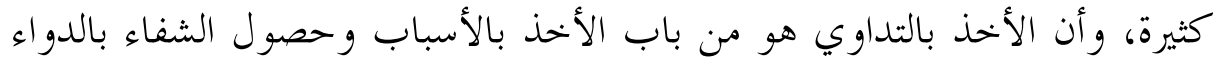

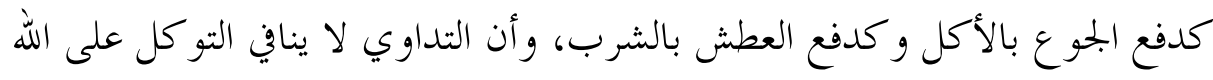

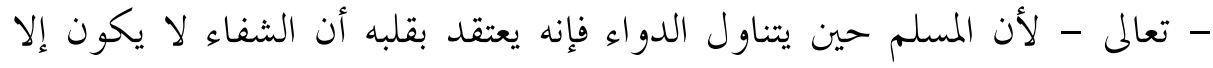

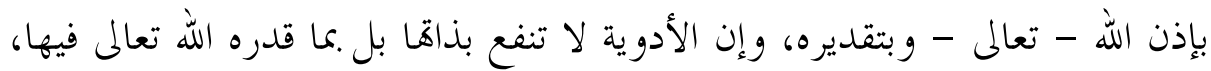

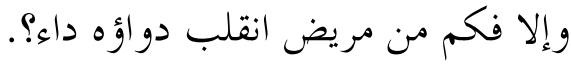

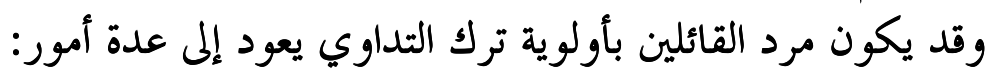

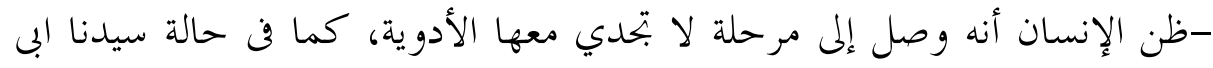

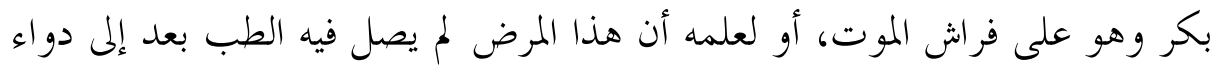

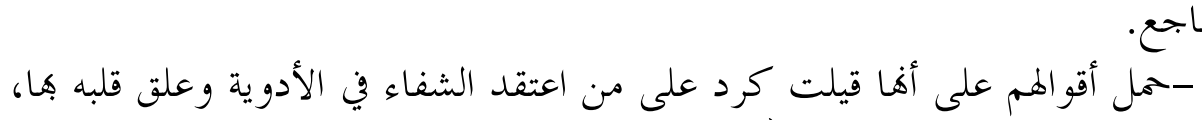

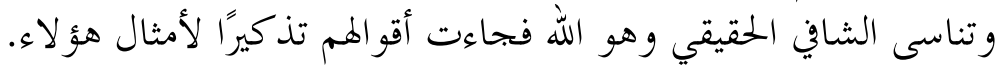

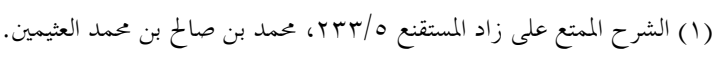

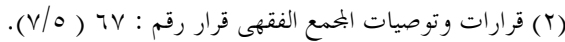

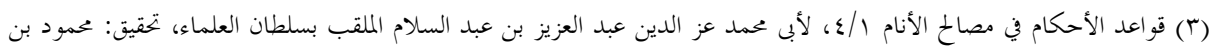
التلاميد الشنقيطي، ط/ دار المعارف بيروت - لبنان. 
-إن من قوي تو كله فالترك له أولى ومن ضعفت نفسه وقل صبره فالمداواة له أفضل. (1) و الله أعلم. قوي توله

\section{المطلب الثانى: حكم التداوى بالمحرمات}

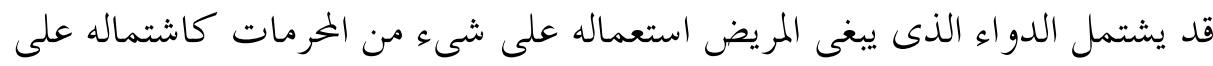

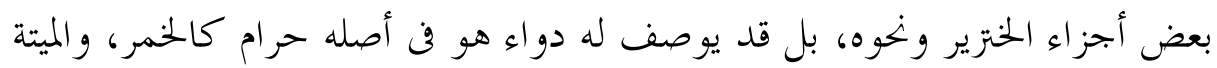

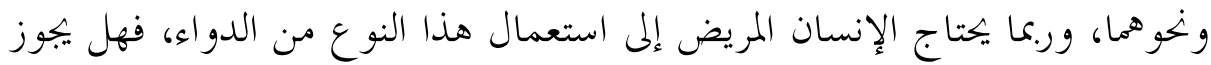

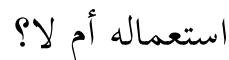

\section{اختلف الفقهاء في حكم التداوي بالمحرمات على ثلاثة أقوال:}

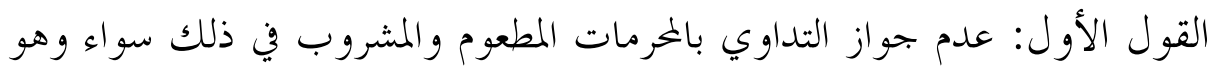

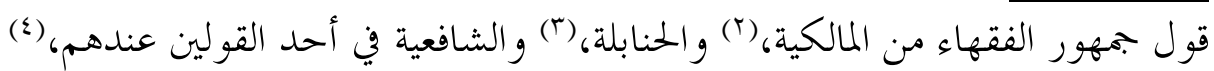

القول الثانى: جواز التداوي بالمرمات من غير قيد، وهو مذهبب الشافعية في الأصح

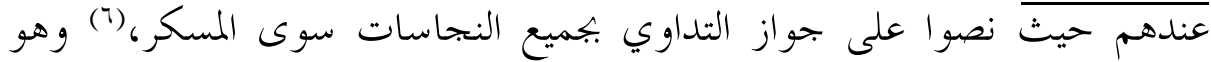
مذهب الظاهرية عند الاضطر ار إليه.

(1) البحموع شرح المهذب //7 • 1، لأبى زكريا محيي الدين يجيى بن شرف النووي، ط/ دار الفكر.

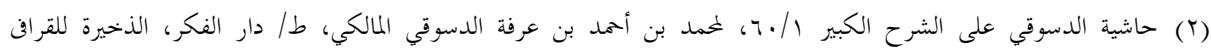
$r \cdot N / 1 T$

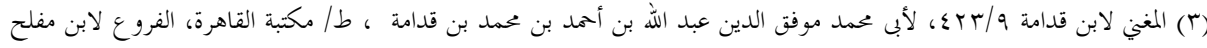
. $T \leqslant Y / r$

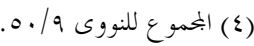

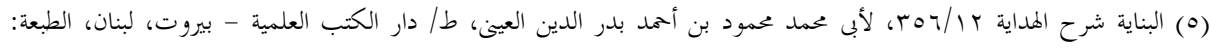
الأولى.

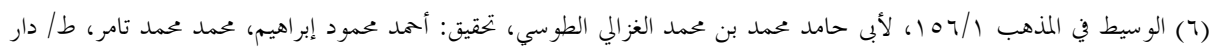

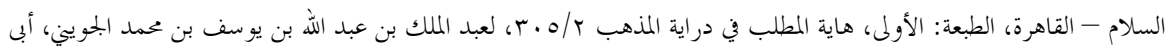


القول الثالث: جواز التداوي بالمحرم إذا تيقن طريقًا للشفاء، و لم يبجد ما يقوم مقامه

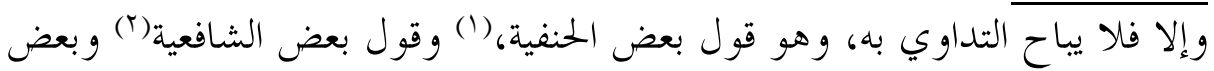

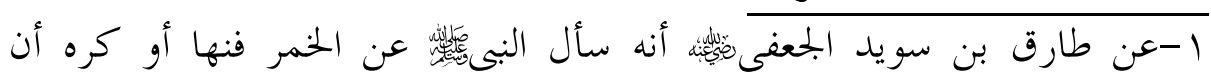

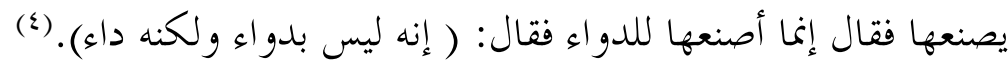

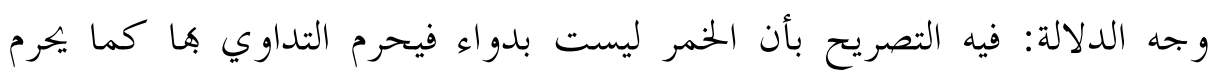

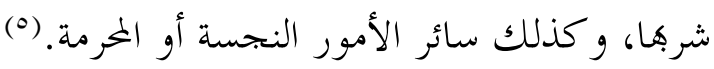

المناقشة:

الحديث ليس فيه حجة؛ لأن فيه أن الخمر ليست دواء، و إذا ليست دواء فلا خلاف

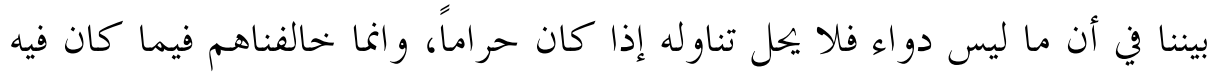

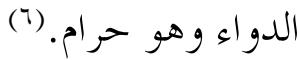

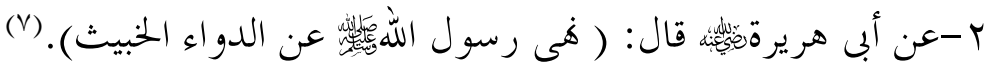
وجه الدلالة: في الحديث تحريم التداوي بكل خبيث، ولا ريب أن الحرام و النجس

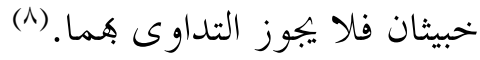

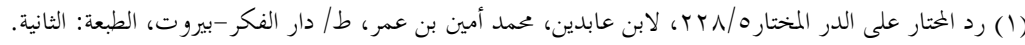

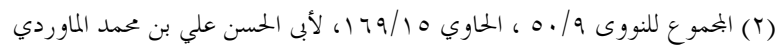

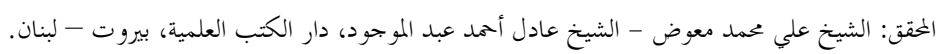

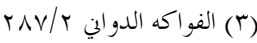

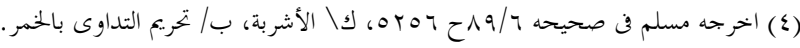

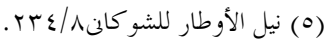

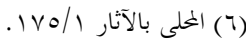

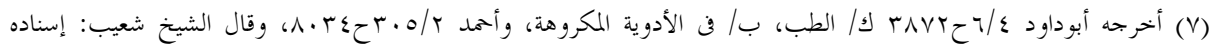




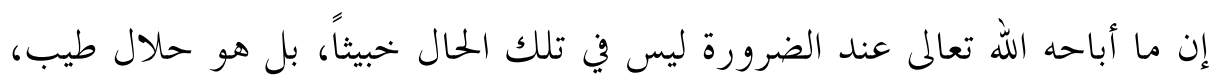

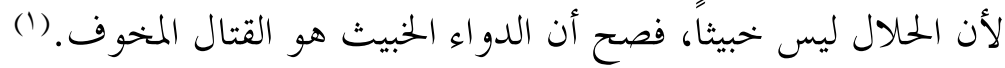

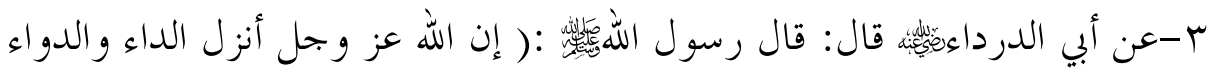

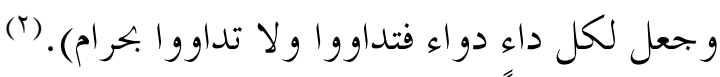
وجه الدلالة: في الحديث النهى عن التداوى بالحرام نصاً والنهى للتحريم كما يقول

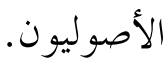

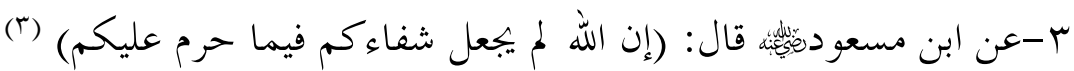
وجه الدلالة: فيه دليل على نزع الشفاء من الخرمات حيث لم ميجعل الله فيه شفاء

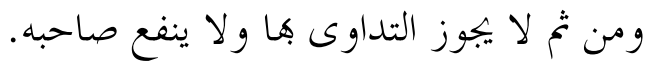

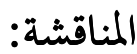

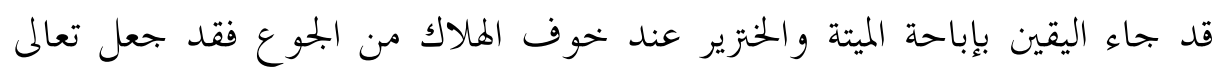

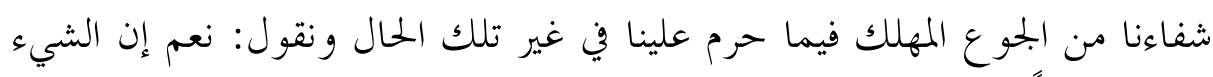

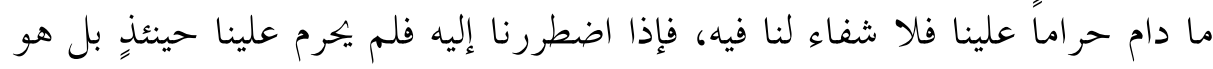

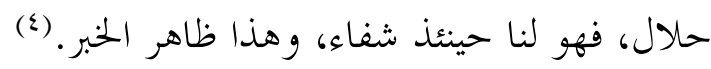

وأجيب: بأن المرض ليس من الضرورات التي تبيح المخظورات، كما في تناول

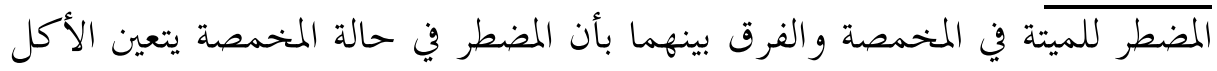

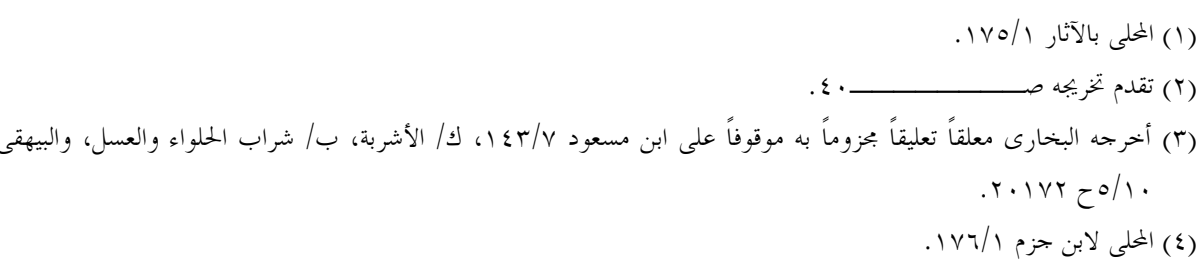


طريقًا لإنقاذ حياته بخلاف حالة المرض فإن هذه المحرمات لا يتعين تناوها طريقًا

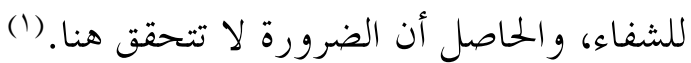

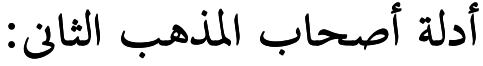
واستدلو أعلى مذهبهم بالقِ آلمهب آناف، والسنة، والقو اعد، والمعقول:

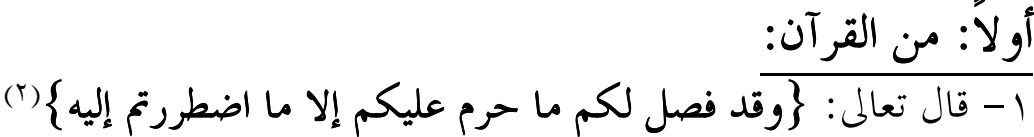

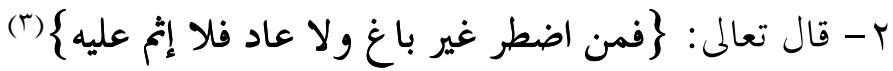

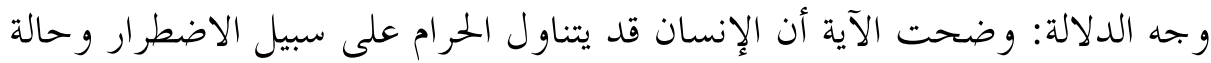

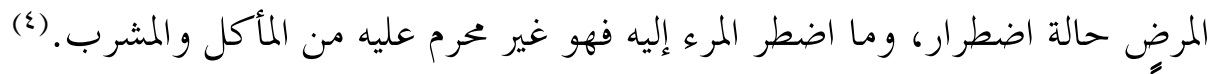

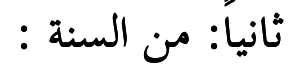

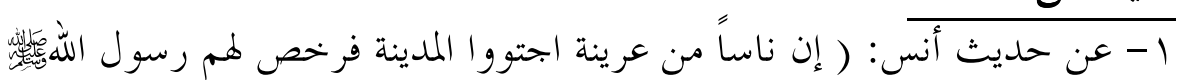

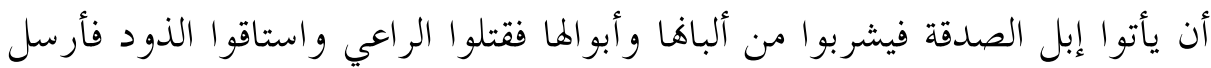

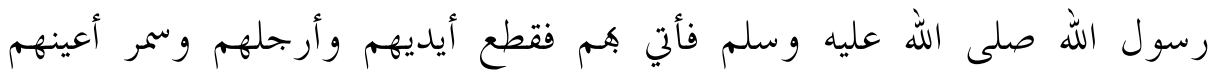

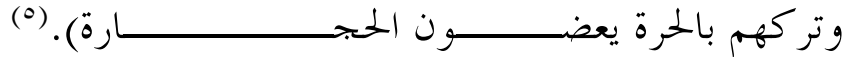

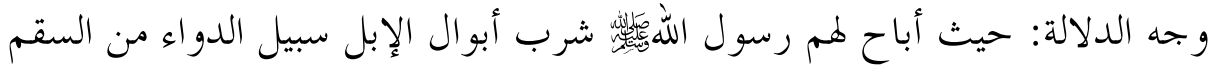

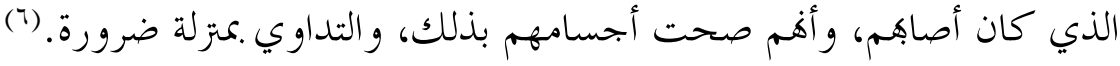

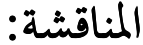

نوقش الاستدلال هذا الحديث بأن التحليل يستلزم الطهارة، فتحليل التداوي ها دليل

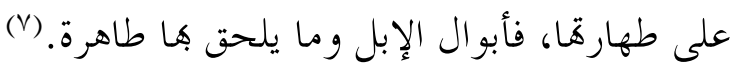

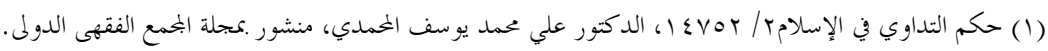

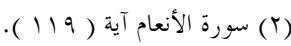

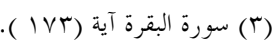

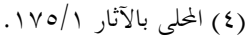

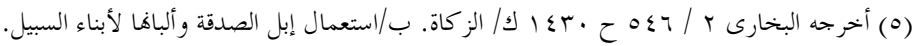

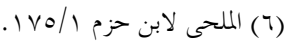

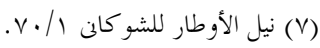

rTV 
وأجيب عنه بأنه محمول على حالة الاختيار، وأما في الضرورة فلا يكون حراماً

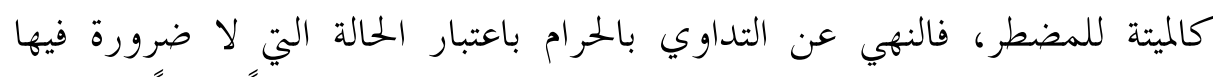

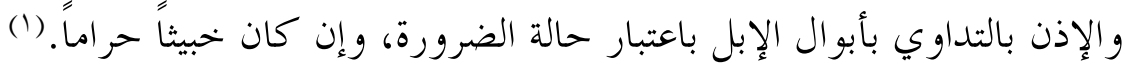

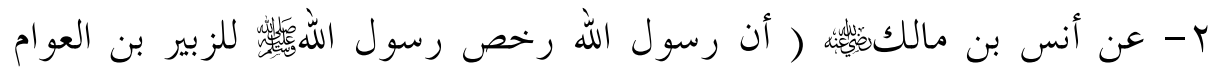

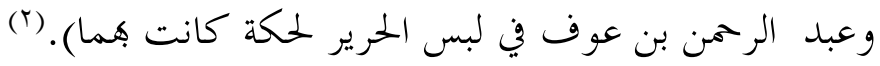

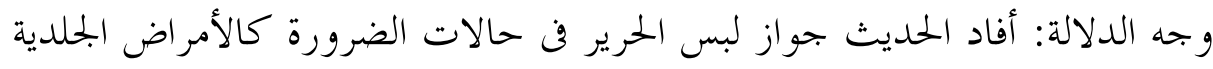

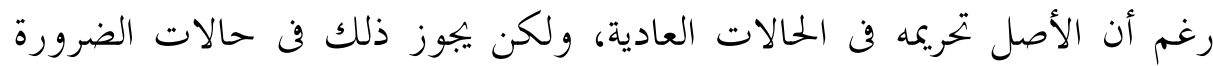

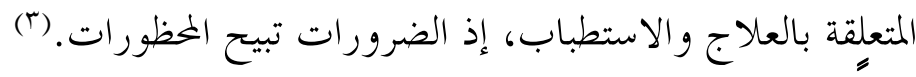
ثالثاً: القواعد الفقهية:

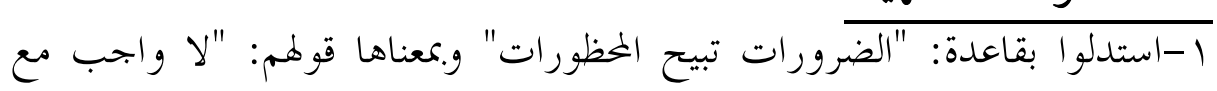

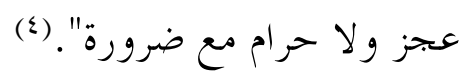

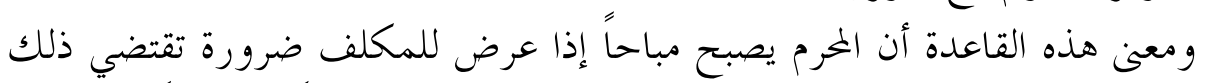

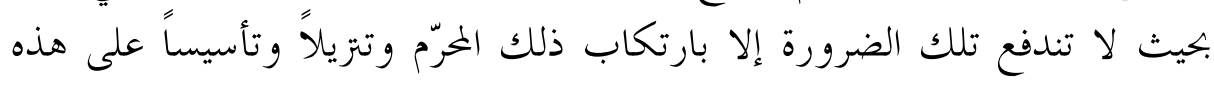

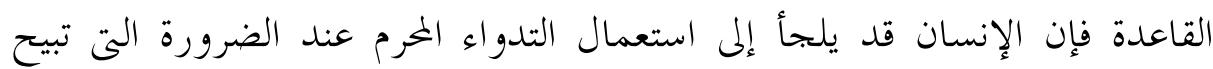

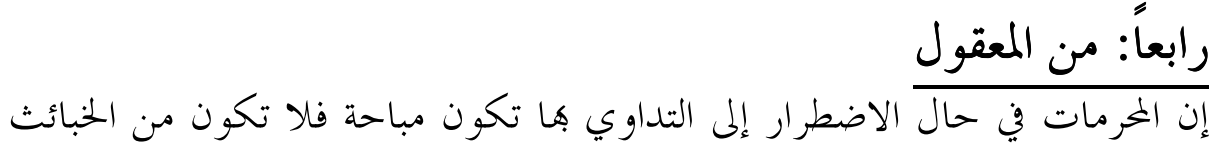

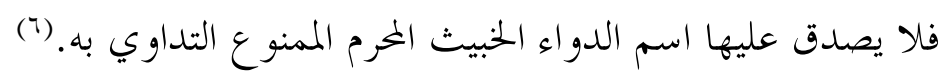

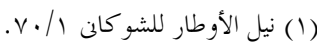

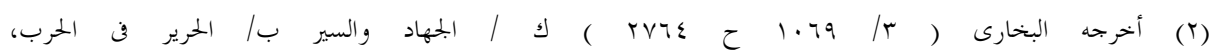

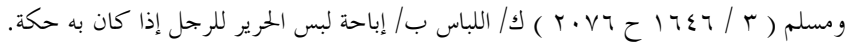

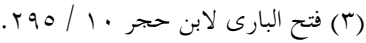

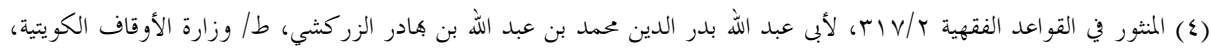

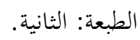

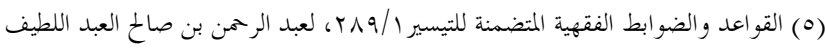
ط/ عمادة البحث العلمي بالجامعة الإسلامية، المدينة المنورة، الطبعة الأولى.

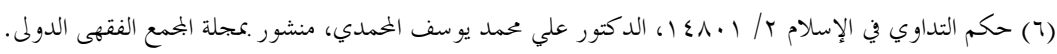


أدلة أصحاب المذهب الثالث:

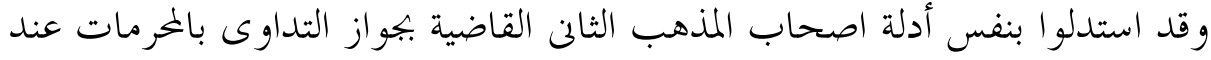

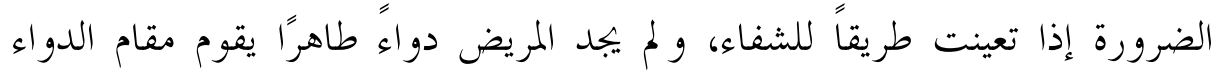

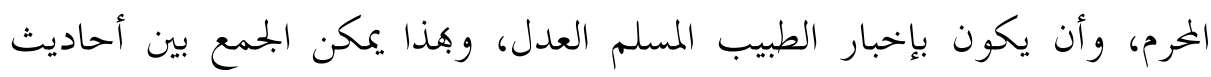
النهي وبين حديث العرنيين. (1) القول المختار

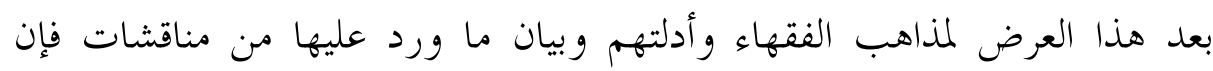

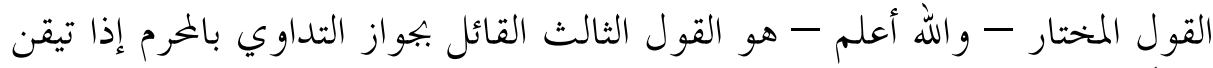

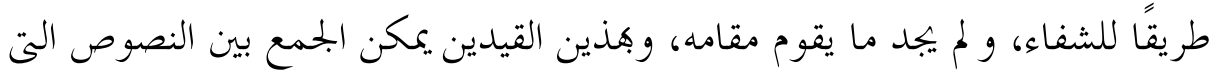

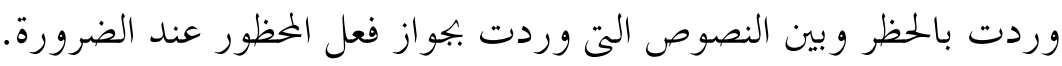
وبالله التوفيق 


\section{الخاتمبــة}

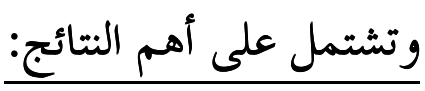

1-اهتم الأطباء عند تعريفهم للعقم بذكر مدة محددة يصدق بعدها ولفي وصف العقم؛

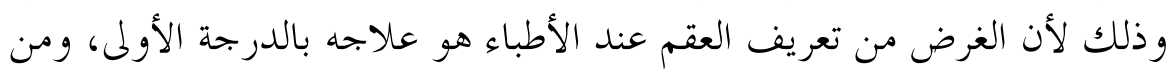

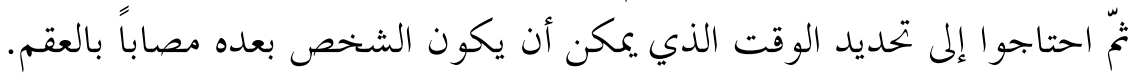

r - لم يؤثر تعريف جامع مانع للعقم في كتب الفقهاء وذلك بسبب عدم إمكانية

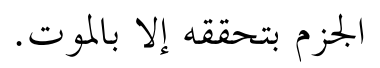

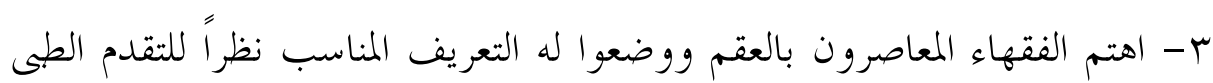

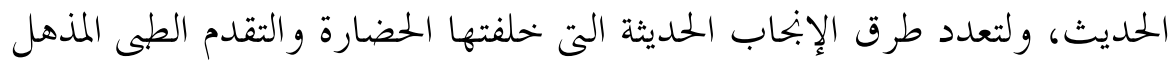

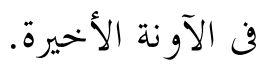
ع -تعددت أسباب العقم ما بين أسباب عامة، وأسباب طبية خاصة. ه- العقم مرض من الأمراض التى يسعى كل إنسان لمعالجته حباً في الأولاد، وإبحاب الذرية، والإسلام يؤيد هذا المسعى ويحث علئ.

צ-اختلف العلماء في حكم التداوى على خمسة أقوال المختار منها مشروعية التداوى للنصوص الدالة على ذلك.

V-اختلف الفقهاء في حكم التداوى بالمرمات على ثلاثة أقوال المختار منها جواز

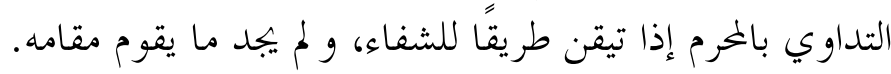




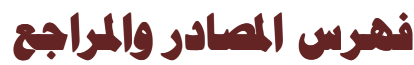

\section{أولاً: القرآن الكريع وعلومه:}

1-الإتقان في علوم القر آن للحافظ جلال الدين عبد الرحمن السيوطى ت 119 هـ

$$
\text { ط/ دار الكتب العلمية. - مار. }
$$

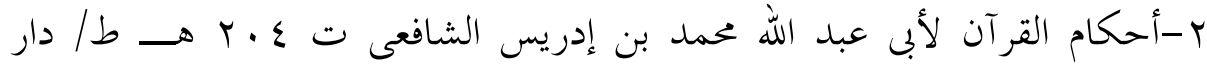

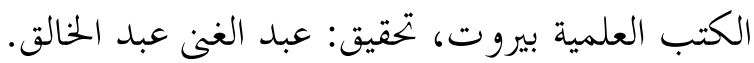

r-أحكام القرآن لأحمد بن على الرازى الجصاص ت . • بrهــ ط/ دار الفكر

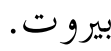

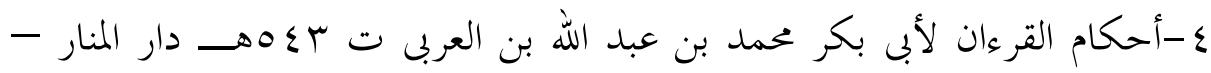

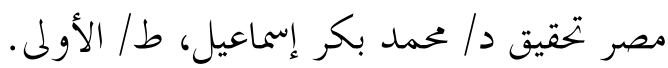

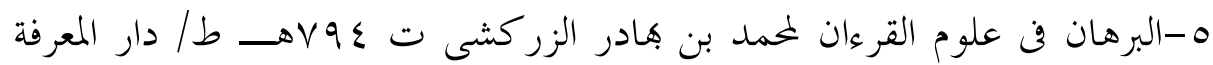

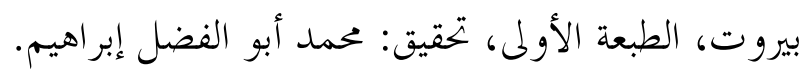

7- تفسير ابن كثير، لأبى الفداء إسماعيل بن عمر بن كثير، تحقيق: محمد حسين

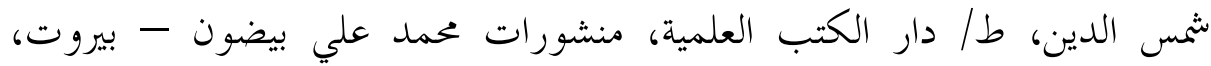

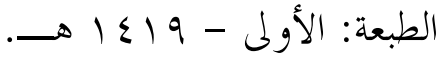

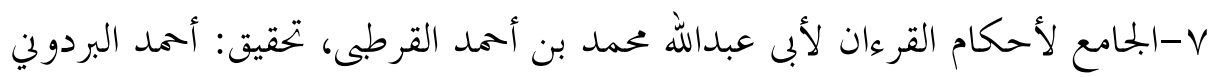

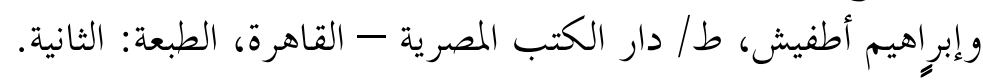

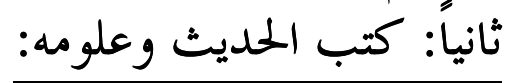

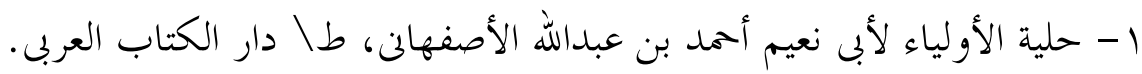

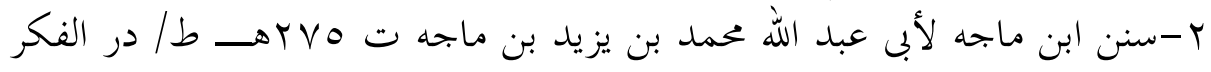
بيروت تحقيق محمد فؤاد عبد الباقى. 


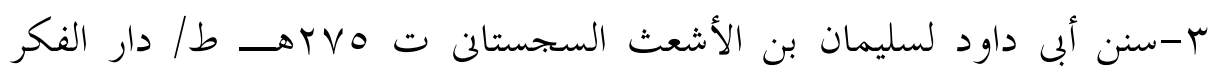

$$
\text { تحقيق محمد محى الدين عبد الحميد النيد. }
$$

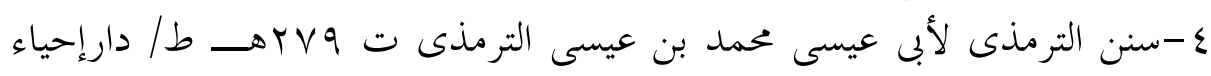

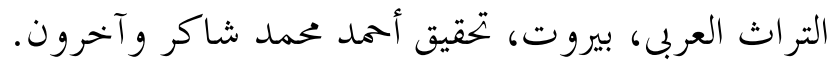

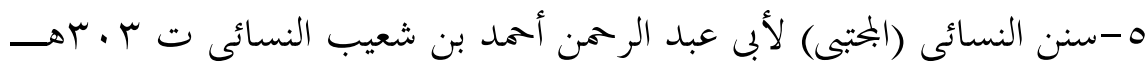

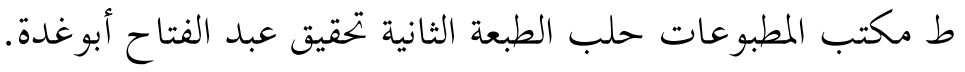

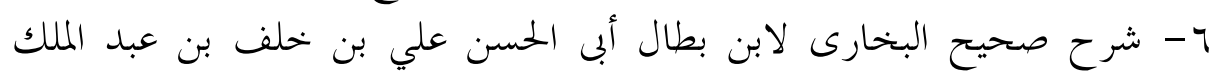

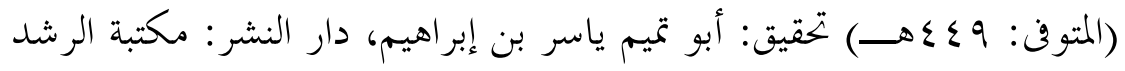

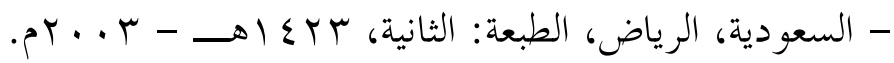

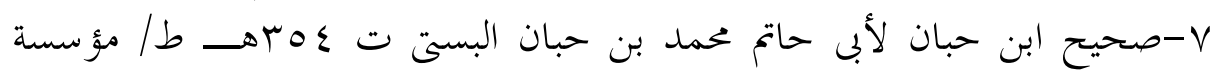

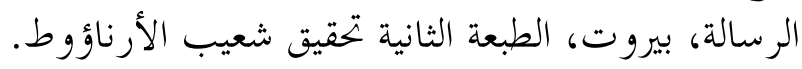

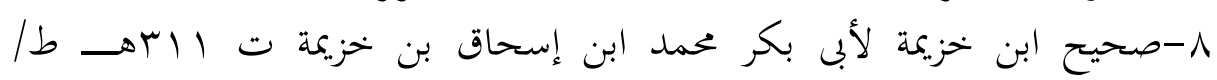

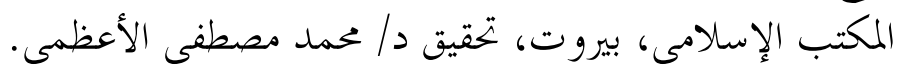

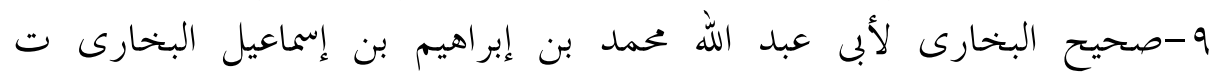

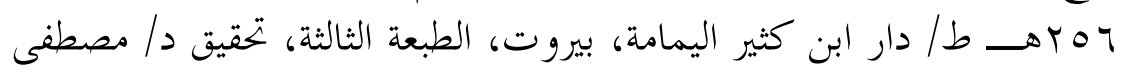

$$
\begin{aligned}
& \text { ديب البغا. }
\end{aligned}
$$

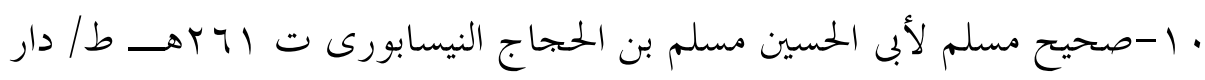

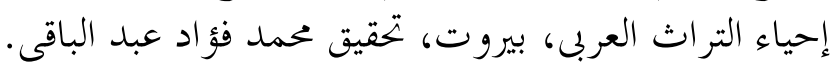

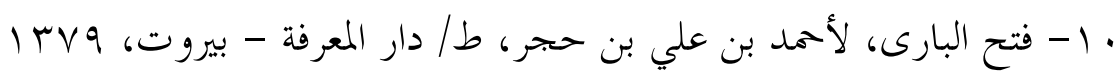

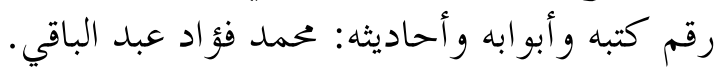

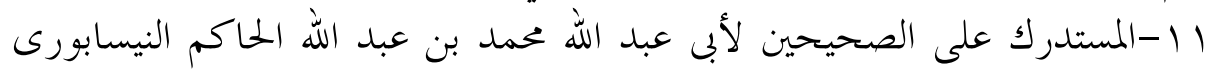

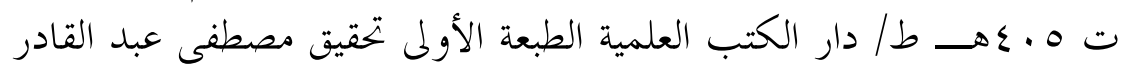

$$
\text { عطا. }
$$

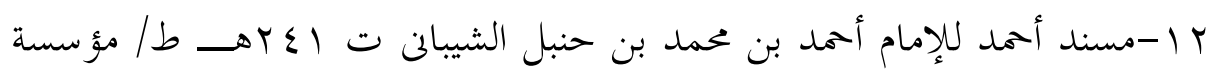

$$
\text { قرطبة. }
$$

rا - نيل الأوطار، لممد بن علي بن محمد بن عبد الله الشوكاني، تحقيق: عصام

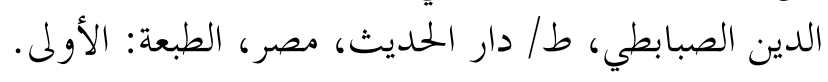




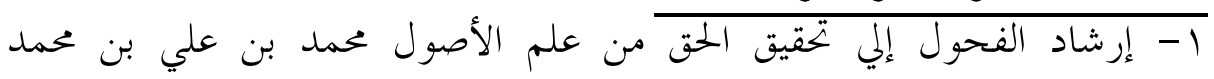

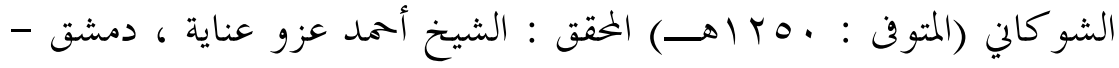

$$
\text { الناشر : دار الكتاب العربي. }
$$

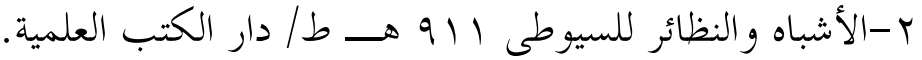

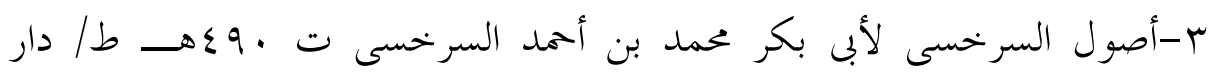

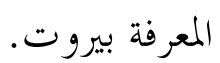

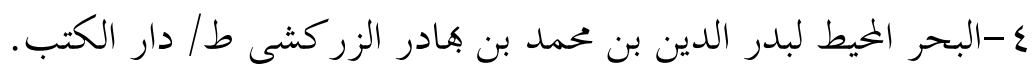

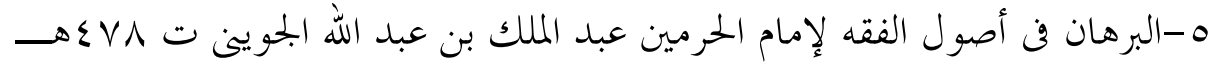

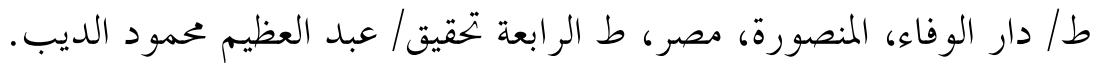

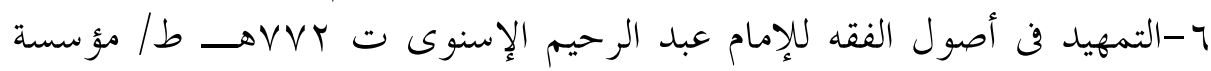

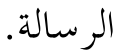

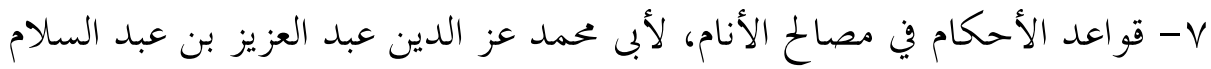

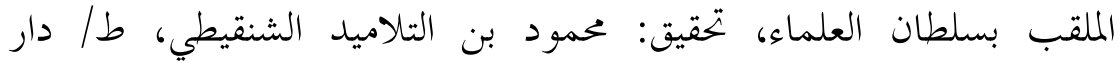

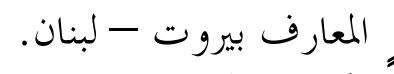

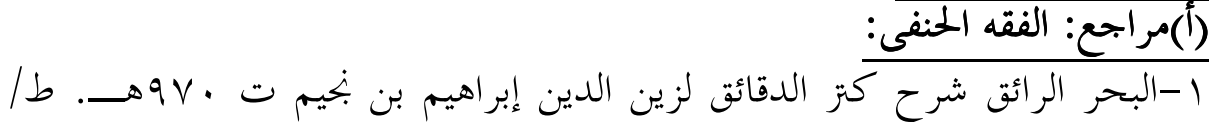

$$
\text { دار الكتاب الإسلامي. }
$$

Y-بدائع الصنائع في ترتيب الشرائع لأبلى بكر مسعود بكن أحمد الكاسان. ط ط/ دار

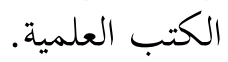

r-بتبين الحقائق شرح كز الدقائق لعثمان بن على الزيلعى ط/ دار الكتاب

$$
\text { الإسلامي. }
$$

ع-تحفه الفقهاء لعلاء الدين السمرقندى ت و وبه هـــ ط/ دار الكتب العلمية

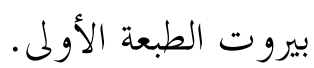

ه-رد المتار على الدر المختار لخمد أمين المعروف بابن عابدين. ط/ دار

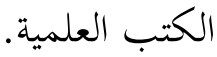




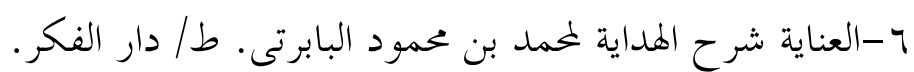

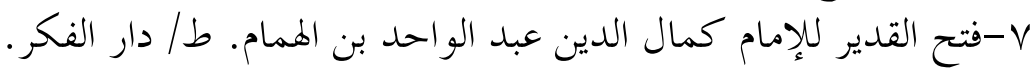

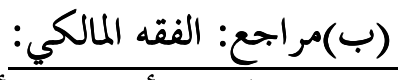

1-بداية البختهد لأبي الوليد أحمد بن بلني: محمد بن رشد الحفيد ت

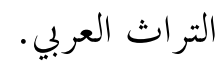

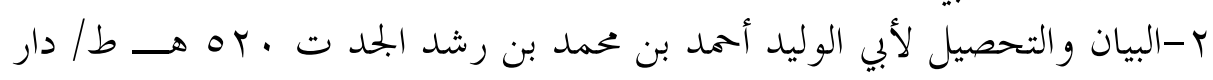

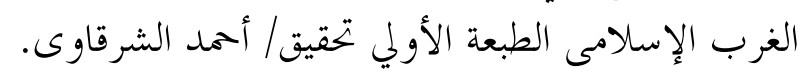

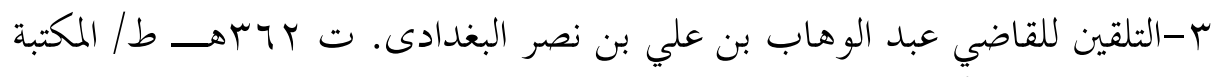
التجارية الأولي تحقيق محمد ثالث عابل سعيد الغاني.

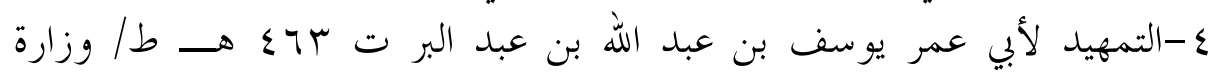

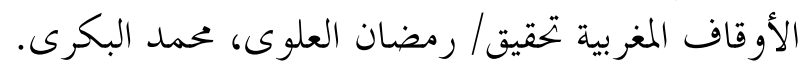

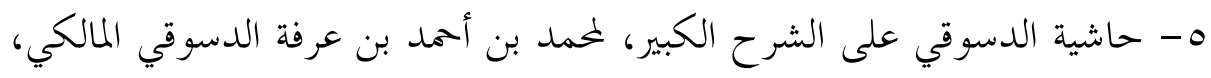

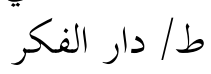

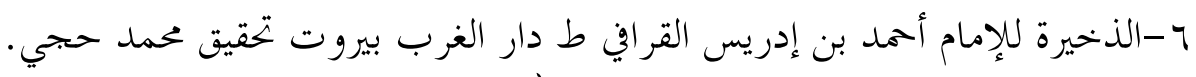

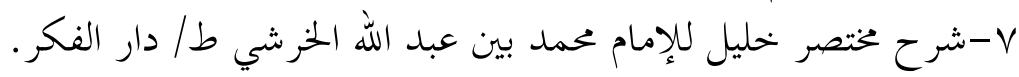

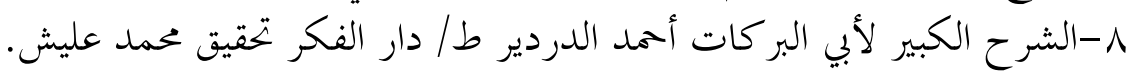

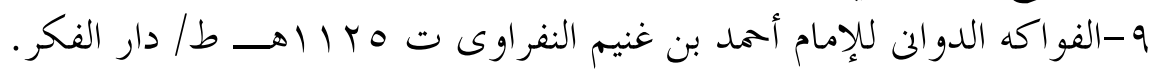

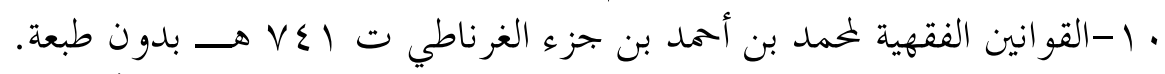

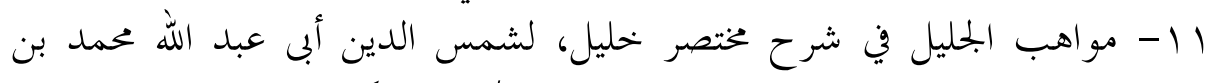

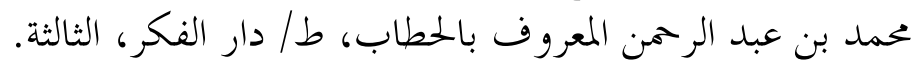

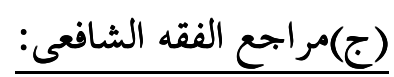

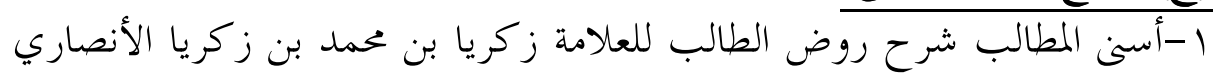

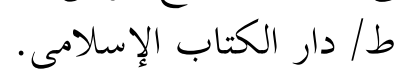

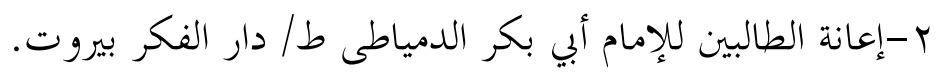

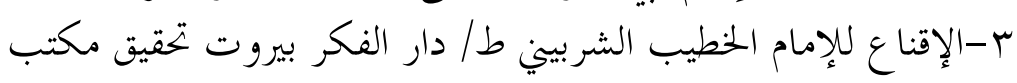

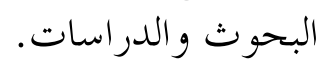
ع - تحفة الختاج في شرح المنهاج، لأحمد بن محمد بن علي بن حجر الهيتمي 
ط/ المكتبة التجارية الكبرى .مصر.

0-حاشية البجيرمى على الخطيب لسليمان بن محمد البجيرمى طا لـ دار الفكر.

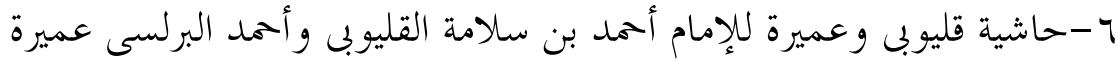
ط/ دار إحياء الكتب العربية. V-حواشي الشرواني على تحفة المحتاج بشرح المنهاج عبد الحمميد الشرواني الناشر دار الفكر

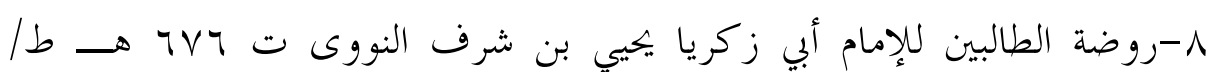

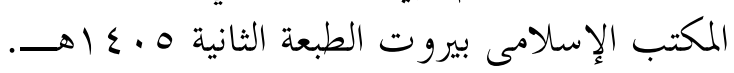

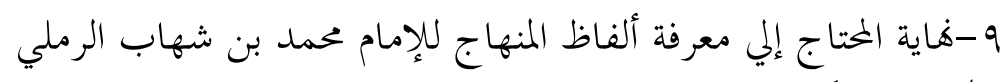
ط/ دار الفكر.

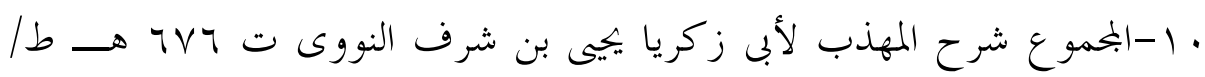

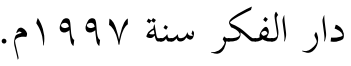
1 - الوسيط في المذهب، لأبى حامد محمد بن محمد الغزالي الطوسي، تحقيق: أحمد

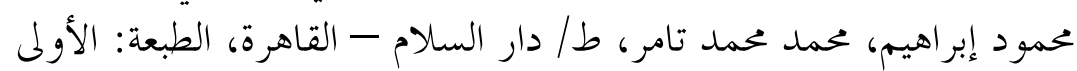
(1) (الإنصاف اجع الفقه الحنبلي: التراث العربي. ب-الروض المربع للإمام منصور بن يوسف البهوتى ت

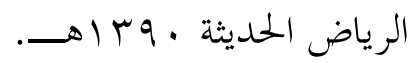

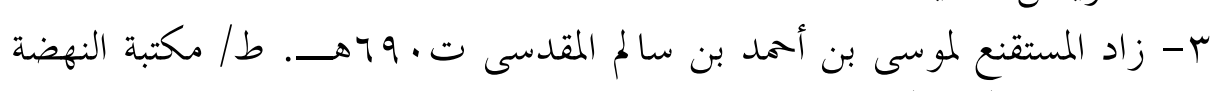
الحمديثة مكة المكرمة.

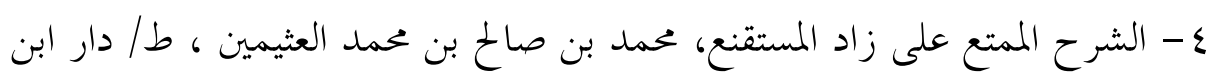

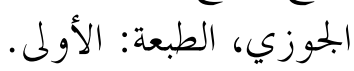

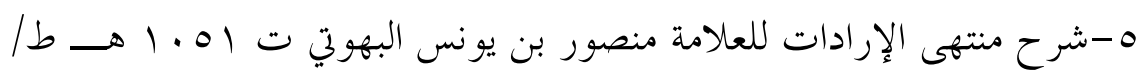

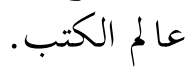
צ-الكافن في فقه ابن حنبل لأبي محمد بن قدامة المقدسى ط/ المكتب الإسلامي 


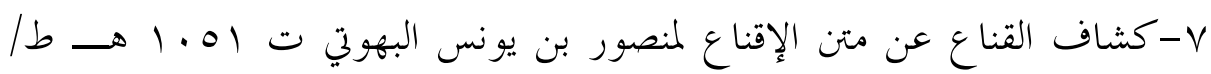
دار الكتب العلمية.

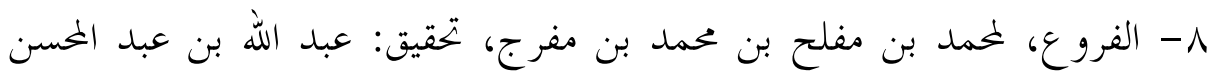

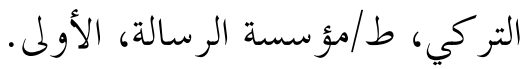

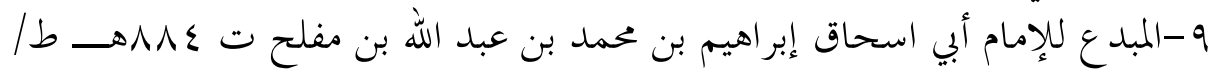

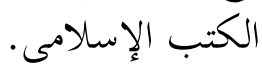
. 1-المغني للإمام ابن قدامة المقدسي. ط دار إحياء التراث الإسلامي.

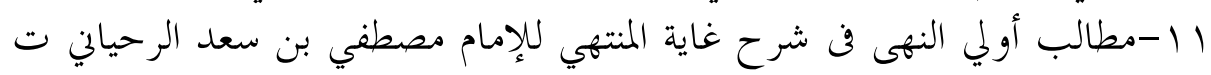

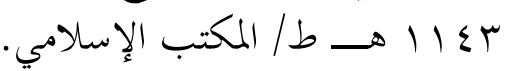

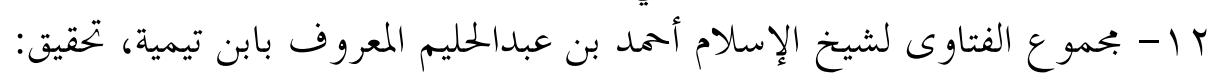

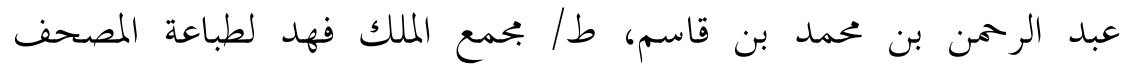

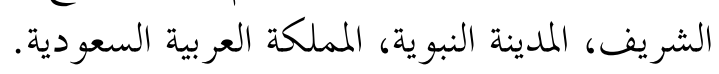

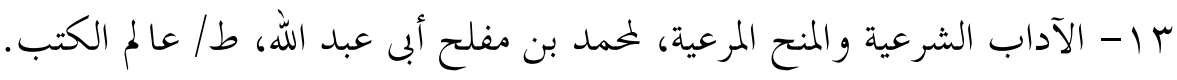

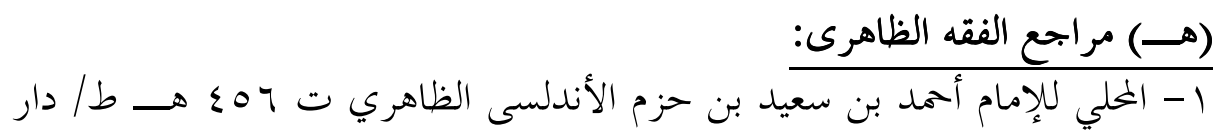

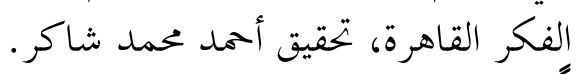

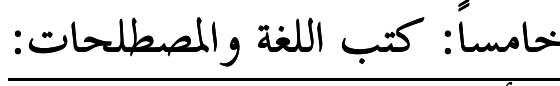

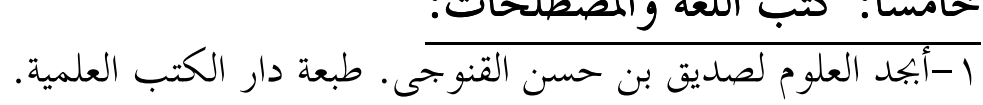

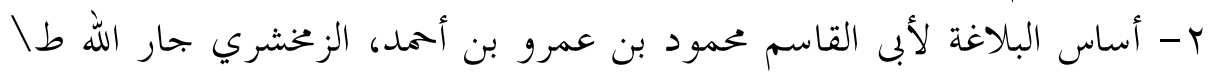

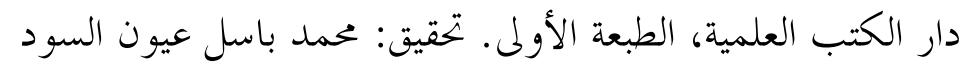

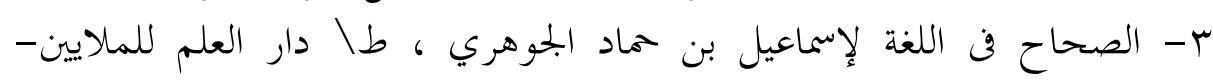

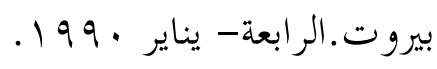

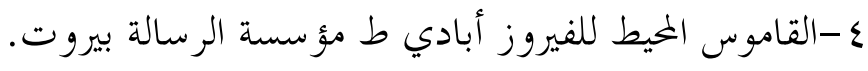

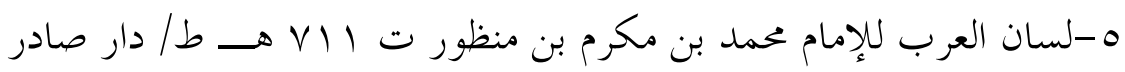

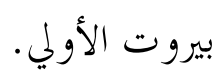

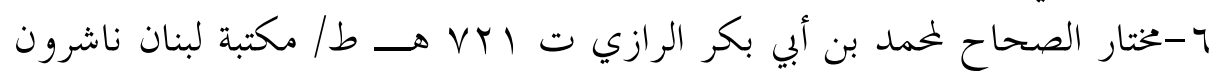

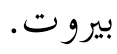


ح-المصباح المنير في غريب الشرح الكبير لأحمد بن علي الفيومي ط المكتبة العلمية.

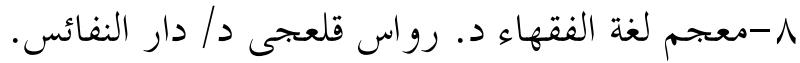

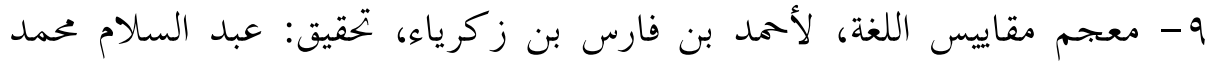

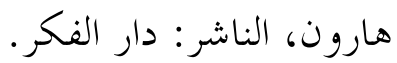

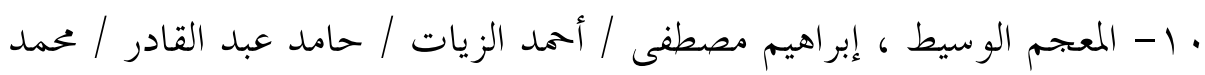

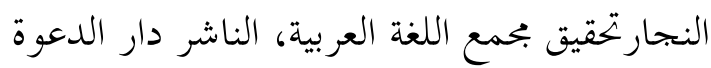

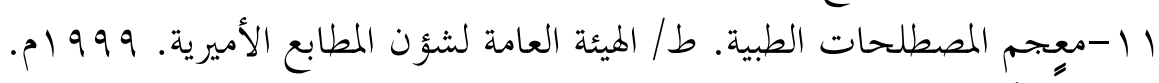

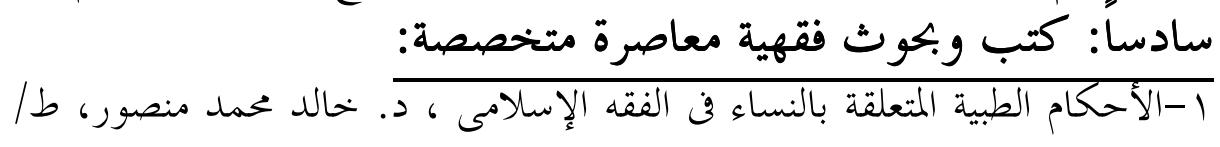
دار النفائس. ץ- أحكام النوازل في الإنحاب، د. محمد بن هائل بن غيلان المدحجى، طا دار كنوز إشبيليا للنشر والتوزيع. الإبكان.

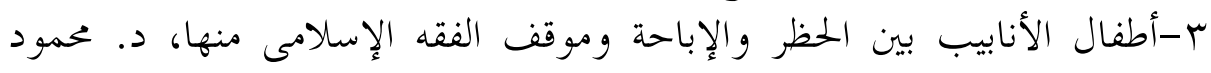

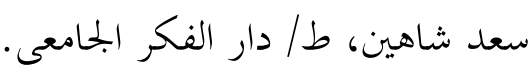

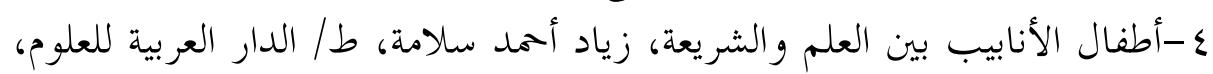

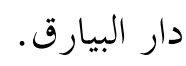

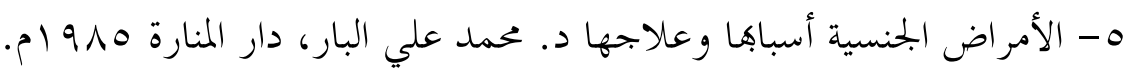

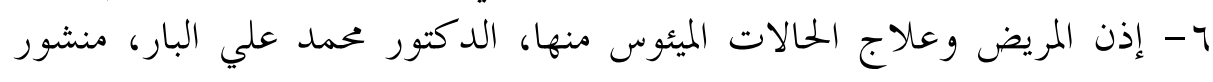
كمجلة البحمع الفقهى.

- V البنوك الطبية البشرية وأحكامها الفقهية ، د. إسماعيل مرحبا، طا دار ابن إبن

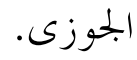

^-بنوك النطف والأجنة دراسة مقارنة في الفقه الإسلامى والقانون الوضعى، د.

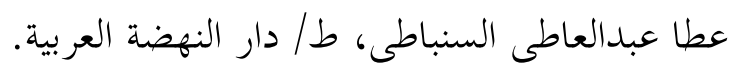

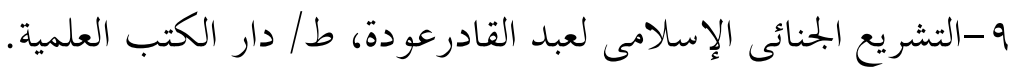

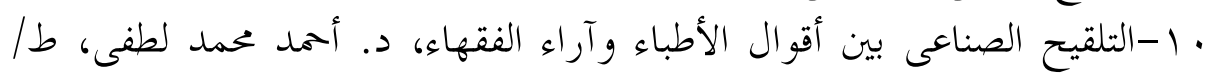

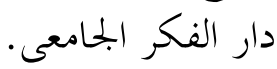


1 ا-التلقيح الصناعي وأطفال الأنابيب، د. محمد على البار، منشور .مجلة المحمع

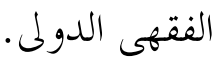

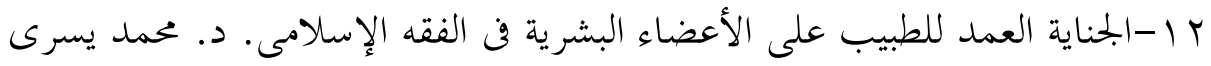

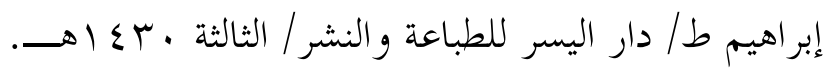

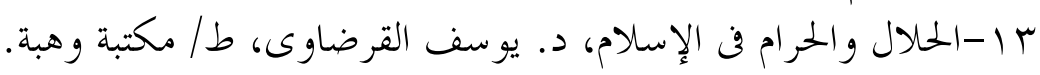

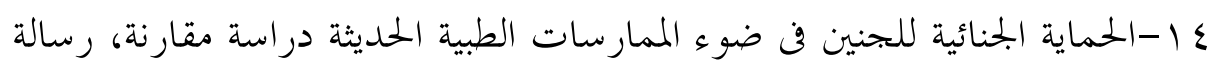
ماجستير كلية الحقوق جامعة الجزائر.

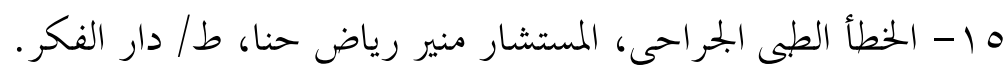

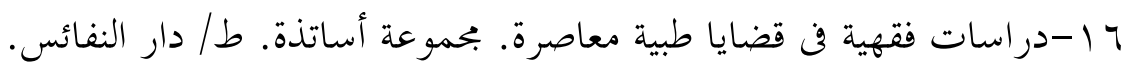

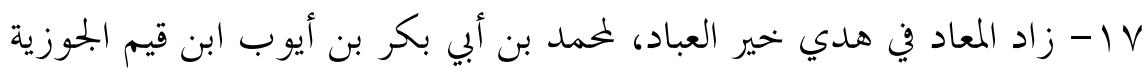

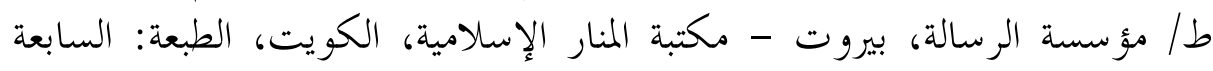
و العشرون.

1 ا-العقم.. الأسباب والعلاج.. نظرة شرعية، مقال للدكتور. محمد بن هائل

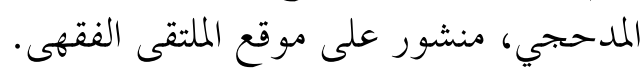

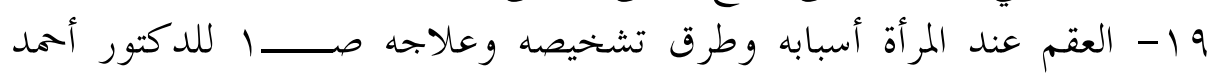

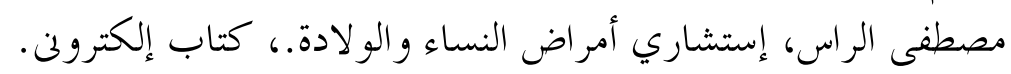

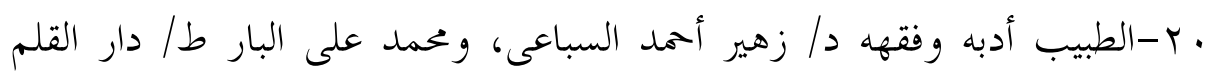
دمشق.

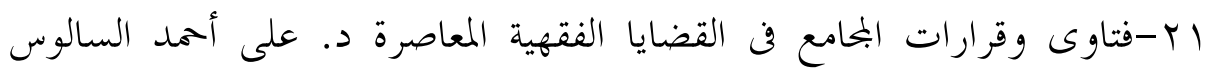

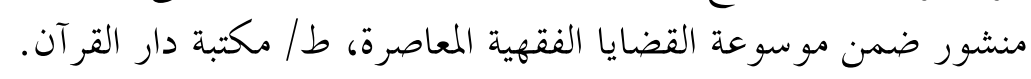

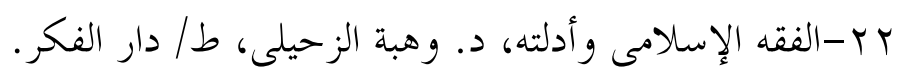

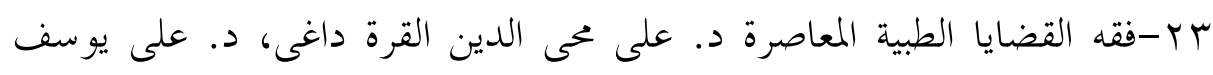
المحمدى. ط/ دار البشائر الإسلامية.

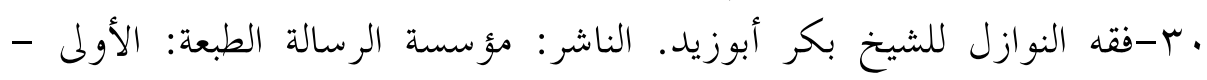

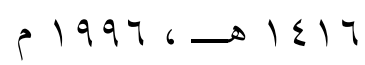

اس-القانون الجنائى والطب الحديث. د أحمد شوقى أبو خطوة. طا دار النهضة العربية. 
العدد الثلاثون - الجزء الأول

r ب-قرارات وتوصيات البحمع الفقهى الإسلامى برابطة العالم الإسلامى. الدورة

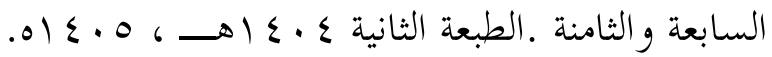

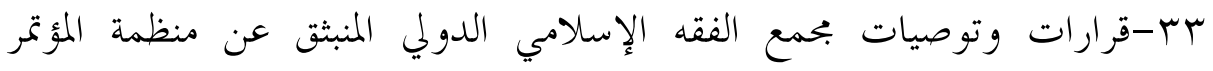

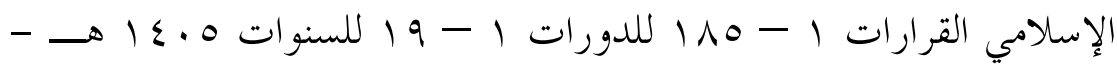
. $\rightarrow 1 \leqslant r$.

ع ب-بحلة البحوث الإسلامية المعاصرة، بحلة إلكترونية.

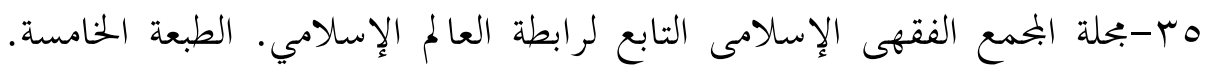
$\rightarrow 1 \leqslant r \leqslant$

بr-بحلة البحمع الفقهى الدولى وهي بحلة معروفة تصدر عن بحمع الفقه الإسلامي

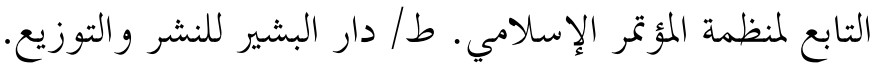
VV

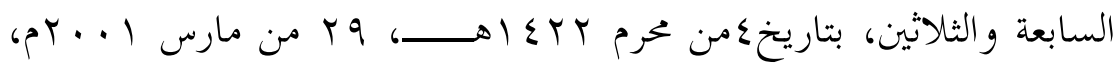

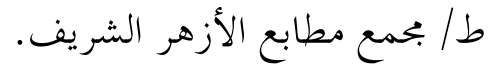

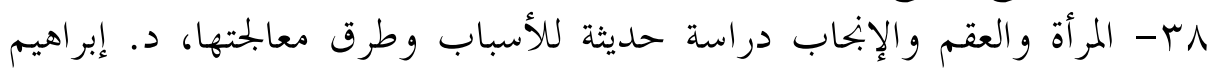

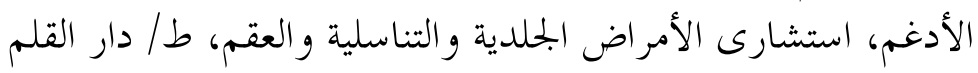

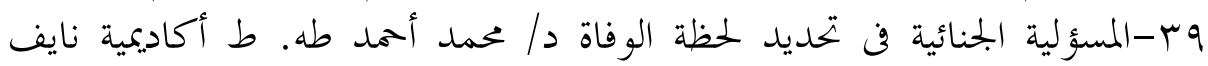

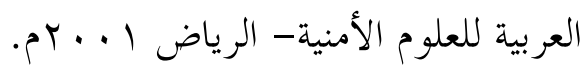

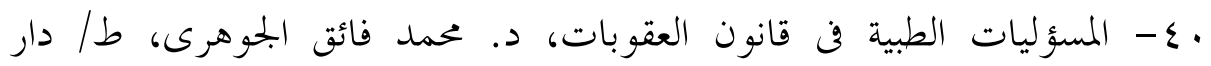

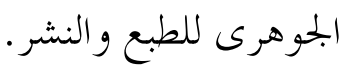

إع-المسؤلية المدنية للطبيب عن الأخطاء الطبية في بحال التلقيح الصناعى، الباحث: بدر محمد الزغيب، جامعة الشرق الأوسط.

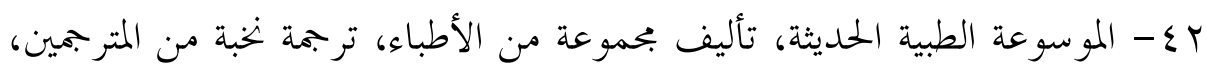
ط/ مؤسسة سجل العرب، الثانية.

وآخر دعوانا أن الحمد لله رب العالمين 66،

$r \leqslant q$ 


\section{فهرب المضوعات}

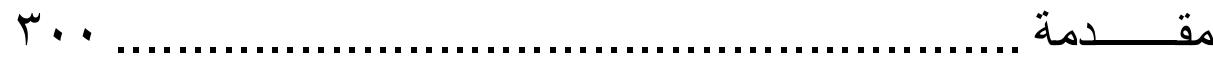

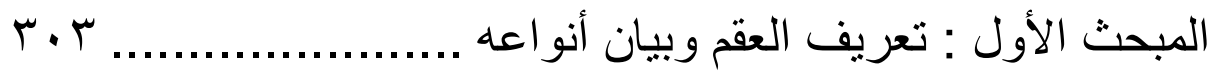

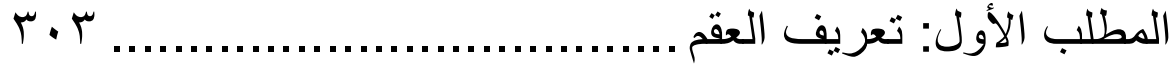

تعريف العقم عند الفقهاء............................................ 0

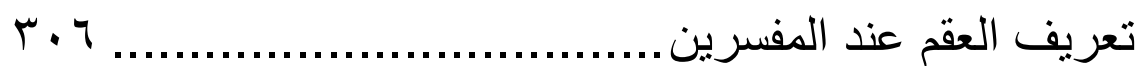

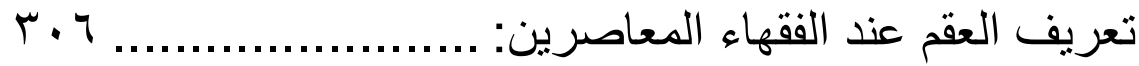

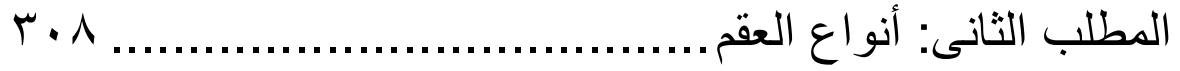

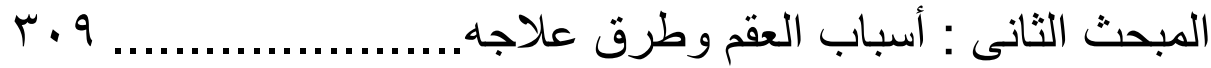

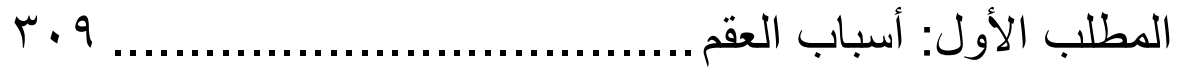

المطلب الثانى: طرق علاج العق.............................................

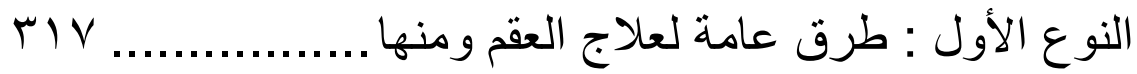

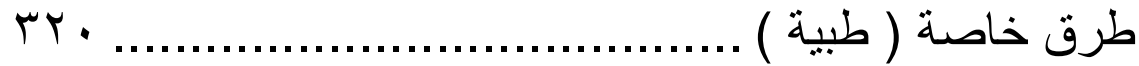

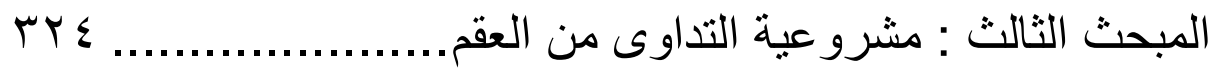

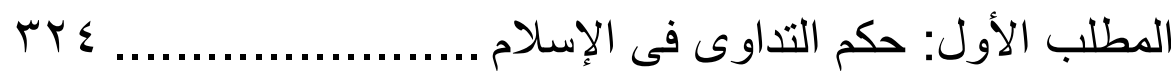

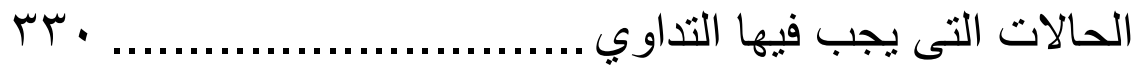

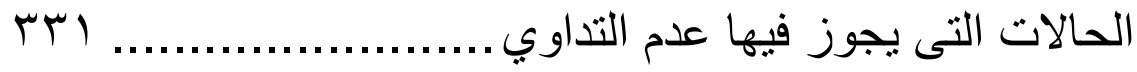

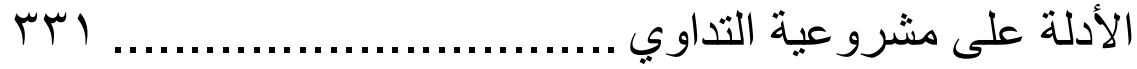

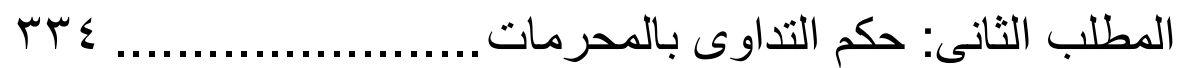

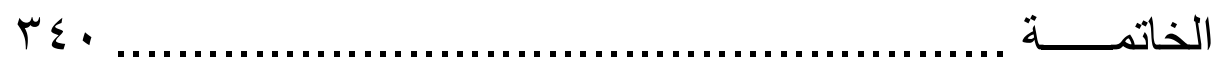

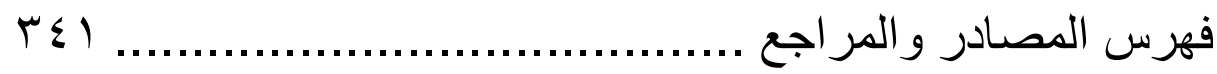

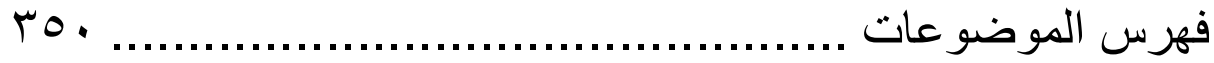

